\title{
Switchgrass and Miscanthus Biomass and Theoretical Ethanol Production from Reclaimed Mine Lands in West Virginia
}

\author{
Steffany M. Scagline
}

Follow this and additional works at: https://researchrepository.wvu.edu/etd

\section{Recommended Citation}

Scagline, Steffany M., "Switchgrass and Miscanthus Biomass and Theoretical Ethanol Production from Reclaimed Mine Lands in West Virginia" (2016). Graduate Theses, Dissertations, and Problem Reports. 6577.

https://researchrepository.wvu.edu/etd/6577

This Thesis is protected by copyright and/or related rights. It has been brought to you by the The Research Repository @WVU with permission from the rights-holder(s). You are free to use this Thesis in any way that is permitted by the copyright and related rights legislation that applies to your use. For other uses you must obtain permission from the rights-holder(s) directly, unless additional rights are indicated by a Creative Commons license in the record and/ or on the work itself. This Thesis has been accepted for inclusion in WVU Graduate Theses, Dissertations, and Problem Reports collection by an authorized administrator of The Research Repository @ WVU. For more information, please contact researchrepository@mail.wvu.edu. 


\title{
Switchgrass and Miscanthus Biomass and Theoretical Ethanol Production from Reclaimed Mine Lands in West Virginia
}

\author{
Steffany M. Scagline \\ Thesis submitted \\ to the Davis College of Agriculture, Natural Resources and Design \\ at West Virginia University \\ in partial fulfillment of the requirements for the degree of \\ Master of Science in \\ Soil Sciences
}

Committee:

Dr. Jeffrey Skousen, Chair

Dr. Thomas Griggs

Dr. James Kotcon

Division of Plant and Soil Sciences

\author{
Morgantown, West Virginia \\ 2016
}

Keywords: Biomass, Bioenergy, Switchgrass, Miscanthus, NIRS

Copyright 2016 Steffany M. Scagline 


\section{ABSTRACT \\ Switchgrass and Miscanthus Biomass and Theoretical Ethanol Production from Reclaimed Mine Lands in West Virginia}

\section{Steffany M. Scagline}

Awareness of environmental issues surrounding current energy practices has opened doors for new possibilities for energy solutions. The 2003 Energy Independence and Security Act mandates that by the year 2022, 16 billion gallons per year of fuel in the United States (U.S.) will be coming from cellulosic bioenergy sources. Herbaceous crop species like switchgrass have been proposed as potential cellulosic crops to meet future energy needs. Switchgrass is a native warm season grass to North America and has been studied on marginal lands and reclaimed mine lands for biomass production capabilities in the U.S. Another species which has been considered for bioenergy production capabilities in Europe, Miscanthus, is also a warm season perennial grass that has high biomass production capabilities. Currently, there are no studies done on the cellulosic bioenergy production capabilities of Miscanthus on reclaimed mine lands in the U.S. This study looks at Miscanthus and switchgrass as two potential cellulosic energy crops on reclaimed mine lands as a post-mining land use option for bioenergy production.

Four studies were conducted on reclaimed mine sites in West Virginia (WV) and Ohio $(\mathrm{OH})$ to determine biomass yield, theoretical ethanol yield (TEY, $\mathrm{L} \mathrm{Mg}^{-1}$ ), and theoretical ethanol production (TEP, $\mathrm{L} \mathrm{ha}^{-1}$ ) of two perennial grass species, switchgrass (Panicum virgatum) and Miscanthus (Miscanthus $x$ giganteus).

The objective of the first study was to determine switchgrass biomass yields as a result of fertilizer and mulch treatments on two reclaimed mine sites (Black Castle and Coal Mac) in WV. Both sites were reclaimed with topsoil over gray overburden material and seeded with 'Cave-inRock' switchgrass. Fertilizer (19-19-19) and mulch combinations were applied at four different rates before seeding in $2011\left(0 \mathrm{~kg}\right.$ fertilizer ha ${ }^{-1}$ and low mulch, $33.6 \mathrm{~kg}$ fertilizer ha ${ }^{-1}$ low and high mulch, and $67 \mathrm{~kg}$ fertilizer ha ${ }^{-1}$ and low mulch) in a randomized block design with five replications. The highest biomass yields $\left(6.5 \mathrm{Mg} \mathrm{ha}^{-1}\right)$ were from plots that received $67 \mathrm{~kg}$ fertilizer ha-1 ${ }^{-1}$ Plots that received no fertilizer had the lowest biomass yields with an average of 3.4 $\mathrm{Mg} \mathrm{ha}^{-1}$.

Study two compared biomass yields of three cultivars of switchgrass (Cave-in-Rock, 'Shawnee', and 'Carthage') on two reclaimed mine sites in WV (Hampshire and Hobet). Hampshire was reclaimed in the early 1990's using topsoil and sewage and paper mill sludges. Hobet was reclaimed in 2006 with no topsoil or soil amendments, only crushed overburden materials. In 2008, each cultivar was planted in 0.4-ha plots with three replications. Across all years the cultivar with the highest biomass yield at Hampshire was Cave-in-Rock $\left(15.1 \mathrm{Mg} \mathrm{ha}^{-1}\right)$. Carthage had the lowest biomass yield at Hampshire at $6.0 \mathrm{Mg} \mathrm{ha}^{-1}$. Hobet produced significantly lower yields than Hampshire with all cultivars. Cave-in-Rock averaged $1.1 \mathrm{Mg} \mathrm{ha}^{-1}$, Carthage averaged 1.3 $\mathrm{Mg} \mathrm{ha}^{-1}$, and Shawnee was the highest at $1.4 \mathrm{Mg} \mathrm{ha}^{-1}$. 
Study three compared switchgrass and Miscanthus yields at three reclaimed mine sites in WV and OH. Two cultivars of switchgrass ('Kanlow' and 'BoMaster') supplied by Enrst Conservation Seeds and two varieities of Miscanthus ('Public' and 'Private') supplied by Mendel Biotechnology were used at Alton, WV. One cultivar of switchgrass (Cave-in-Rock) and one variety of Miscanthus (giant Miscanthus) were used at The Wilds (OH) and MeadWestvaco (WV). Alton was reclaimed in 1985 with less than $15 \mathrm{~cm}$ of soil thickness replaced over mixed overburden and supported herbaceous ground cover for 25 years before switchgrass and Miscanthus were planted in 2010. At The Wilds, soil was composed of dumped overburden material that was graded to approximate contour and seeded in 1988 during reclamation, then our plots of switchgrass and Miscanthus were established in 2013. MeadWestvaco had been reclaimed for 10 years before plots of switchgrass and Miscanthus were established in 2013. Results from Alton showed that both varieties of Miscanthus over all 6 years of sampling was 9.7 $\mathrm{Mg} \mathrm{ha}^{-1}$. Switchgrass production averaged across years and cultivars was $5.8 \mathrm{Mg} \mathrm{ha}^{-1}$. Results from MeadWestvaco and The Wilds showed that switchgrass production at both sites was significantly higher than Miscanthus across years (6.2 and 2.6 Mg ha- ${ }^{-1}$, respectively). The Wilds produced higher yields of both species than MeadWestvaco.

The objective of the fourth study was to evaluate biomass composition, theoretical ethanol yield (TEY, $\mathrm{L} \mathrm{Mg}^{-1}$ ), and theoretical ethanol production (TEP, $\mathrm{L} \mathrm{ha}^{-1}$ ) of switchgrass cultivars and Miscanthus biomass. Compositional analysis was done using near-infrared reflectance spectroscopy (NIRS). Carbohydrates estimated by NIRS were used to determine TEY and multiplied by biomass yields to estimate TEP. Biomass from Alton, MeadWestvaco, The Wilds, and Hampshire were used in this study. TEY were significantly higher for switchgrass than for Miscanthus at Alton, MeadWestvaco, and The Wilds, with ranges of 405 and $450 \mathrm{~L} \mathrm{Mg}^{-}$ ${ }^{1}$. At Alton, TEP was not significantly different between switchgrass and Miscanthus. Switchgrass TEP was significantly higher than Miscanthus $\left(3,600 \mathrm{vs} 1,400 \mathrm{~L} \mathrm{ha}^{-1}\right)$ at The Wilds and MeadWestvaco. Hampshire switchgrass cultivars showed no significant difference for TEY or TEP (average of $413 \mathrm{~L} \mathrm{Mg}^{-1}$ and 12,000 $\mathrm{L} \mathrm{ha}^{-1}$ ). It should be pointed out that the calculations used did not take into account constraints in conversion such as the recalcitrance of lignin and assumed a $100 \%$ conversion efficiency. 


\section{Acknowledgements}

I would like to acknowledge all of the people that made this research possible. First, I would like to thank my chair advisor, Dr. Skousen. Without his funding, constant support, and motivation to "Just keep moving," this would not have been possible. I thank him for his patience, guidance, time, and expert knowledge. This research project has challenged me, but also broadened my interest in reclamation and the importance of this area of research. $\mathrm{He}$ provided me with opportunities that I would not have had otherwise, and for that I am so grateful. I hope that this research will be helpful in any way to the scientific community and the interest in bioenergy.

I would also like to thank Dr. Griggs for all of the time he put into helping me learn and understand every aspect of this research for the past two years. His knowledge and willingness to help students is incredible. I thank him for all of the information he provided me with and the motivation to complete my research. Also, I would like to thank Dr. Kotcon for always steering me in the right direction and supplying me with a wealth of knowledge and advice when I was in need.

Thank you to my incredible family, who supported me throughout my life and this journey through graduate school. Their constant love and encouragement has helped shape me into the person I am today. Thank you to Sloan for always providing me with constant companionship and support.

I would also like to thank my friends and other graduate students for helping me with field work, studying, and sharing our frustrations and successes throughout this journey. Their help will never be forgotten.

A special thank you to the NewBio Consortium for providing funding for this research project, without this funding I would not have been able to accomplish my Masters and learn so much from my time here. 


\section{Table of Contents}

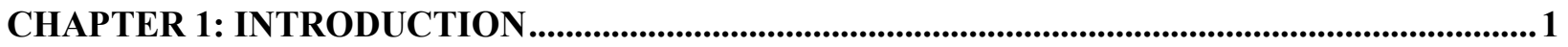

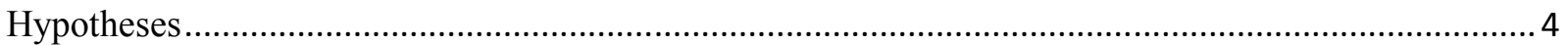

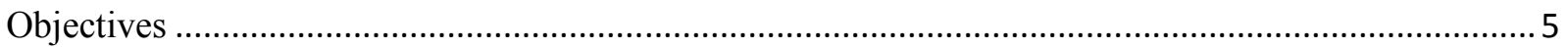

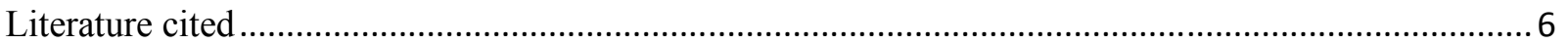

CHAPTER 2: RESPONSE OF SWITCHGRASS YIELD TO FERTILIZER TREATMENTS ON

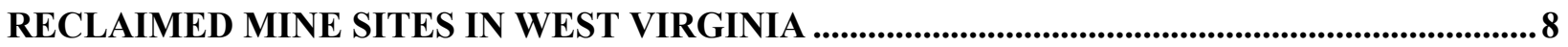

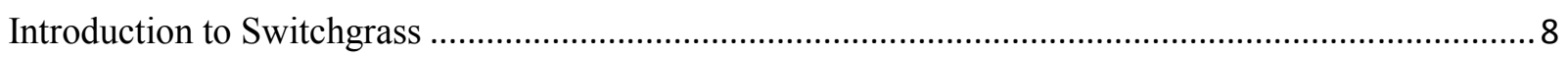

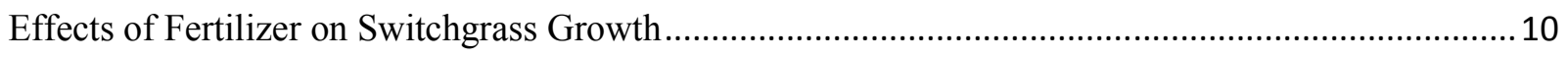

Nitrogen Use Efficiency (NUE) of Switchgrass .............................................................................. 11

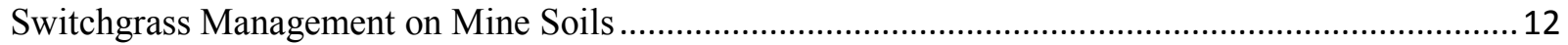

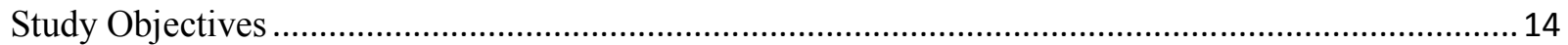

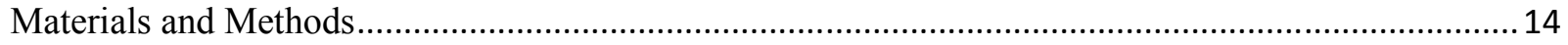

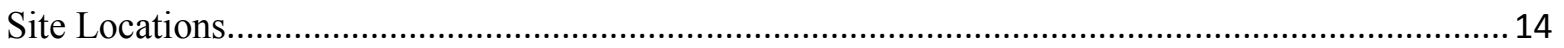

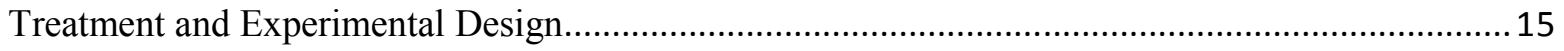

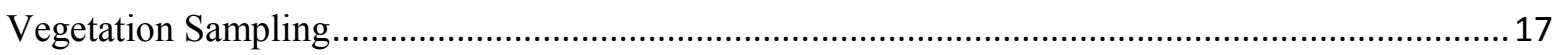

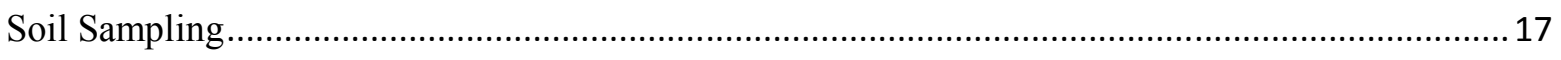

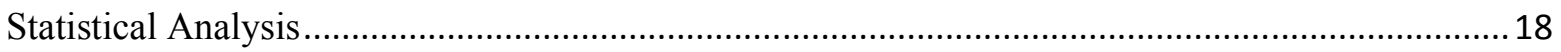

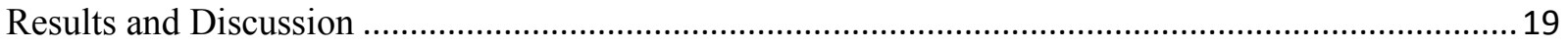

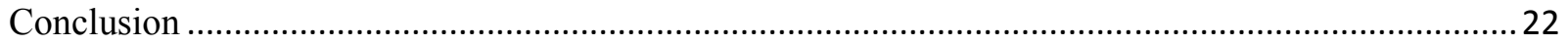

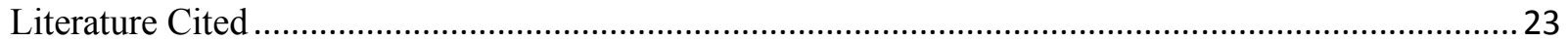

CHAPTER 3: YIELDS OF THREE SWITCHGRASS CULTIVARS GROWN ON RECLAIMED

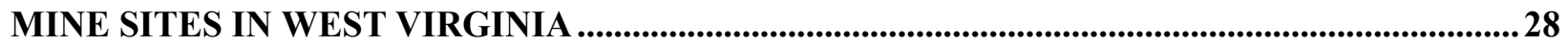

Introduction to Lowland and Upland Switchgrass Cultivars ......................................................... 28

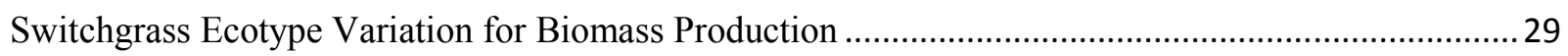

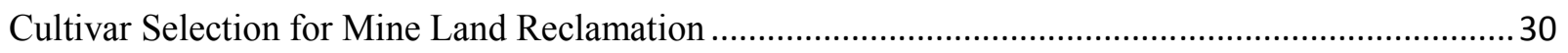

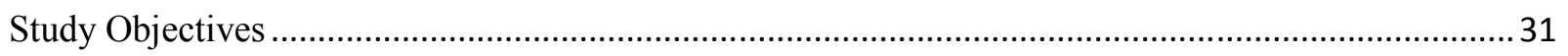

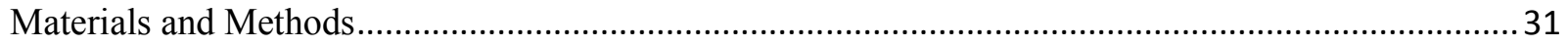

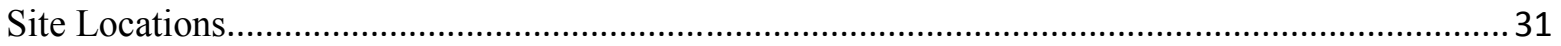

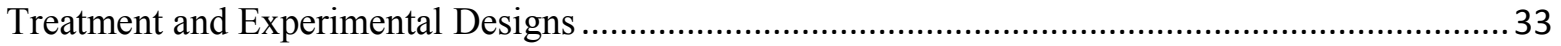

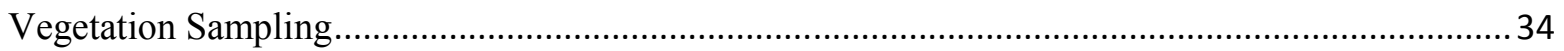

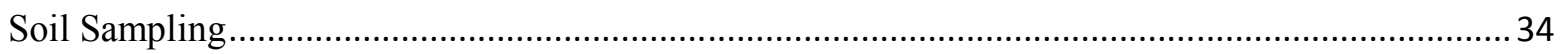

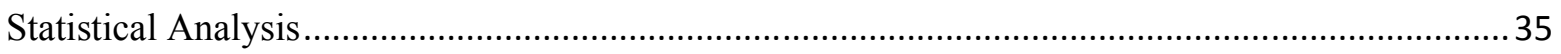




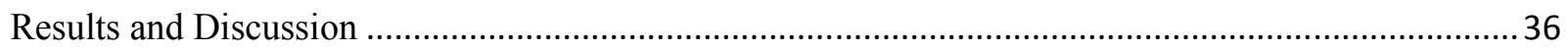

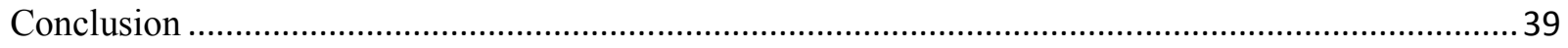

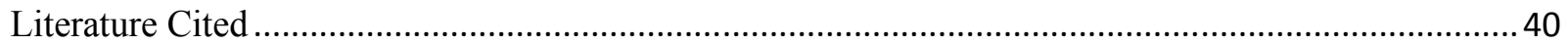

CHAPTER 4: BIOMASS YIELDS OF MISCANTHUS COMPARED TO BIOMASS YIELDS OF SWITCHGRASS GROWN ON RECLAIMED MINE SITES IN WEST VIRGINIA AND OHIO.44

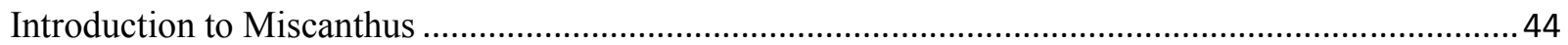

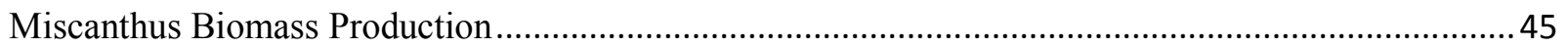

Miscanthus Management on Marginal Soils............................................................................. 47

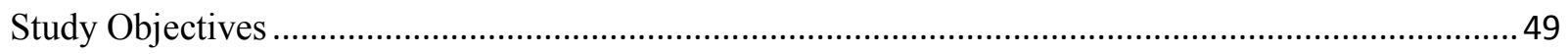

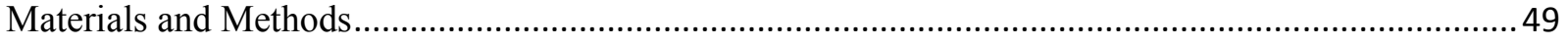

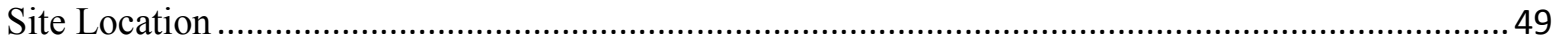

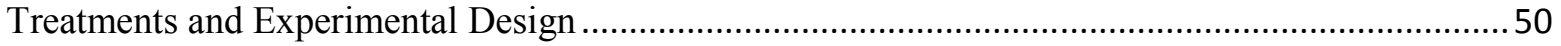

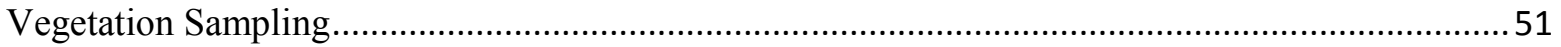

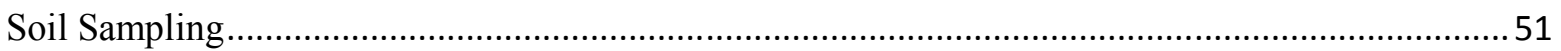

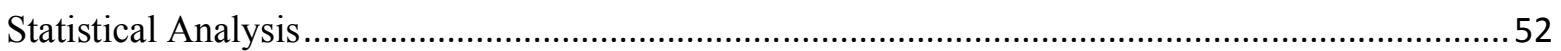

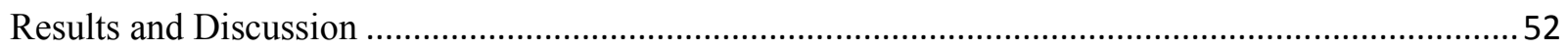

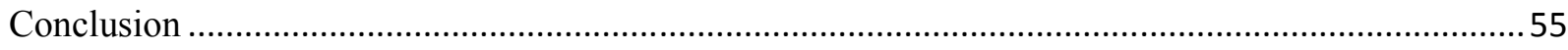

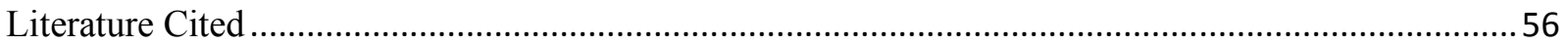

CHAPTER 5: THEORETICAL ETHANOL YIELD (L MG-1) AND THEORETICAL ETHANOL PRODUCTION (L HA ${ }^{-1}$ ) FROM SWITCHGRASS AND MISCANTHUS ON RECLAIMED MINE

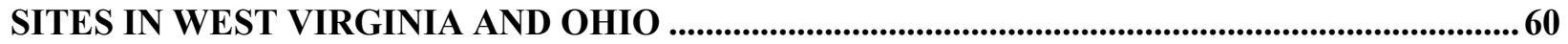

Introduction to Near-Infrared Reflectance Spectroscopy ..................................................................60

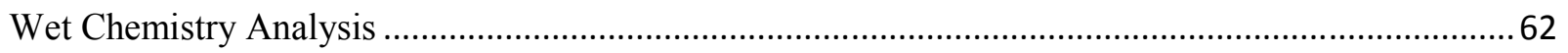

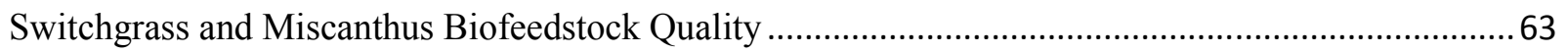

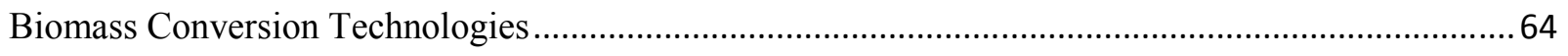

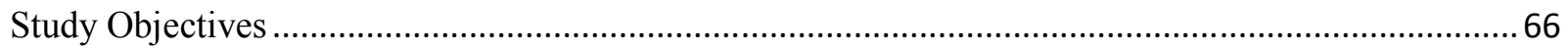

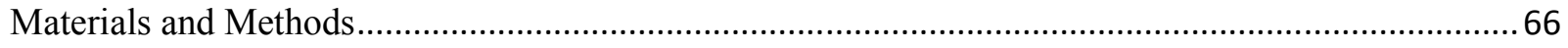

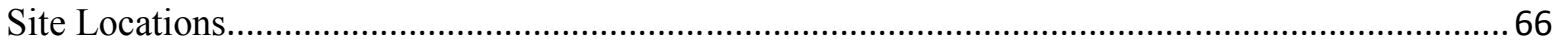

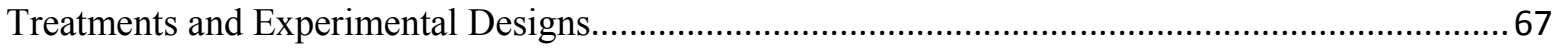

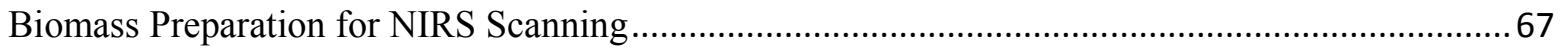

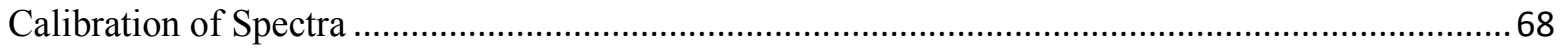

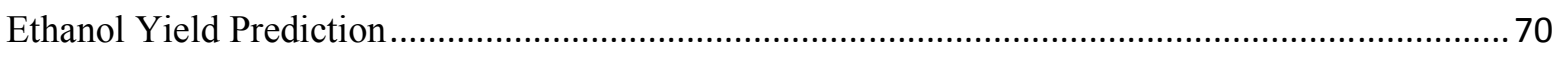

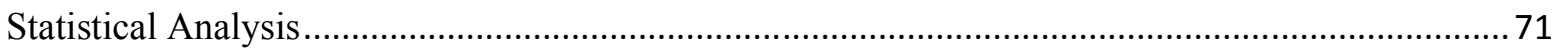

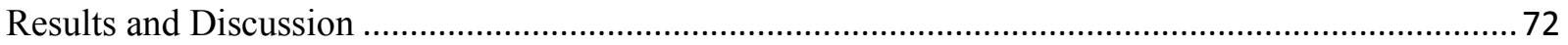




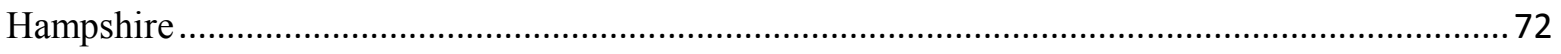

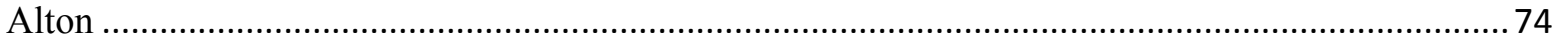

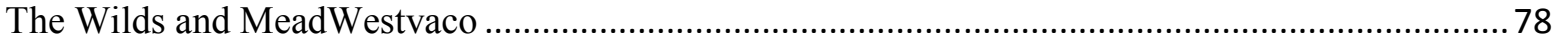

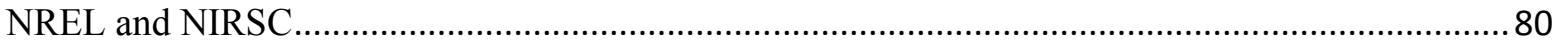

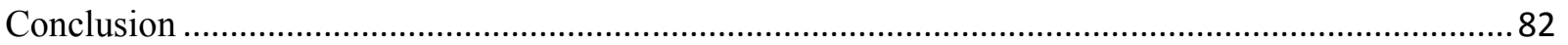

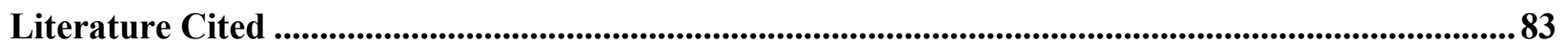




\section{List of Tables}

Table 2.1: Coal Mac and Black Castle split-plot ANOVA with repeated measures statistical design.

Table 2.2: Chemical and physical soil characteristics for each site for 2015.

Table 2.3: Values of extractable soil nutrients using Mehlich 1 solution at Black Castle and Coal Mac for 2015.

Table 2.4: Black Castle and Coal Mac biomass yields for main effect of site, treatment, year, and interaction between treatment and year.

Table 3.1: Hampshire and Hobet ANOVA with repeated measures statistical design.

Table 3.2: Chemical and physical soil characteristics for each site for 2015.

Table 3.3: Values of extractable soil nutrients using Mehlich 1 solution at Hobet and Hampshire or 2015.

Table 3.4: Displays switchgrass cultivar biomass yields over 2009 to 2015 at Hampshire and Hobet.

Table 3.5: Hampshire and Hobet statistical significance of biomass yields for main effect of site, cultivar, and year.

Table 4.1: Chemical and physical soil characteristics averaged for each site for 2015.

Table 4.2: Values of extractable soil nutrients using Mehlich 1 solution for 2015.

Table 4.3: Alton statistical significance biomass yields for main effect of species, cultivar, and year.

Table 4.4: MeadWestvaco and The Wilds statistical significance biomass yields for main effect of site, species, and year.

Table 5.1: Compositional traits predicted with NIRS.

Table 5.2: Methods and carbohydrates used in predicting theoretical ethanol yield (TEY, L Mg1) and theoretical ethanol production (TEP, L ha-1) on reclaimed surface mines.

Table 5.3: Compositional values for Hampshire from switchgrass biomass samples clipped in 2015.

Table 5.4: Select forage quality traits for Hampshire.

Table 5.5: Theoretical ethanol yield (TEY, $\mathrm{L} \mathrm{Mg}^{-1}$ ) and theoretical ethanol production (TEP, L $\mathrm{ha}^{-1}$ ) from Hampshire for biomass clippings in year 2015 using the Method 2 prediction equation (Dien et al., 2010).

Table 5.6: Compositional values for biomass clippings from years 2014 and 2015 from Alton. 
Table 5.7: Forage quality traits for biomass clippings from years 2014 and 2015 from Alton.

Table 5.8: Theoretical ethanol yield (TEY, $\mathrm{L} \mathrm{Mg}^{-1}$ ) and Theoretical ethanol production (TEP, L $\mathrm{ha}^{-1}$ ) from Method 2 for biomass clippings from 2014 and 2015 from Alton.

Table 5.9: Compositional values for switchgrass and Miscanthus biomass clippings from 2015 from MWV and The Wilds.

Table 5.10: Forage quality traits for switchgrass and Miscanthus biomass clippings from 2015 for MWV and The Wilds.

Table 5.11: Theoretical ethanol yield (TEY, $\mathrm{L} \mathrm{Mg}^{-1}$ ) and theoretical ethanol production (TEP, $\mathrm{L}$ $\mathrm{ha}^{-1}$ ) for Method 2 for switchgrass and Miscanthus biomass clipped from 2015 from MWV and The Wilds.

Table 5.12: Carbohydrate constituents, theoretical ethanol yield (TEY, $\mathrm{L} \mathrm{Mg}^{-1}$ ) and theoretical ethanol production (TEP, $\mathrm{L} \mathrm{ha}^{-1}$ ) from biomass clippings from 2014 and 2015 from Alton and from 2015 from MWV and The Wilds comparing NREL and NIRSC. 


\section{List of Figures}

Figure 2.1: Schematic map showing Black Castle and Coal Mac sites in West Virginia.

Figure 2.2: Schematic map of research blocks, sub-plots, and sampling points at Coal Mac

Figure 2.3: Schematic map of research blocks, sub-plots, and sampling points at Black Castle

Figure 2.4: Displays treatment by year interaction between biomass (Mg ha-1) averaged over site per year.

Figure 3.1: Schematic map showing Hampshire and Hobet sites.

Figure 3.2: Schematic map of Hampshire displaying example sample points and plot layout.

Figure 3.3: Schematic map of Hobet displaying example sample points and plot layout.

Figure 3.4: Displays switchgrass cultivar averages from year 2009 to 2015 at Hampshire and Hobet.

Figure 5.1: Simplified NIRS example. 


\section{CHAPTER 1: INTRODUCTION}

Surface coal mining in Appalachia dates from the early 1900s (Plass, 2000). Surface mining removes overburden to expose coal seams near the earth's surface. Before current rules for reclamation were enacted, attempts to reclaim these disturbances were minimal. The Appalachian region of the United States, especially West Virginia (WV), became more impacted by coal mining during the 1950s and 1960s when larger equipment and technologies permitted mining to deeper levels, which disturbed greater land areas (Plass, 2000). In response to the drastic disturbances and environmental impacts, law-makers realized the need for strict reclamation regulations that would return disturbed land to productivity equal to or exceeding that prior to its disturbance (Plass, 2000).

The Surface Mining Control and Reclamation Act (SMCRA) of 1977 required companies to complete an environmental impact assessment of the area being proposed for mining. Included in SMCRA is the responsibility of the mining company to establish a post-mining land use that is acceptable to the land owner, will minimize impacts to the environment, and is compatible with surrounding unmined land uses. While there are a number of post-mining land uses to choose from, careful selection of the most appropriate land use is necessary to provide income opportunities for landowners and to prevent environmental degradation and pollution. More than $70 \%$ of surface-mined land is reclaimed to pasture and hay land, but forestry has been selected as a post-mining land use on more areas recently. Another potential use for reclaimed lands is the growth and production of dedicated bioenergy crops as feedstocks for ethanol and combustion.

It is estimated that 4.9 million ha have been affected by surface mining activities in WV, eastern Kentucky, and a few counties in Tennessee (U.S. EPA, 2005). Much of the land that has been reclaimed to pasture and hay land during past decades could be converted to more 
economically productive alternatives such as bioenergy crops that would not require low maintenance. Current operations could also reclaim the land to support bioenergy crop production.

With the increase in global awareness of climate change, the need for alternative energy sources is becoming increasingly important. Although there are numerous alternatives to fossil fuels, a sustainable ethanol production system works well with existing automobile standards, is renewable,reduces dependence on foreign oil (Mitchell et al., 2008), and could provide economic returns to rural areas.

In 2014, the US consumed an average of 19 million barrels of oil per day (U.S. EIA, 2014). In 2012, the United States used 838,000 barrels of ethanol per day for transportation fuels (U.S. EIA, 2014), amounting to less than 5\%. Ethanol cannot currently be used as a sole source fuel in any engine and the maximum allowable percentage of ethanol for non-flex cars made before 2001 is $10 \%$ (E10) (U.S. EIA, 2012). Flex-fuel cars can use up to $85 \%$ ethanol in the fuel.

The Energy Independence and Security Act of 2007 set specific standards to help reduce dependence on fossil fuels and to increase use of alternative energy sources that would reduce emissions related to global climate change (U.S. EIA, 2014). By the year 2022, the goal established by Congress is to increase renewable fuel production to 36 billion gallons (or 0.9 billion barrels or about $15 \%$ of the total fuel). The most widely-used biofuel currently comes from conversion of corn grain (Zea mays L.) to ethanol. With a demand for increased agricultural production to meet the food needs of a growing population, the continued use of corn grain as a bioenergy feedstock is being questioned. Corn is an annual crop that has large soil nutrient requirements and grows primarily on agricultural lands, all of which make it an environmentally and economically undesirable choice for fuel production (Hahn-Hagerdal et al., 2006). However, 
recent technologies are using corn stover for cellulosic ethanol production in addition to grainbased ethanol. This still takes up land that could be used to grow other agricultural crops for food.

Other crops have been evaluated for bioenergy production capabilities that have lower cultural inputs and management requirements. Switchgrass (Panicum virgatum L.) and Miscanthus (Miscanthus x giganteus J.M. Greef \& Deuter ex Hodkinson \& Renvoize) are warmseason $\left(\mathrm{C}_{4}\right)$ perennial grasses that provide biofuel production capabilities due to their ability to produce large amounts of biomass on marginal land such as reclaimed mine lands (Skousen et al., 2013).

Multiple studies have been done in the United States on the biofuel capabilities of switchgrass on reclaimed mine lands. However, there are currently no published studies done on the biofuel capabilities of Miscanthus on reclaimed mine sites in the US. European studies have shown Miscanthus to be a promising alternative to current biofuel crops because it is capable of producing yields double that of the current "model" biofuel crop, switchgrass (Price et al., 2004; Christian et al., 2008). Miscanthus could be able to produce greater amounts of biomass yields and therefore have greater cellulosic ethanol potential on the same amount of land as switchgrass, making it a more economically beneficial option to meeting current mandates. 


\section{Hypotheses}

1. In 2011, to determine the effect of fertilizer and mulch treatments on switchgrass biomass yields on reclaimed mine sites, multiple combinations of fertilizer (19-19-19) and mulch treatments were applied at two reclaimed mine sites. Preceding research done at these sites have shown that the highest fertilizer application $\left(67 \mathrm{~kg}_{\text {fertilizer ha }}{ }^{-1}\right)$ resulted in the highest biomass yields. Due to this trend, biomass yields from the most recent collection will also be the highest yielding for the highest fertilizer treatment due to the initial increase in nutrients from fertilization during establishment in 2011.

2. Preceding research done on switchgrass cultivar, Cave-in-Rock, has shown higher biomass yields over the past 8 years than other cultivars researched (Shawnee and Carthage). Due to this trend, Cave-in-Rock will continue to produce higher biomass yields than Shawnee and Carthage on the reclaimed mine sites, Hampshire and Hobet.

3. Literature on Miscanthus (Miscanthus $\mathrm{x}$ giganteus) has shown that this species is capable of producing high biomass yields on agricultural and marginal lands in Europe. Research has also shown Miscanthus to produce higher biomass yields than switchgrass on agricultural lands. Because of these findings, Miscanthus will also produce higher biomass yields than switchgrass on reclaimed mine sites.

4. Biomass composition and theoretical ethanol yield (TEY, $\mathrm{L} \mathrm{Mg}^{-1}$ ) will not differ significantly between Miscanthus and switchgrass due to the similarities between their nutrient-use and nutrient-cycling patterns.

5. Because Miscanthus will likely produce greater yields of biomass based on other studies, theoretical ethanol production (TEP, $\mathrm{L} \mathrm{ha}^{-1}$ ) will be significantly higher for Miscanthus than switchgrass on reclaimed mine sites. 


\section{Objectives}

Fertilizer (19-19-19) and mulch treatments were applied in 2011 before plantings began. Treatments were applied and biomass was collected previously by students for research purposes (Brown et al., 2014). To test hypothesis 1, biomass yields of Cave-in-Rock switchgrass will be collected and tested at Coal Mac and Black Castle sites after the $4^{\text {th }}$ and $5^{\text {th }}$ year of establishment to follow research previously done at these sites.

To test hypothesis 2, biomass yields of switchgrass cultivars Cave-in-Rock, Shawnee, and Carthage will be determined at Hampshire and Hobet sites after the $7^{\text {th }}$ and $8^{\text {th }}$ year of establishment. Previous years (2009-2014) of biomass yields were sampled for research purposes (Brown et al., 2014). The objective was to follow the most recent biomass yields and findings.

To test hypothesis 3, biomass yields of cultivars of switchgrass (Kanlow and BoMaster) and varieties of Miscanthus (Public and Private) will be compared after the $5^{\text {th }}$ and $6^{\text {th }}$ year of establishment at Alton. At MeadWestvaco and The Wilds reclaimed mine sites, biomass yields of Cave-in-Rock switchgrass and Miscanthus (Miscanthus $x$ giganteus) will be compared after the $3^{\text {rd }}$ and $4^{\text {th }}$ year of establishment. Biomass yields from these sites were also previously studied for research purposes (Skousen et al., 2013).

To test hypothesis 4 and 5, biomass composition from Hampshire, Alton, MeadWestvaco, and The Wilds will be analyzed using NIRS to predict biomass composition to determine TEY. Biomass yields (determined in objective 3) will be multiplied by TEY predictions to calculate TEP for each species at those sites. 


\section{Literature cited}

Brown, C. 2014. Biomass production, composition, and ethanol potential of switchgrass grown on reclaimed surface mines in West Virginia. M.S. thes., West Virginia Univ., West Virginia.

Christian, D.G., A.B. Riche, and N.E. Yates. 2008. Growth, yield and mineral content of Miscanthus $\times$ giganteus grown as a biofuel for 14 successive harvests. In Crop Prod 28: 320-327.

Hahn-Hagerdal, B., M. Galbe, M.F. Gorwa-Grauslund, G. Liden, and G. Zacchi. 2006. Bioethanol- The fuel of tomorrow from the residues of today. TrendsBiotechnol 24: 549-556

Marra, M., T. Keene, J. Skousen, T. Griggs. 2013. Switchgrass yield on reclaimed surface mines forbioenergy production. J. Environ. Qual. 42: 696-703.

Mitchell, R., K.P. Vogel, and G. Sarath. 2008. Managing and enhancing switchgrass as a bioenergy feedstock. Biofuel Bioprod Bior 2: 530-539.

Plass, W.T. 2000. History of surface mining reclamation and associated legislation. In: Reclamation of drastically disturbed lands. In: Barnhisel, R.I., R.G. Darmody, and W.L. Daniels, (Eds.). American Society of Agronomy, Crop Science Society of America, Soil Science Society of America, Monograph 41: 1-20.

Price, L., M. Bullard, H. Lyons, S. Anthony, and P. Nixon. 2004. Identifying the yield potential of Miscanthus x giganteus: An assessment of the spatial and temporal variability of M. x giganteus biomass productivity across England and Wales. Biomass Bioenerg 26: 3-13. 
Skousen, J., T. Keene, M. Marra, and B. Gutta. 2013. Reclamation of mined land with switchgrass, Miscanthus, and Arundo for biofuel production. J. Am. Soc. Mining Recl. 2: $177-191$.

U.S. Energy Information Administration (US EIA). 2012. Biofuels Issues and Trends. http://www.eia.gov/biofuels/issuestrends/. Department of Energy, Washington, DC.

U.S. Energy Information Administration (US EIA). 2014. Analysis and Projections. http://www.eia.gov/tools/faqs/faq.cfm?id=33\&t=6. Department of Energy, Washington, DC. Accessed September, 2015.

U.S. Environmental Protection Agency (US EPA). 2005. Mountaintop Mining/Valley Fills in Appalachia. Final Programmatic Environmental Impact Statement. EPA Region 3. Philadelphia, PA. EPA 9-03-R-05002. 


\section{CHAPTER 2: RESPONSE OF SWITCHGRASS YIELD TO FERTILIZER TREATMENTS ON RECLAIMED MINE SITES IN WEST VIRGINIA}

\section{Introduction to Switchgrass}

Switchgrass (Panicum virgatum) is a warm-season perennial grass (Waller and Lewis, 1979) that is native to North America. Switchgrass has been seeded in pastures and rangeland in pure stands and mixtures in the Great Plains for more than 60 years (Vogel, 2004). In the past 20 years, it has become more prevalent as a pasture grass in the central and eastern USA (Vogel, 2004). Switchgrass grows 0.5 to $3 \mathrm{~m}$ tall and forms a dense sod over time (Vogel, 2004). Switchgrass has a thick rooting system that can reach depths of $2.5 \mathrm{~m}$ (Hopkins, 1951; Weaver and Darland, 1949), which can help break up compacted soils and increase water infiltration to increase production capability for future uses (Shrestha and Lal, 2009). Another benefit of switchgrass' extensive root system is the potential to sequester significant amounts of carbon (C) in the soil profile (Garten and Wullschleger, 2000; Liebig et al., 2008).

As it dispersed from tropical origins across Central and North America over time, various populations came to genetic-ecologic equilibrium in many diverse niches (Parrish and Fike, 2005), resulting in distinct lowland and upland ecotypes. Like the name states, upland and lowland ecotypes were named due to the association with where that specific ecotype inhabited (Casler, 2012). Lowland varieties are taller, have coarser stems and leaves, have a more bunchtype growth, grow better in deep moist soils, and may be more productive, while upland varieties tend to be better adapted to shallower soils and drier sites (Parrish and Fike, 2005; Casler, 2012).

Switchgrass uses a C4 photosynthetic pathway which allows it to use water, light energy, and nitrogen $(\mathrm{N})$ more efficiently as well as having a higher tolerance to heat and water stress (Parrish and Fike, 2005) than plants with the C3 photosynthetic pathway. As a perennial species it will senesce and store nutrients over winter. This translocation of nutrients from aboveground 
tissues to crowns and roots in late fall provides the plant with stored carbohydrates and other nutrients that it uses for regrowth in the spring. Minimal concentrations of micro and macronutrients in aboveground tissue are optimal for the use of biomass for ethanol because the presence of certain elements such as nitrogen $(\mathrm{N})$ in biomass can negatively affect biomass digestion, fermentation, or combustion (Yang et al., 2009). Another benefit to low nutrient content in aboveground biomass is that it minimizes nutrient removal off site since switchgrass is generally harvested after senescence and after nutrients have been translocated into crowns and roots.

The stem bases, roots, and rhizomes are the primary sites of nonstructural carbohydrate storage, and starch is the primary and most dynamic nonstructural carbohydrate stored in these tissues (Smith, 1975; Vogel, 2004). Total nonstructural carbohydrate (TNC) concentrations in the stem bases of unharvested plants are greatest at the beginning and end of the growing season (Vogel, 2004). The cell walls are comprised mainly of cellulose and hemicellulose which contain simple sugars such as glucose, xylose, mannose, galactose, and arabinose that are fermented to produce ethanol (Vogel, 2004).

Switchgrass has become a "model" bioenergy feedstock for cellulosic ethanol production because of its ability to produce large quantities of biomass on marginal soils with low soil fertility. Studies have shown switchgrass stands can produce average annual biomass yields of 5.2 to $11.1 \mathrm{Mg}$ dry matter (DM) ha ${ }^{-1}$ when grown on marginal lands in the northern Great Plains (Schmer et al., 2008). Marginal lands share properties similar to reclaimed surface mines. The potential ability of switchgrass to produce high biomass yields on marginal lands may suggest that it is capable of producing similar results on reclaimed mine lands. This could lead to a 
profitable and sustainable post-mining land use for communities while contributing to energy independence.

\section{Effects of Fertilizer on Switchgrass Growth}

The nutrient requirements of switchgrass vary with the management practices, yield potential of the site, and the productivity of the cultivar (Vogel et al., 2002). Although switchgrass can be grown on marginal soils with low soil fertility for the production of biofuels (McLaughlin and Kszos, 2005; Samson et al., 2005), fertilizer application can increase biomass production thus improving its economic profitability for biofuel production (Kering et al., 2013). Studies have shown positive relationships between nitrogen $(\mathrm{N})$ application and switchgrass biomass yields on marginal soils (Guretzky et al., 2011; Muir et al., 2001; Sanderson et al., 1999; Vogel et al., 2002;). Muir et al. (2001) tested the effects of $\mathrm{N}$ application on Alamo switchgrass in Texas and found that water and $\mathrm{N}$ are the principal resources limiting productivity of this cultivar. Phosphorus $(\mathrm{P})$ rate did not affect switchgrass growth in this study nor did it affect growth on marginal soils in a study done by Jung et al. (1988). Biomass production in the form of increased tiller mass increased with increasing $\mathrm{N}$ rate during the study done by Muir et al. (2001). Yields in this study peaked or began to level off when $\mathrm{N}$ application reached $168 \mathrm{~kg} \mathrm{ha}^{-1}$. In a study done by Kering et al., (2012) in soils with low plant available P that received P application (45 $\mathrm{kg} \mathrm{P} \mathrm{ha}^{-1}$ ), biomass yield increased up to $17 \%$, while $\mathrm{N}$ application increased biomass by more than $45 \%$ on average. In order to sustain soil productivity even on marginal soils with low initial nutrient productivity, long term nutrient management is necessary for increased biomass yield (Kering et al., 2012). In a study by Jung et al. (1988), monocultures of switchgrass were grown on acid soils with $\mathrm{pH}$ ranging from 4.3 to 4.9. $\mathrm{P}$ and $\mathrm{N}$ were applied to test yield responses to these nutrient treatments at a rate of 0,20 , or $40 \mathrm{~kg} \mathrm{P} \mathrm{ha}^{-1}$ 
(superphosphate) and 0,40 , or $80 \mathrm{~kg} \mathrm{~N} \mathrm{ha}^{-1}$ (ammonium nitrate). In this study, increased rates of $\mathrm{N}$ fertilizer significantly increased biomass yields but $\mathrm{P}$ fertilizer application did not (Jung et al., 1988). Warm season grasses generally will only respond to $P$ fertilization when $P$ is applied in combination with $\mathrm{N}$ and available soil $\mathrm{N}$ levels are often too low to produce responses to $\mathrm{P}$ fertilizer alone (Jung et al., 1988). In summary, the effects of fertilizer on switchgrass yield, specifically $\mathrm{N}$ fertilizers, show that in most cases $\mathrm{N}$ is a limiting factor in soils and application of $\mathrm{N}$ fertilizer will increase yield on marginal soils. Applications of $\mathrm{P}$ fertilizers have been shown to increase yields only when used in conjunction with $\mathrm{N}$ fertilizers. In order to provide soil sustainability for commercial harvesting, long-term nutrient management by fertilizer application is necessary for increased biomass yields.

\section{Nitrogen Use Efficiency (NUE) of Switchgrass}

The primary macronutrient that limits plant growth in most soils is $\mathrm{N}$ (Berendse and Aerts, 1987). All plants vary greatly in their ability to efficiently take up and use $\mathrm{N}$ (Berendse and Aertis, 1987; Chapin, 1980). Plants lose $\mathrm{N}$ to the soil in various different ways including root turn-over, leaf mortality, herbivory, leaching, seed production, root exudation, and from mechanical harvesting. Plants that have high N-use-efficiency in N-poor environments are still capable of producing biomass. The amount of $\mathrm{N}$ lost from a population during a given time is defined as the $\mathrm{N}$ requirement (Berendse and Aerts, 1987). When plants absorb more $\mathrm{N}$ than that which is required for growth, their biomass production increases. If they absorb less, then their biomass production declines (Berendse and Aerts, 1987).

Management of switchgrass for bioenergy production requires optimizing its $\mathrm{N}$-use efficiency with respect to production desires (Lemus et al., 2008). There are many descriptions for the definition of $\mathrm{N}$ use efficiency (NUE). The most commonly used description for NUE is 
the dry mass productivity per unit $\mathrm{N}$ taken up from the soil (Hirose, 2011). Two components that are useful when measuring the efficiency of $\mathrm{N}$ use are the mean residence time of $\mathrm{N}$ in the plant, and the rate of carbon fixation per unit of $\mathrm{N}$ in the plant (Berendse and Aerts, 1987). These components are critical to understanding where $\mathrm{N}$ allocation will occur within the plant for biomass production (Berendse and Aerts, 1987). In a study by Lemus et al. (2008), NUE measurements suggested that higher rates of $\mathrm{N}$ application caused diminishing returns of biomass. Based on their findings, Lemus et al. (2008) suggest that less than $90 \mathrm{~kg} \mathrm{~N} \mathrm{ha}^{-1} \mathrm{yr}^{-1}$ would provide good yields and also good N-use in switchgrass. Roughly $80 \%$ of applied N appeared to be recovered in biomass over a 3-year period at $90 \mathrm{~kg} \mathrm{~N} \mathrm{ha}{ }^{-1}$, while only 25 to $50 \%$ appeared to be recovered in a 3-year period with higher application rates (Lemus et al., 2008). Because of the ability of switchgrass to develop mobile $\mathrm{N}$ reserves through translocation prior to harvesting in late autumn, switchgrass has the potential to be highly productive under minimal $\mathrm{N}$ inputs (Lemus et al., 2008).

\section{Switchgrass Management on Mine Soils}

Surface mining is one of the most drastic disturbances that takes place on the landscape. It can permanently disrupt surface and subsurface hydrologic regimes, significantly disrupt soil development, remove vegetation, and alter topography. Reclamation of these disturbances is lawenforced and necessary to restore landscapes back to original contour and develop habitat and ecosystems. Reclamation practices generally include replacing overburden materials and spreading topsoil to about $30 \mathrm{~cm}$ depth. One of the concerns with reclaiming these soils is increased bulk density (BD) due to compaction from equipment spreading the top soil. High BD soils have low pore space resulting in poor aeration, restricted root zones, decreased water retention, and nutrient limitations (Seybold et al., 2004; Shrestha and Lal, 2011). Soil 
compaction is the most limiting factor in restoring native vegetation to these disturbed lands (Sinnett et al., 2008). Mechanical practices such as ripping and decreasing heavy machine traffic during reclamation and spreading topsoil will help decrease compaction. Also, choosing native species with high biomass production and deep, extensive rooting systems can help break up soil compaction and reduce BD. Switchgrass can be used as a reclamation tool that can help amend disturbed soils because of its high biomass production on these restrictive, nutrient-poor sites. However, like any plant, switchgrass also requires nutrients to establish growth, especially when existing nutrients are so limiting. $\mathrm{N}$ accumulation is very slow in new developing ecosystems. According to Marrs et al. (1983), total soil $\mathrm{N}$ should be 10 to 20 times the annual plant uptake during development on these poor sites. $\mathrm{N}$ fertilization is necessary to establish switchgrass yields on reclaimed mine sites. For any crop management, soil fertility is a major component. Proper N management can reduce costs associated with production of biomass (Anderson et al., 2013). Management practices that can increase yield response to $\mathrm{N}$ and reduce $\mathrm{N}$ requirements on marginal soils include implementing one-cut harvest systems and harvesting after a killing frost or after the growing season (Lee et al., 2007; Parrish and Fike, 2005). A study done on low fertility soils and low organic matter soils in Texas showed high biomass productivity with $\mathrm{N}$ application of up to $168 \mathrm{~kg} \mathrm{~N} \mathrm{ha}^{-1}$ (Muir et al., 2001). Other ways to manage switchgrass stands on marginal soils is to apply slow-release forms of $\mathrm{N}$ early in the season rather than applying $\mathrm{N}$ when it is immediately available in the spring (Anderson et al., 2013). However, this study showed that slow-release $\mathrm{N}$ fertilization is undesirable when the end use is bioenergy production due to the high $\mathrm{N}$ concentrations in biomass (Anderson et al., 2013). 


\section{Study Objectives}

The objective of this study was to collect and test the switchgrass biomass yields at Coal Mac and Black Castle sites after the $4^{\text {th }}$ and $5^{\text {th }}$ year of establishment to follow up research previously done at these sites (Brown et al., 2014). The goal was to measure the effects of different fertilizer rates by determining biomass yields on two reclaimed mine sites in southern WV. The hypothesis was that due to the trend seen in previous data, where biomass yields were highest from plots receiving the highest fertilizer treatment, the most recent collection will also find that the highest yields will be from the highest fertilizer treatment due to the initial increase in nutrients from fertilization during establishment in 2011.

\section{Materials and Methods}

\section{Site Locations}

Two reclaimed mine sites in WV were previously chosen in 2011 to evaluate the effects of different fertilizer and mulch treatments on yield potential of Cave-in-Rock switchgrass. The first site, Coal Mac, is located in Mingo, Logan, and Boone Counties $\left(37.7^{\circ} \mathrm{N} 82.0^{\circ} \mathrm{W}\right.$ ) (Figure 2.1). This site is a large mountain top surface mine operated by Coal-Mac, part of Arch Coal, Inc. Draglines, shovels, and loaders were used to remove overburden and coal from this site. Reclamation was done by applying a 60 - to $90-\mathrm{cm}$ depth of topsoil and weathered rock material over compacted gray sandstone overburden. A small agricultural offset disk harrow and tractor were used to prepare this site for planting. Planting, fertilizing, and mulching were done at the end of May in 2011 by previous students researching these effects.

The second site, Black Castle, is located in Boone County $\left(38.1^{\circ} \mathrm{N} 81.7^{\circ} \mathrm{W}\right)$ (Figure 2.1$)$. This site is a large mountaintop surface mine operated by Black Castle Mining Company, owned by Alpha Natural Resources. In 2011, reclamation was done by leveling the replaced 
unweathered overburden and covering it with a 20 - to $30-\mathrm{cm}$ depth of topsoil mixed with crushed weathered rock. Planting, fertilizing, and mulching occurred in the middle of June in 2011.

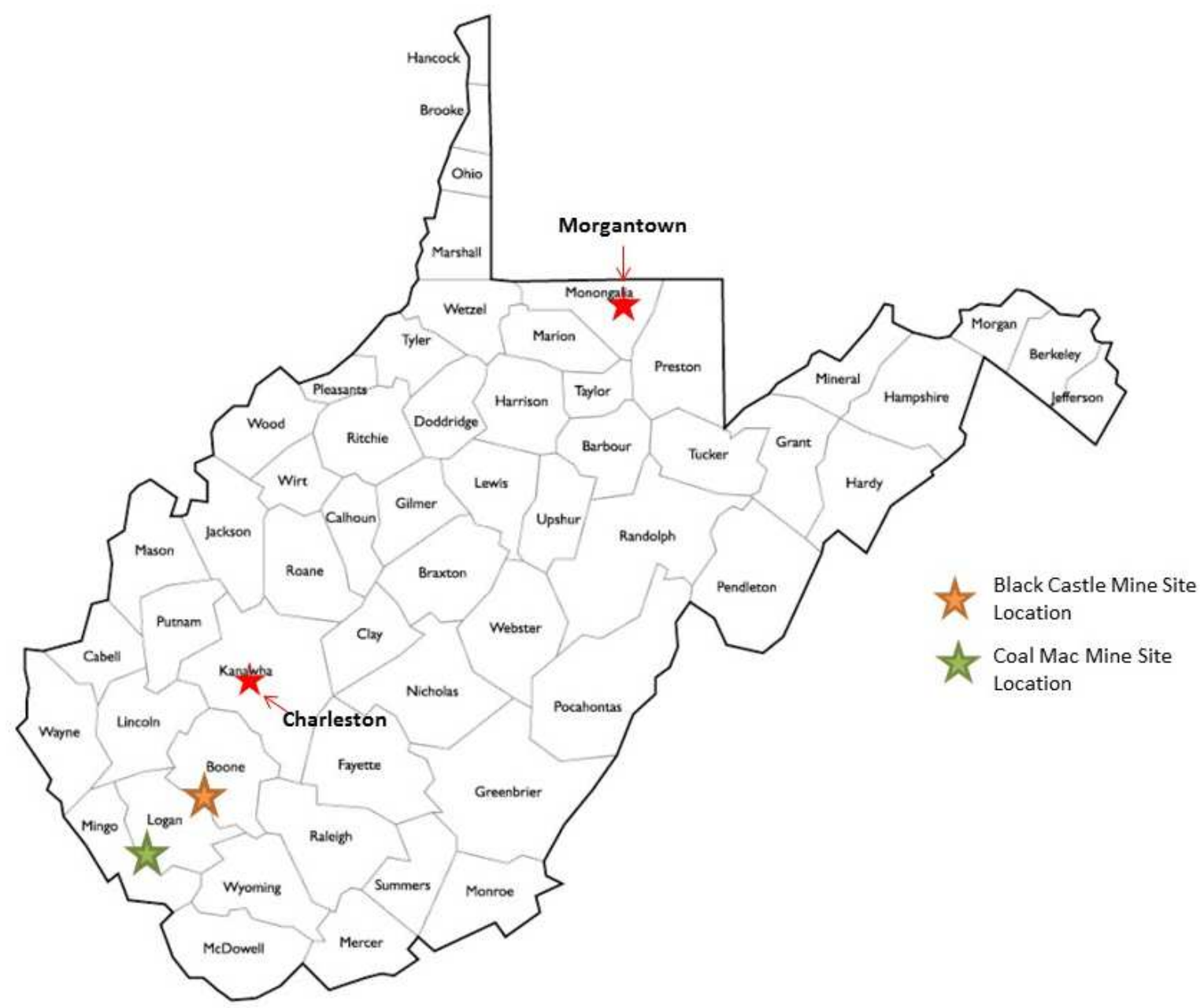

Figure 2.1: Map showing Black Castle and Coal Mac sites in WV..

\section{Treatment and Experimental Design}

At Coal Mac and Black Castle sites, four treatments were applied at planting in 2011 to determine the effects of three levels of mixed fertilizer and two levels of hydromulch. A randomized complete block design with five blocks was used. Treatments were assigned to plots in each of the five blocks. Fertilizer $\left(19-19-19, \mathrm{~N}-\mathrm{P}_{2} \mathrm{O}_{5}-\mathrm{K}_{2} \mathrm{O}\right)$ was applied evenly by hand to attain rates of 0,34 , or $68 \mathrm{~kg} \mathrm{ha}^{-1}$ of each nutrient in assigned plots. Wood cellulosic mulch was 
applied at $1.7 \mathrm{Mg} \mathrm{ha}^{-1}$ or $3.0 \mathrm{Mg} \mathrm{ha}^{-1}$ rates to test mulching effects at low and high rates respectively. The treatments were as follows:

- No fertilizer, light mulch: Control

- Low fertilizer, light mulch: $34 \mathrm{~kg} \mathrm{~N}-\mathrm{P}_{2} \mathrm{O}_{5}-\mathrm{K}_{2} \mathrm{O}_{\text {ha }}{ }^{-1}$ and $1.7 \mathrm{Mg}^{-1}$ hydromulch

- High fertilizer, light mulch: $68 \mathrm{~kg} \mathrm{~N}-\mathrm{P}_{2} \mathrm{O}_{5}-\mathrm{K}_{2} \mathrm{O} \mathrm{ha}^{-1}$ and $1.7 \mathrm{Mg} \mathrm{ha}^{-1}$ hydromulch

- Low fertilizer, heavy mulch: $34 \mathrm{~kg} \mathrm{~N}-\mathrm{P}_{2} \mathrm{O}_{5}-\mathrm{K}_{2} \mathrm{O} \mathrm{ha}^{-1}$ and $3.0 \mathrm{Mg} \mathrm{ha}^{-1}$ hydromulch

Certified Cave-in-Rock switchgrass seed was applied using a Solo 421-S portable

spreader at a rate of $11.2 \mathrm{~kg}$ pure live seed (PLS) ha- ${ }^{-1}$. Three randomly-selected sampling points were used to take biomass and soil samples from each plot (Figure 2.2 and 2.3).

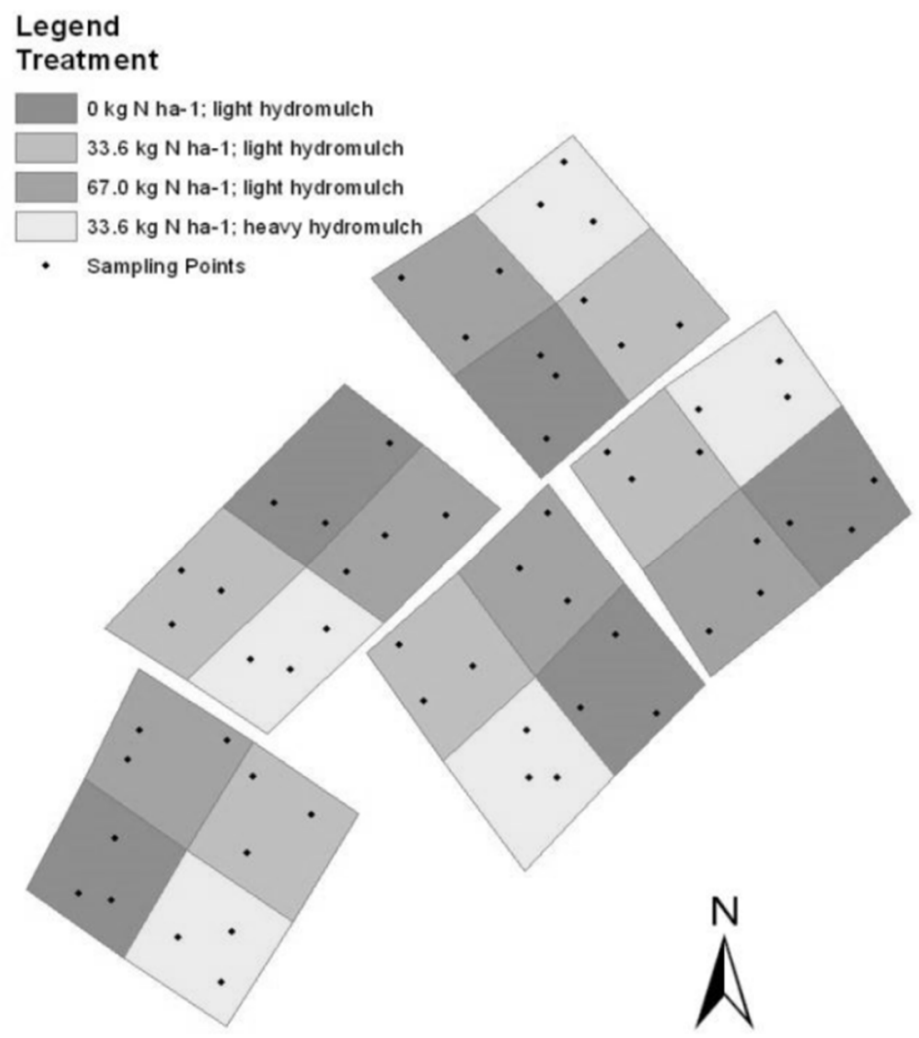

Figure 2.2: Map of research blocks, plots, and sampling points at Coal Mac. 


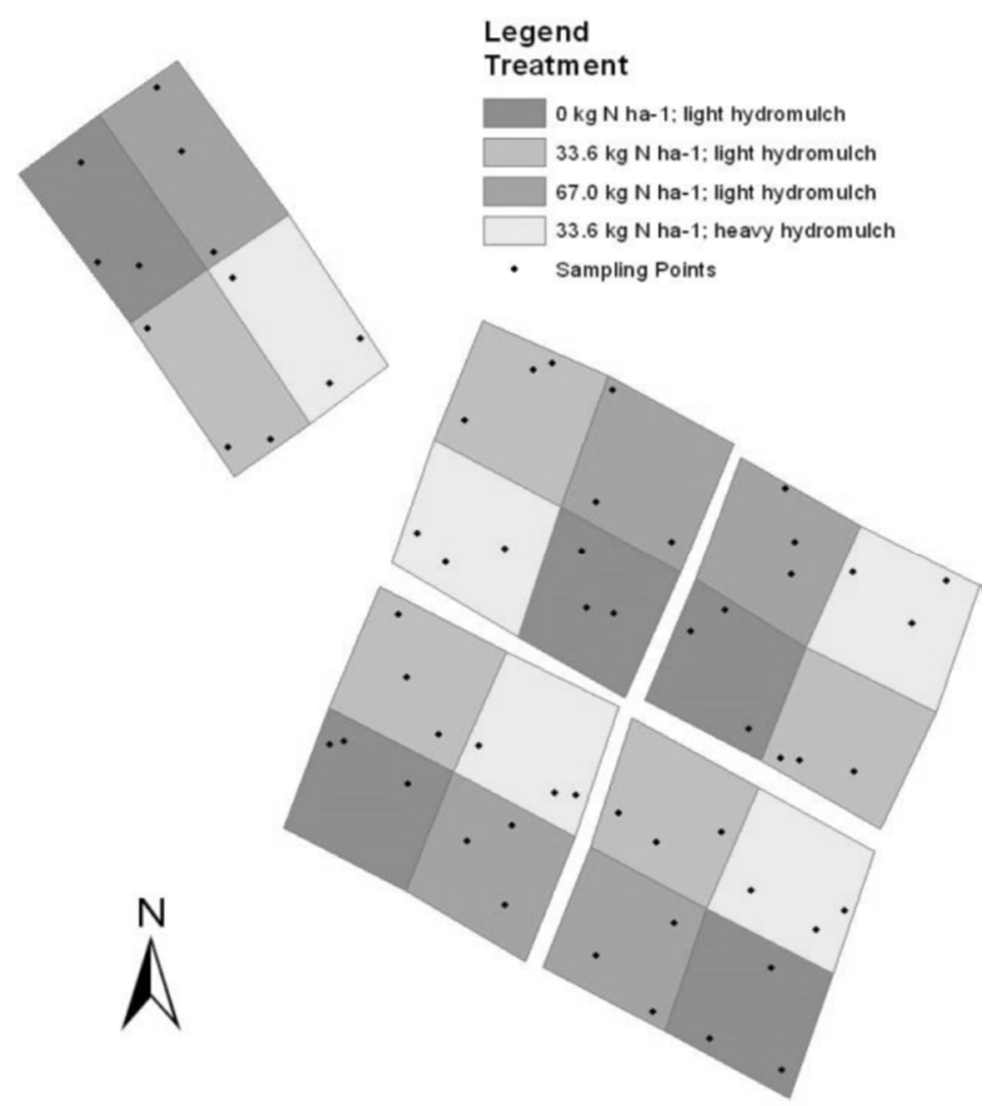

Figure 2.3: Map of research blocks, plots, and sampling points at Black Castle.

\section{Vegetation Sampling}

Three biomass samples from each plot were collected in $0.21-\mathrm{m}^{2}$ quadrats. All samples were taken at the post-anthesis stage of switchgrass growth in October of year 2014 and 2015. Biomass within the quadrat was clipped at a $10-\mathrm{cm}$ stubble height and biomass from any other plant species was removed from the sample. The samples were then oven dried at $60^{\circ} \mathrm{C}$ to a constant weight to determine dry weight.

\section{Soil Sampling}

Three soil samples were collected from each plot within each block in 2015. These were composited for a total of one sample in each block. Soil samples were collected by taking a 
shovel slice to approximately $15-\mathrm{cm}$ depth. Soil samples were then air-dried and sieved to obtain a soil sample composed of $\leq 2 \mathrm{~mm}$-sized material (fine fraction). The fine fraction was then used for chemical analysis and analyzed for percent fines, $\mathrm{pH}$, electrical conductivity (EC), $\mathrm{Al}, \mathrm{Ca}, \mathrm{Fe}$, $\mathrm{K}, \mathrm{Mn}, \mathrm{Mg}, \mathrm{P}, \mathrm{Ni}, \mathrm{Cu}$, and $\mathrm{Zn}$. To determine $\mathrm{pH}, 5 \mathrm{~g}$ of soil was combined with $5 \mathrm{~mL}$ of distilled de-ionized water, mixed for one hour, and then $\mathrm{pH}$ readings were taken using a $\mathrm{pH}$ Meter. EC readings were taken using a conductivity meter. Percent fines were determined from weights of whole soil and fractions. Subsamples of the fine fraction used for soil analysis were taken using a riffle splitter. Mehlich 1 solution was used to extract available elements from the soil using inductively coupled plasma mass spectrometry (ICP) analysis (Al, Fe, $\mathrm{Mn}, \mathrm{Mg}, \mathrm{Ca}, \mathrm{K}, \mathrm{P}, \mathrm{Ni}, \mathrm{Cu}$, and $\mathrm{Zn}$ ) (Wolf and Beegle, 1995).

\section{Statistical Analysis}

The experimental design to test the treatment effects at Coal Mac and Black Castle was a randomized split-plot design with five replications. Main plot represented the site, the subplot was the treatment. Data were log transformed to satisfy the assumptions of normal distributions for ANOVA, tested by Shapiro-Wilk normality test (Shapiro and Wilk, 1965). Data were analyzed by a split-plot ANOVA with repeated measures (Table 2.1) using PROC MIXED procedures of Statistical Analysis System (SAS) (SAS®, Version 9.3, SAS Institute Inc., Cary, NC, Copyright (C)2002-2010). Treatment (Control and 3 fertilized groups) and site (Coal Mac and Black Castle) were fixed factors with repeated effect of time (five years). Statistical significance was based on a P-value $\leq 0.05$ 
Table 2.1: Coal Mac and Black Castle split-plot ANOVA with repeated measures statistical design.

\begin{tabular}{lccc}
\hline Effect & $\begin{array}{c}\text { Mean Squares } \\
\text { (Abbreviation) }\end{array}$ & $\begin{array}{c}\text { Degrees of } \\
\text { Freedom }\end{array}$ & F-test \\
\hline Site & $\mathrm{MS}_{\mathrm{A}}$ & $\mathrm{a}-1=1$ & $\mathrm{MS}_{\mathrm{A}} /\left(\mathrm{MS}_{\mathrm{ABS}}+\mathrm{MS}_{\mathrm{AC}}-\mathrm{MS}_{\text {Residuas }}\right)$ \\
Treatment & $\mathrm{MS}_{\mathrm{B}}$ & $\mathrm{b}-1=3$ & $\mathrm{MS}_{\mathrm{B}} /\left(\mathrm{MS}_{\mathrm{ABS}}+\mathrm{MS}_{\mathrm{BC}}-\mathrm{MS}_{\text {Residual }}\right)$ \\
Interaction (Site)(Treatment) & $\mathrm{MS}_{\mathrm{AB}}$ & $(\mathrm{a}-1)(\mathrm{b}-1)=3$ & $\mathrm{MS}_{\mathrm{AB}} /\left(\mathrm{MS}_{\mathrm{ABS}}+\mathrm{MS}_{\mathrm{ABC}}-\mathrm{MS}_{\text {Resioual }}\right)$ \\
Main Plot Error & $\mathrm{MS}_{\mathrm{ABS}}$ & $\mathrm{ab}(\mathrm{s}-1)=32$ & \\
Year & $\mathrm{MS}_{\mathrm{C}}$ & $(\mathrm{c}-1)=3$ & $\mathrm{MS}_{\mathrm{C}} / \mathrm{MS}_{\text {Residual }}$ \\
Interaction (Site)(Year) & $\mathrm{MS}_{\mathrm{AC}}$ & $(\mathrm{a}-1)(\mathrm{c}-1)=6$ & $\mathrm{MS}_{\mathrm{AC}} / \mathrm{MS}_{\text {Residual }}$ \\
Interaction (Treatment)(Year) & $\mathrm{MS}_{\mathrm{BC}}$ & $(\mathrm{b}-1)(\mathrm{c}-1)=9$ & $\mathrm{MS}_{\mathrm{BC}} / \mathrm{MS}_{\text {Residual }}$ \\
Interaction (Site)(Treatment)(Year) & $\mathrm{MS}_{\mathrm{ABC}}$ & $(\mathrm{a}-1)(\mathrm{b}-1)(\mathrm{c}-1)=9$ & $\mathrm{MS}_{\mathrm{ABC}} / \mathrm{MS}_{\text {Residual }}$ \\
Residual Error & $\mathrm{MS}_{\text {Residual }}$ & $\mathrm{ab}(\mathrm{c}-1)(\mathrm{s}-1)=72$ & \\
\hline
\end{tabular}

\section{Results and Discussion}

Soil analysis for Black Castle and Coal Mac showed similar $\mathrm{pH}$ results with both sites averaging a slightly acidic $\mathrm{pH}$ of 6.0 and 6.6 respectively (Table 2.2 ). While this is slightly below a neutral $\mathrm{pH}$, switchgrass will thrive in soil $\mathrm{pH}$ 's that range from 5 to 8 (McLaughlin and Kszos, 2005). Both sites showed lower EC's than expected on a reclaimed mine site such as these. Averaged over each site for 2015, Black Castle had an EC of $81 \mu \mathrm{S} \mathrm{cm}^{-1}$ and Coal Mac averaged an EC of $42 \mu \mathrm{S} \mathrm{cm}^{-1}$ (Table 2.2). Percent fines were higher than expected on a reclaimed mine site. Most surface mines in this region have mine soils with percent fines in the 30 to 50\% range (Sinnett et al., 2008). Particle size distribution and textural class for each site was previously determined by Marra et al. (2013). Textural class for Black Castle was determined to be a loam and a sandy loam texture was determined for Coal Mac. Black Castle had an average percent sand of $51 \%, 35 \%$ silt, and $13 \%$ clay (Table 2.2 ). Coal Mac had an average of $60 \%$ sand, $28 \%$ silt, and $12 \%$ clay (Table 2.2 ). Coal Mac had higher levels of macroand micronutrients (Table 2.3). Levels of heavy metals such as copper and zinc were present at both sites and were higher at Coal Mac than Black Castle (Table 2.3). Nickel was also present at both sites equally $\left(0.2 \mathrm{mg} \mathrm{kg}^{-1}\right.$; Table 2.3$)$. 
Table 2.2. Chemical and physical soil characteristics averaged for each site for 2015.

\begin{tabular}{ccc}
\hline Parameter & Black Castle & Coal Mac \\
\hline $\mathrm{pH}$ & 6.0 & 6.6 \\
$\mathrm{EC}\left(\mu \mathrm{S} \mathrm{cm}^{-1}\right)$ & 81 & 42 \\
\% Fines & 70 & 69 \\
\% Sand & 51 & 60 \\
\% Clay & 13 & 12 \\
\% Silt & 35 & 28 \\
\hline
\end{tabular}

Table 2.3. Values of extractable soil nutrients using Mehlich 1 solution at Black Castle and Coal Mac for 2015.

\begin{tabular}{ccc}
\hline Parameter & Black Castle & Coal Mac \\
\hline & $-------\mathrm{mg} \mathrm{kg}^{-1}------$ \\
$\mathrm{Al}$ & 20.6 & 69.1 \\
$\mathrm{Fe}$ & 11.2 & 30.8 \\
$\mathrm{Mn}$ & 6.2 & 24.2 \\
$\mathrm{Mg}$ & 35.4 & 132.1 \\
$\mathrm{Ca}$ & 354 & 393.2 \\
$\mathrm{~K}$ & 9.8 & 80.7 \\
$\mathrm{P}$ & 3.9 & 290 \\
$\mathrm{Cu}$ & 0.4 & 580.4 \\
$\mathrm{Zn}$ & 0.5 & 414.9 \\
$\mathrm{Ni}$ & 0.2 & 0.2 \\
\hline
\end{tabular}

Averaged over two years, Back Castle and Coal Mac had similar yields (Table 2.4), which was expected since they were reclaimed similarly and had comparable soil chemical and physical properties (Table 2.2). There was a significant interaction between treatment and year (Table 2.4; Figure 2.4). In 2014, the treatment receiving 0 fertilizer $\left(2.7 \mathrm{Mg} \mathrm{ha}^{-1}\right)$ was significantly different from all other treatments in 2014 and different from the treatment receiving $67 \mathrm{~kg}_{\text {fertilizer ha }}{ }^{-1}\left(6.0 \mathrm{Mg} \mathrm{ha}^{-1}\right)$ in 2015 (Table 2.4). Black Castle and Coal Mac yielded 5.0 Mg ha ${ }^{-1}$ and 5.5 $\mathrm{Mg} \mathrm{ha}^{-1}$ respectively, averaged over 2014 and 2015 (p>0.05). Treatment effects on yield differed statistically as predicted; the yields in treatments receiving 0 
$\mathrm{kg}$ fertilizer ha ${ }^{-1}$ were significantly lower $\left(3.4 \mathrm{Mg} \mathrm{ha}^{-1}\right)$ than treatments receiving $33.6 \mathrm{~kg}$ fertilizer ha ${ }^{-1}$ with light mulch, $33.6 \mathrm{~kg}$ fertilizer ha ${ }^{-1}$ with heavy mulch, and $67 \mathrm{~kg}$ fertilizer ha ${ }^{-1}$ (Figure 2.4). The treatment with the highest yielding biomass $\left(6.5 \mathrm{Mg} \mathrm{ha}^{-1}\right)$ was the treatment receiving the highest fertilization, $67 \mathrm{~kg}$ fertilizer ha ${ }^{-1}$ (Table 2.4). Treatments receiving $33.6 \mathrm{~kg}$ fertilizer ha ${ }^{-1}$ and light mulch averaged $5.3 \mathrm{Mg} \mathrm{ha}^{-1}$ of biomass while treatments receiving the same amount of fertilizer and high mulch averaged higher yields at $5.8 \mathrm{Mg} \mathrm{ha}^{-1}$; however these yields were not statistically significant (Table 2.4). From these results, it is clear that fertilizer amendments increase biomass yields on reclaimed surface mines. The mulch effect on biomass yield was not so striking, but mulch is known to improve soil temperature, moisture, and water holding capacity (Cook et al., 2006).

There was no significant decline in biomass yield from 2014 to 2015 (Table 2.4). In 2015, the fifth year of establishment, both sites averaged $4.7 \mathrm{Mg} \mathrm{ha}^{-1}$, which was lower than the average yield in 2014 of $5.8 \mathrm{Mg} \mathrm{ha}^{-1}$ (Table 2.4). Fertilizer and mulch were not re-applied in 2015, so it is possible that yield declined due to no soil amendments that year (Table 2.4). 


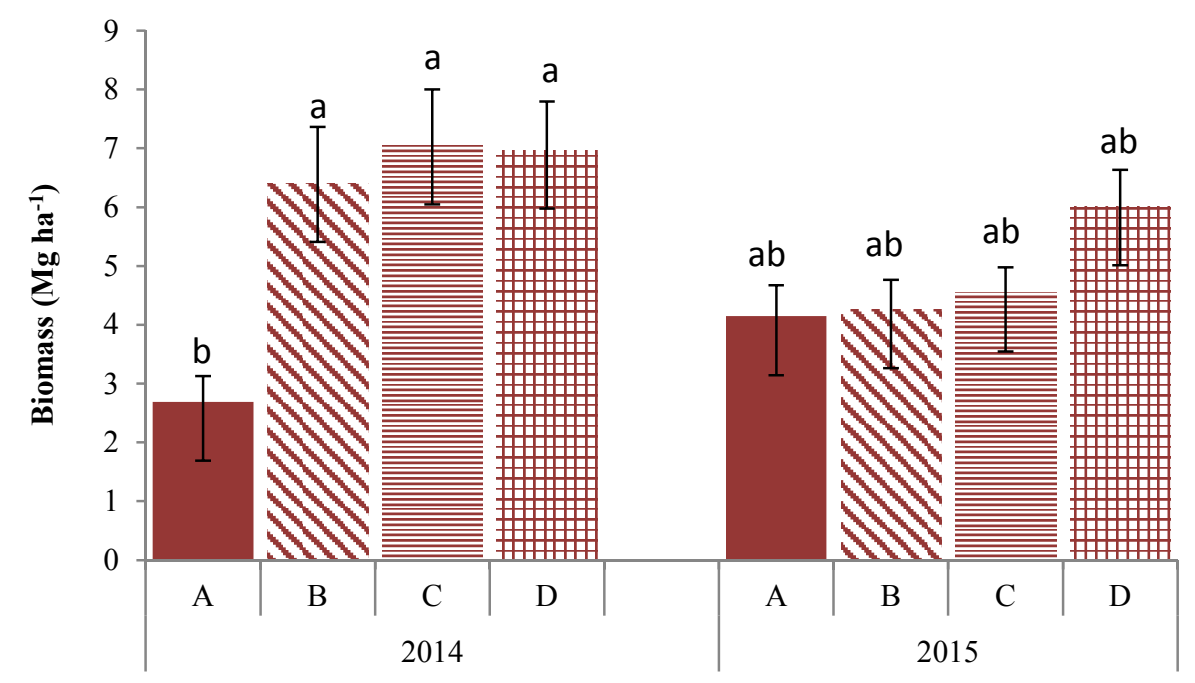

Figure 2.4: Displays treatment by year interaction between biomass $\left(\mathrm{Mg} \mathrm{ha}^{-1}\right)$ averaged over site per year. Asterisk shows treatments with significance $(*) . A=0$ Fertilizer ha ${ }^{-1} /$ Light Mulch; $B=33.6 \mathrm{~kg}$ Fertilizer ha $^{-1} /$ Light Mulch; $\mathrm{C}=33.6 \mathrm{~kg}$ Fertilizer ha ${ }^{-1} /$ Heavy Mulch; $\mathrm{D}=67 \mathrm{~kg}$ Fertilizer ha ${ }^{-1} /$ Light Mulch.

\section{Conclusion}

Fertilizer is an important amendment for vegetative growth on mine soils. N, particularly, is known to be the limiting factor in most soils. Because surface mining drastically disturbs soils, nutrients are even more limiting. Reclaimed soils must be fertilized in order to provide some medium for vegetative growth. This study was conducted to test the effects of a 19-19-19 fertilizer on nutrient-poor reclaimed mine sites in southern West Virginia. Switchgrass yielded 6.5 $\mathrm{Mg} \mathrm{ha}^{-1}$, the highest biomass yield on average over both sites when $67 \mathrm{~kg}_{\text {fertilizer has }}{ }^{-1}$ was applied. Overall, both sites were not significantly different in biomass yields, but this was expected due to the similar reclamation practices and soil properties we measured. Fertilizers can increase biomass yields on reclaimed surface mines, thereby increasing the ability to vegetate and restore reclaimed lands to desired productivity post-mining. 
Table 2.4. Black Castle and Coal Mac statistical significance biomass yields for main effect of site, treatment, year, and interaction between treatment and year.

\begin{tabular}{|c|c|c|c|c|}
\hline Effect & & & $\mathbf{P}>\mathbf{F}$ & Yield \pm SE \\
\hline & & & & $\mathrm{Mg} \mathrm{ha}^{-1}$ \\
\hline Site & & & 0.31 & \\
\hline & Black Castle & & & $5.0 \pm 1.0$ \\
\hline & Coal Mac & & & $5.5 \pm 0.9$ \\
\hline Treatı & & & $<0.01$ & \\
\hline & No fertilizer; light mulch & & & $3.4^{b} \pm 0.3$ \\
\hline & $33.6 \mathrm{~kg}$ fertilizer ha ${ }^{-1}$; light mulch & & & $5.3^{\mathrm{a}} \pm 0.5$ \\
\hline & $33.6 \mathrm{~kg}$ fertilizer ha ${ }^{-1}$; heavy mulch & & & $5.8^{\mathrm{a}} \pm 0.5$ \\
\hline & $67 \mathrm{~kg}$ fertilizer $\mathrm{ha}^{-1} ;$ light mulch & & & $6.5^{\mathrm{a} \pm 0.5}$ \\
\hline Year & & & 0.36 & \\
\hline & 2014 & & & $5.8 \pm 0.8$ \\
\hline & 2015 & & & $4.7 \pm 0.5$ \\
\hline Treatr & nt $x$ Year & & $<0.01$ & \\
\hline & No fertilizer; light mulch & 2014 & & $2.7^{\mathrm{b}} \pm 0.4$ \\
\hline & $33.6 \mathrm{~kg}$ fertilizer ha ${ }^{-1} ;$ light mulch & 2014 & & $6.4^{\mathrm{a}} \pm 1.0$ \\
\hline & $33.6 \mathrm{~kg}$ fertilizer ha ${ }^{-1}$; heavy mulch & 2014 & & $7.0^{\mathrm{a}} \pm 1.0$ \\
\hline & $67 \mathrm{~kg}$ fertilizer ha ${ }^{-1} ;$ light mulch & 2014 & & $7.0^{\mathrm{a}} \pm 0.8$ \\
\hline & No fertilizer; light mulch & 2015 & & $4.1^{\mathrm{ab}_{ \pm 0}}{ }_{0.5}$ \\
\hline & $33.6 \mathrm{~kg}$ fertilizer ha ${ }^{-1} ;$ light mulch & 2015 & & $4.3^{\mathrm{ab}} \pm 0.5$ \\
\hline & $33.6 \mathrm{~kg}$ fertilizer ha $\mathrm{h}^{-1}$; heavy mulch & 2015 & & $4.5^{\mathrm{ab}} \pm 0.4$ \\
\hline & $67 \mathrm{~kg}$ fertilizer ha ${ }^{-1}$; light mulch & 2015 & & $6.0^{\mathrm{a}} \pm 0.6$ \\
\hline
\end{tabular}

*Different letters denote significant difference within effects at $\mathrm{p}>0.05$ level of probability according to Tukey's HSD. Untransformed means are reported.

\section{Literature Cited}

Anderson, E.K., A.S. Parrish, T.B. Voigt, V.N. Owens, C.H. Hong, and D.K. Lee. 2013.

Nitrogen fertility and harvest management of switchgrass for sustainable bioenergy feedstock production in Illinois. Ind. Crop Prod. 48: 19-27. 
Berendse, F. and R. Aerts. 1987. Nitrogen-use-efficiency: A biologically meaningful definition. Funct. Ecol. 1: 293-296.

Brown, C. 2014. Biomass production, composition, and ethanol potential of switchgrass grown on reclaimed surface mines in West Virginia. M.S. thes., West Virginia Univ., West Virginia.

Chapin, F.S., III. 1980. The mineral nutrition of wild plants. Annu Rev Ecol Syst 11: 233-260.

Cook, H.F., G.S.B. Valdes, and H.C. Lee. 2006. Mulch effects on rainfall interception, soil physical characteristics and temperature under Zea mays L. Soil Till. Res. 91: 227-235.

Garten, C.T. Jr. and S.D. Wullschleger. 2000. Soil carbon dynamics beneath switchgrass as indicated by stable isotope analysis. J. Environ. Qual. 29: 645-653.

Guretzky J.A., J.T. Biermacher, B.J. Cook, M.K. Kering, and J. Mosali. 2011. Switchgrass for forage and bioenergy: harvest and nitrogen rate effects on biomass yields and nutrient composition. Plant Soil 339: 69-81

Hopkins, H. 1951. Ecology of the native vegetation of the loess hills in central Nebraska. Ecol. Monogr. 21: 125-147.

Jung, G.A., J.A. Shaffer, and W.L. Stout. 1988. Switchgrass and big bluestem responses to amendments on strongly acid soil. Agron. J. 80: 669-676.

Kering, M.K., J.T. Biermacher, T.J. Butler, J. Mosali, and J.A. Guretsky. 2012. Biomass yield and nutrient responses of switchgrass to phosphorus application. Bioenerg. Res. 5: 71-78.

Kering, M.K., T.J. Butler, J.T. Biermacher, J. Mosali, and J.A. Guretzky. 2013. Effect of potassium and nitrogen fertilizer on switchgrass productivity and nutrient removal rates under two harvest systems on a low potassium soil. Bioenerg. Res. 6: 329-335. 
Lee, D.K., J.J. Doolittle, and V.N. Owens. 2007. Soil carbon dioxide fluxes in establishment switchgrass land managed for biomass production. Soil Boil. Biochem. 39: 178-186.

Lemus, R., D.J. Parrish, and O. Abaye. 2008. Nitrogen-use dynamics in switchgrass grown for biomass. Bioenerg. Res. 1: 153-162.

Liebig, M.A., M.R. Schmer, K.P. Vogel, and R.B. Mitchell. 2008. Soil carbon storage by switchgrass grown for bioenergy. Bioenerg. Res. 1: 215-222.

Marrs, R.H., R.D. Roberts, R.A. Skeffington, and A.D. Bradshaw. 1983. Nitrogen and the development of ecosystems. pp. 123-135. In: J.A. Lee et al. (Eds.) Nitrogen as an Ecological Factor. Blackwell Sci. Publ., Oxford.

McLaughlin, S.B. and L.A. Kszos. 2005. Development of switchgrass (Panicum virgatum) as a bioenergy feedstock in the United States. Biomass Bioenerg. 28: 515-535.

Muir J.P., M.A. Sanderson, W.R. Ocumpaugh, R.M. Jones, and R.L. Reed. 2001. Biomass production of Alamo switchgrass in response to nitrogen, phosphorus, and row spacing. Agron. J. 93:896-901.

Parrish, D.J. and J.H. Fike. 2005. The biology and agronomy of switchgrass for biofuels. Crit. Rev. Plant Sci. 24: 423-459.

Samson R., M. Sudhagar, R. Boddey, S. Sokhansanj, D. Quesada, S. Urquiaga, V. Reis, and C. H. Lem. 2005. The potential of C4 perennial grasses for developing a global bioheat industry. Crit. Rev. Plant Sci. 24:461-495

Sanderson, M.A., J.C. Read, and R.L. Reed. 1999. Harvest management of switchgrass for biomass feedstock and forage production. Agron. J. 91:5-10 
Schmer, M.R., K.P. Vogel, R.B. Mitchell and R.K. Perrin. 2008. Net energy of cellulosic ethanol from switchgrass. Proc. National Acad. Sci. 105: 464-469.

Seybold, C.A., R.B. Grossman, H.R. Sinclair, K.M. Williams, G.R. Struben, and S.L. Wade. 2004. Evaluating soil quality on reclaimed coal mine soils in Indiana. pp. 1644-1663. In: Proc. 2004 National Meeting of the American Society of Mining and Reclamation and The $25^{\text {th }}$ West Virginia Surface Mine Drainage Task Force, April 18-24, 2004. American Society of Mining and Reclamation, Lexington, KY,

Shapiro, S. S. and M.B. Wilk. 1965. An analysis of variance test for normality (complete samples). Biometrika. 52: 591-611.

Sinnett, D., J. Poole, and T.R. Hutchings. 2008. A comparison of cultivation techniques for successful tree establishment on compacted soil. Forestry 81: 663-679.

Shrestha, R. and R. Lal. 2009. Offsetting carbon dioxide emissions through minesoil reclamation. Climate adaption mitigation e-learning (CAMEL). Retrieved from http://www.eoearth.org/view/article/154999. Accessed January, 2016.

Shrestha, R. and R. Lal. 2011. Changes in physical and chemical properties of soil after surface mining and reclamation. Geoderma 161: 168-176.

Smith, D. 1975. Trends of nonstructural carbohydrates in the stem bases of switchgrass. J. Range Manage. 28: 389-391.

Statistical Analysis System. 2011. SAS/STAT systems for windows v.9.3. SAS Institute, Cary, N.C.

Vogel, K.P., J.J. Brejda, D.T. Walters, and D.R. Buxton. 2002. Switchgrass biomass production in the Midwest USA: Harvest and Nitrogen Management. Agron. J. 94: 413-420. 
Vogel, K.P. 2004. Switchgrass. In: Moser, L.E., B.L. Burson, and L.E. Sollenberger (Eds.). Warm-season (C4) grasses. American Society of Agronomy, Monograph 45: 561-588.

Waller, S.S., and J.K. Lewis. 1979. Occurrence of C3 and C4 photosynthetic pathways of North American grasses. J. Range Manage. 32: 12-28.

Weaver, J.E. and R. W. Darland. 1949. Soil-root relationships of certain native grasses in various soil types. Ecol. Monogr. 19: 303-338.

Wolf, A. and Beegle, D. 1995. Recommended soil tests for macronutrients: Phosphorus, Potassium, Calcium and Magnesium. p. 30-38. In: Sims, J.T. and A.M. Wolf (Eds.). Recommended Soil Testing Procedures for the Northeastern United States. Northeastern Regional Pub. No. 493 (2nd Ed). Agricultural Experiment Station Univ. of Delaware, Newark, DE.

Yang, J., E. Worley, M. Wang, B. Lahner, D.E. Salt, M. Saha, and M. Udvardi. 2009. Natural variation for nutrient use and remobilization efficiencies in switchgrass. Bioenerg. Res. 2: 257-266. 


\section{CHAPTER 3: YIELDS OF THREE SWITCHGRASS CULTIVARS GROWN ON RECLAIMED MINE SITES IN WEST VIRGINIA}

\section{Introduction to Lowland and Upland Switchgrass Cultivars}

Switchgrass has evolved to tolerate a wide range of climatic and edaphic conditions all over the United States. Studies have shown switchgrass yields ranging from 7 to $18 \mathrm{Mg}$ dry matter (DM) ha-1 in cold weather habitats with little input (Christian and Elbersen, 1988). This adaptation is partly due to the evolution of two distinct ecotypes - upland and lowland. Ecotypes can be recognized based on morphological characteristics and preferred climate and habitat (Monti et al., 2001). Lowland ecotypes tend to grow best in wetter soils, grow faster than upland ecotypes, and have a bunch-type growth habit (Hopkins et al., 1996; Monti et al., 2001). Upland ecotypes tend to grow in drier climates and possess decumbent growth habits (Hopkins et al., 1996; Monti et al., 2001). Upland ecotypes normally produce lower biomass yields than lowland ecotypes (Christian and Elbersen, 1988; Monti et al., 2001). Morphological differences between ecotypes include larger leaves and thicker stems for lowland ecotypes and thinner stems and larger seeds in upland ecotypes (Monti et al., 2001; Stroup et al., 2003). Monti et al. (2001), analyzed lowland and upland switchgrass varieties to assess which ecotype produced greater seed germination and emergence on marginal soils with different tillage techniques in Italy. The upland variety was Cave-in-Rock and lowland varieties were Alamo and Kanlow. There was no significant difference among ecotypes except in a no-till trial where the upland ecotype showed a higher emergence rate than lowland ecotypes (Monti et al., 2001). Porter (1966) revealed that lowland species had a lower $\mathrm{N}$ requirement than upland species under the same conditions. In a study done by Stroup et al. (2003), lowland varieties Alamo and Kanlow yielded significantly higher biomass than upland varieties Blackwell and Caddo under the same $\mathrm{N}$ fertilization (100 $\mathrm{kg} \mathrm{N} \mathrm{ha}{ }^{-1}$ ). Lowland species have greater growth potential than upland species, based on their 
ability to adjust to adverse environmental conditions such as low soil $\mathrm{N}$ and droughts (Stroup et al., 2003).

\section{Switchgrass Ecotype Variation for Biomass Production}

For over 15 years, bioenergy crops such as switchgrass have been studied for alternatives to current energy practices (McLaughlin and Kszos, 2005). In order to produce energy from herbaceous species that will be economically feasible, specific cultivars must be selected that produce higher biomass yields. Determining which cultivars will produce high yields requires knowledge of genetic variation and adaptations of different cultivars to certain growing conditions. Varieties that are ideal for bioenergy production should be adapted to management strategies that are in line with existing farming practices and have positive environmental impacts (McLaughlin and Kszos, 2005). Appropriate cultivar selection can have a huge impact on the productivity, persistence, and profitability of a crop (Lemus et al., 2002). In studies done over multiple states comparing cultivars for biomass production, the cultivars that consistently produced the highest biomass yields consistently were Alamo, Kanlow, and Cave-in-Rock (23.0, 18.2, and 16.3 $\mathrm{Mg} \mathrm{ha}^{-1}$, respectively) (McLaughlin and Kszos, 2005). In another study done by Lemus et al. (2002) in Iowa, 20 cultivars were selected to observe which cultivars produced the highest biomass yield and lowland ecotypes Kanlow and Alamo (13.1 and 12.1 $\mathrm{Mg} \mathrm{ha}^{-1}$, respectively) produced the most biomass (Lemus et al., 2002). Upland cultivars Cave-in-Rock and Shawnee produced significantly less biomass yields at 9.3 and $8.8 \mathrm{Mg} \mathrm{ha}^{-1}$, respectively (Lemus et al., 2002). One of the most important factors to consider when determining selection for maximum biomass production is cultivar adaptability and long-term winter hardiness to assure stand survival of any cultivar regardless of ecotype (Lemus et al., 2002). Although lowland ectypes have been shown to produce higher biomass yields, these studies have been 
conducted in areas where lowland ecotypes are generally more adapted (Lemus et al., 2002; McLaughlin and Kzsos, 2005).

\section{Cultivar Selection for Mine Land Reclamation}

The main objective in mine land reclamation is to establish permanent vegetative cover and to select appropriate species and cultivars to increase the opportunity for high establishment rates (Sutton and Dick, 1987). Switchgrass has already been studied for revegetation on mine soils and has been found to have successful establishment and also help decrease soil compaction and eliminate erosion hazards (Marra and Skousen, 2012; Marra et al., 2013; Sutton and Dick, 1987). Each cultivar possesses unique growth characteristics that determine its value in stabilizing soil, producing increased biomass for organic matter accumulation, and increasing carbon sequestration in these disturbed lands. Wullschleger et al. (2010) compared upland and lowland cultivars on marginal lands. Annual biomass yields for upland cultivars ranged from 5.2 to $11.1 \mathrm{Mg} \mathrm{ha}^{-1}$, with a site-wide average of $7.2 \mathrm{Mg} \mathrm{ha}^{-1}$. Overall, this study found that there was no significant difference in biomass of upland or lowland cultivars grown on marginal lands (Wullschleger et al., 2010). Evanylo et al. (2005) tested different species of grasses for reclamation and revegetation on mine soils in Virginia. Their study did not identify specific cultivars but reported that out of 11 different species, switchgrass was the highest yielding and adaptive species for reclamation (Evanylo et al., 2005).

Switchgrass is known for its extensive rooting systems that can reach depths of up to $4 \mathrm{~m}$ (Weaver and Darland, 1949). Variations in root morphologies among switchgrass cultivars can impact soil compaction, carbon stabilization, and soil carbon inputs (Adkins et al., 2016). Specific root lengths (SRL; $\mathrm{m} \mathrm{g}^{-1}$ root mass) can vary by a factor of five among cultivars (Adkins et al., 2016). SRL was measured for six different cultivars of switchgrass and Forestburg had the 
largest SRL by Adkins et al. (2016). Root length and rooting depth are important in mine land reclamation; the deeper the root penetrates the soil the greater the accessibility to nutrients and water. Longer roots are able to penetrate deeper into this soil. Larger rooting depths also help to decrease soil compaction.

\section{Study Objectives}

The objective for this study was to determine biomass yields of three cultivars of switchgrass (Cave-in-Rock, Shawnee, and Carthage) on two reclaimed mine sites that had different reclamation procedures. Both sites had been previously studied to test cultivar yields on reclaimed mine sites (Marra et al., 2013; Brown et al., 2014). Switchgrass seed was planted in 2008 at both sites and yields have been determine annually since 2009 at the end of each growing season. The goal was to test if Cave-in-Rock switchgrass still produced the highest yields after the $9^{\text {th }}$ year of growth as observed in previous years at both sites.

\section{Materials and Methods}

\section{Site Locations}

Two sites were chosen for this study. Establishment of both sites, Hampshire and Hobet, took place in 2008. The first site, Hampshire, is located on a small contour mine in Mineral County, WV $\left(39.4^{\circ} \mathrm{N}, 79.1^{\circ} \mathrm{W}\right)$ (Figure 3.1). Coal operations at Hampshire stopped in April, 1998 and the site is currently managed by the Upper Potomac River Commission. Smaller mining equipment and trucks were used during operations. Reclamation was completed by spreading topsoil and by periodic application of lime-treated sludge from the Westernport, MD municipal wastewater treatment plant. This plant treats industrial waste from the New Page paper mill and sewage from the town of Westernport. Sludge was applied in 1998 during reclamation 
and again in 2003 and 2008 at a rate of $225 \mathrm{Mg} \mathrm{ha}^{-1}$ (dry). A small bulldozer and offset disk harrow were used to prepare this site for planting.

The second site, Hobet, is a large mountaintop surface mine in Boone and Kanawha counties, WV $\left(38.1^{\circ} \mathrm{N}, 82.0^{\circ} \mathrm{W}\right)$ (Figure 3.1). Hobet is operated by Hobet Mining Company, a subsidiary of Patriot Coal. This mine consists of roughly 4,800 ha of operating and reclaimed mine lands. A large dragline was used for overburden removal. Reclamation was completed by placing a 1-m thick layer of crushed, unweathered rock material over compacted overburden and then tracked in by a bulldozer and allowed to sit without vegetation before establishing plots. A large earthmoving offset disk harrow was pulled across the site with a large bulldozer to till the soil before planting.

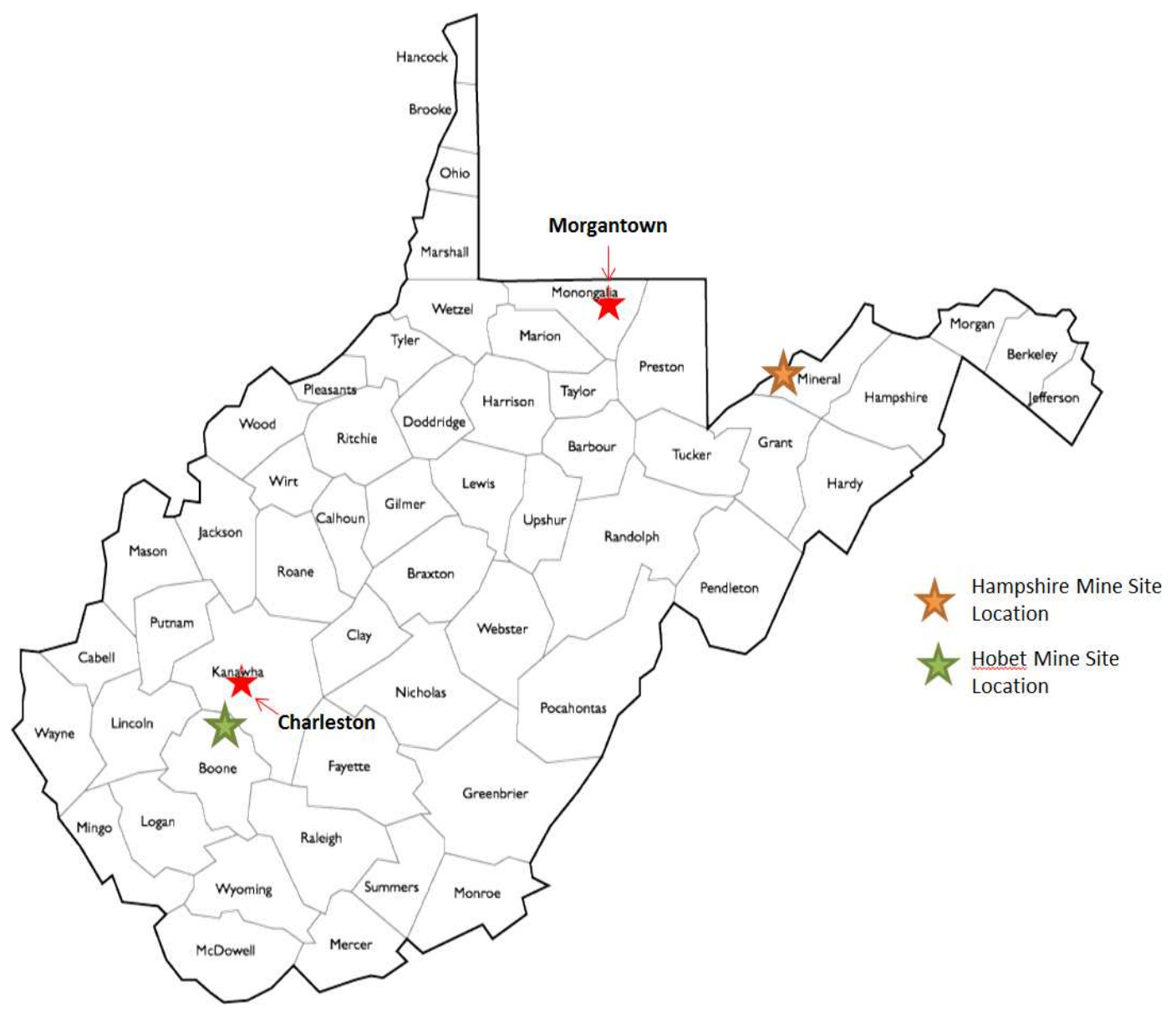


Figure 3.1: Schematic map showing Hampshire and Hobet sites.

\section{Treatment and Experimental Designs}

In 2008, a completely randomized design was used at each site with nine 0.4 -ha plots randomly assigned to one of three cultivars with three replications. Certified switchgrass seed for cultivars Cave-in-Rock, Carthage, and Shawnee, was purchased from Ernst Conservation Seeds (Meadville, PA) and the seed was broadcasted at each site at a rate of $11.2 \mathrm{~kg}$ pure live seed (PLS) ha ${ }^{-1}$ (Figure 3.2 and 3.3).

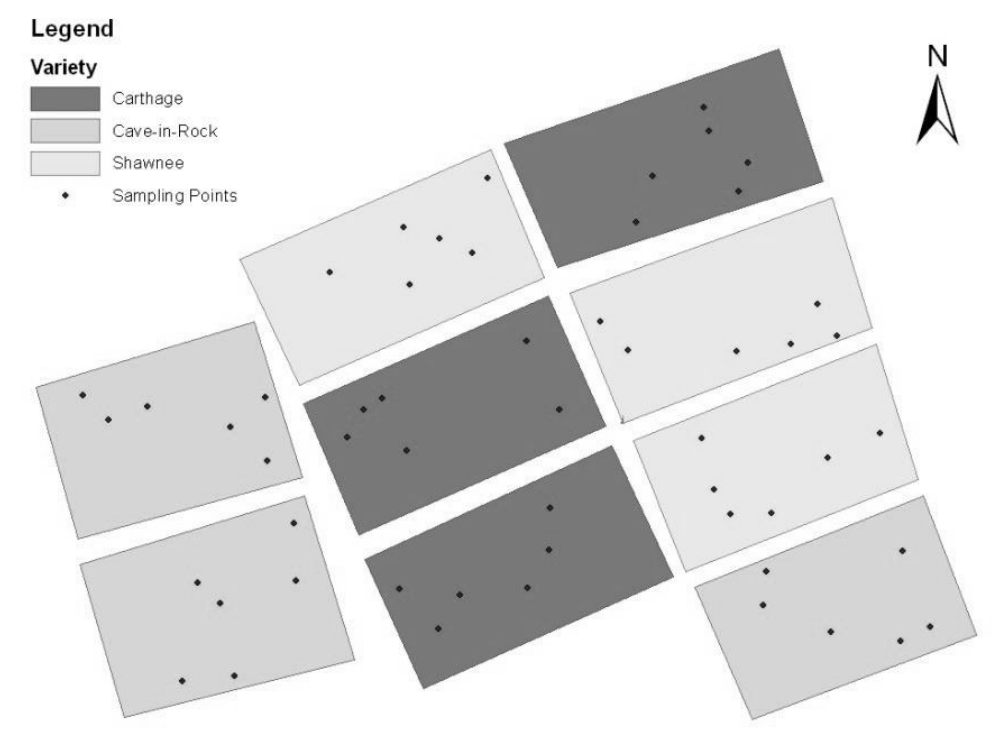

Figure 3.2: Map of Hampshire displaying example sample points and plot layout. 


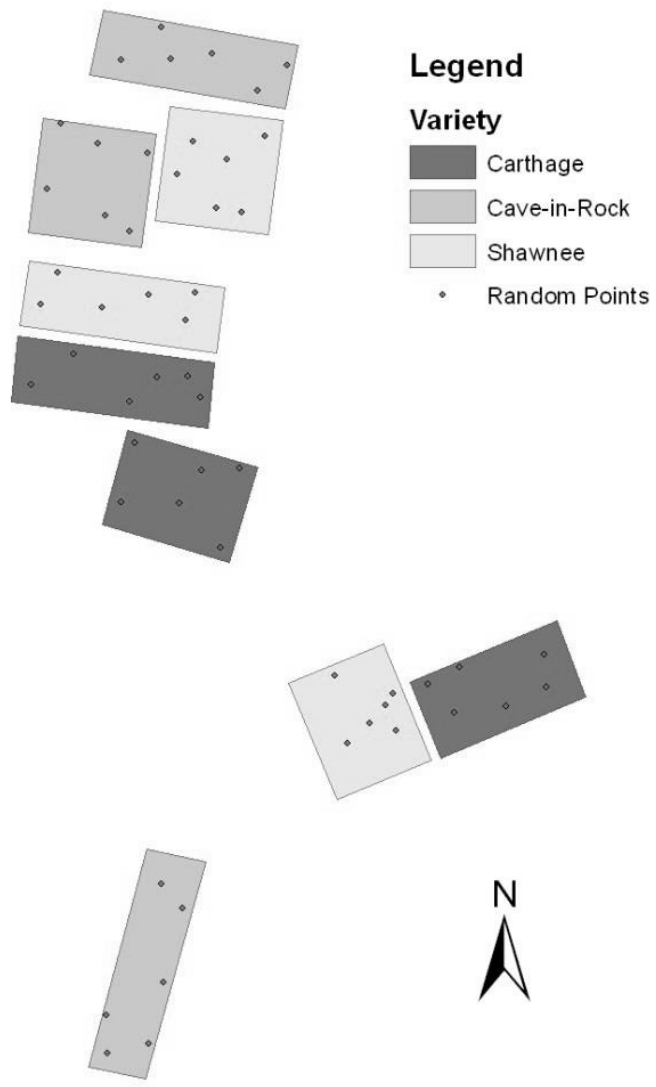

Figure 3.3: Map of Hobet displaying example sample points and plot layout.

\section{Vegetation Sampling}

Biomass has been sampled annually since 2009 at the end of each growing season during post-anthesis stage in October. Six sampling points were randomly chosen within each plot for aboveground biomass measurements and composited by clipping at approximately $10 \mathrm{~cm}$ above ground level in 0.21- $\mathrm{m}^{2}$ quadrats (Ashworth et al., 2014; Mitchell et al., 2008). Only switchgrass within the quadrat was sampled. The samples were then oven dried at $60^{\circ} \mathrm{C}$ to a constant weight to determine dry weight.

\section{Soil Sampling}

Three soil samples were collected from each plot at the same time clippings were taken. Samples were collected by taking a shovel slice to approximately $15-\mathrm{cm}$ depth and analyzed for 
percent fines, $\mathrm{pH}, \mathrm{EC}, \mathrm{Al}, \mathrm{Fe}, \mathrm{Mn}, \mathrm{Mg}, \mathrm{Ca}, \mathrm{K}, \mathrm{P}, \mathrm{Ni}, \mathrm{Cu}$, and $\mathrm{Zn}$. Soil samples were then airdried and sieved to obtain a soil sample composed of $\leq 2 \mathrm{~mm}$-sized material (fine fraction). The fine fraction was then used for chemical analysis. To determine $\mathrm{pH}, 5 \mathrm{~g}$ of soil was combined with $5 \mathrm{~mL}$ of distilled de-ionized water, mixed for 15 minutes, equilibrated for one hour, and then $\mathrm{pH}$ readings were taken using a $\mathrm{pH}$ Meter. EC readings were taken using a conductivity meter. Percent fines were determined from weights of whole soil and fractions. Subsamples of the fine fraction used for soil analysis were taken using a riffle splitter. Mehlich 1 solution was used to extract available elements from the soil using inductively coupled plasma mass spectrometry (ICP) analysis (Al, Fe, $\mathrm{Mn}, \mathrm{Mg}, \mathrm{Ca}, \mathrm{K}, \mathrm{P}, \mathrm{Ni}, \mathrm{Cu}$, and $\mathrm{Zn}$ ) (Wolf and Beegle, 1995).

\section{Statistical Analysis}

Biomass data for both locations were analyzed with sites being fixed effects and year (9 years) as a random effect. Mean values of biomass for each plot were used and normally distributed, verified by Shapiro-Wilk normality test (Shapiro and Wilk, 1965). Repeated measures ANOVA in PROC MIXED procedure of the Statistical Analysis System (SAS Institute Inc., Cary, NC, Copyright (C2013; SAS ${ }^{\circledR}$, Version 9.3, SAS Institute Inc., Cary, NC, Copyright (C)2002-2010) was utilized. Statistical significance was based on a $p$-value of $\leq 0.05$. 
Table 3.1: Hampshire and Hobet ANOVA with repeated measures statistical design.

\begin{tabular}{lccc}
\hline Effect & $\begin{array}{c}\text { Mean Squares } \\
\text { (Abbreviation) }\end{array}$ & Degrees of Freedom & F-test \\
\hline Site & $\mathrm{MS}_{\mathrm{A}}$ & $\mathrm{a}-1=1$ & $\mathrm{MS}_{\mathrm{A}} /\left(\mathrm{MS}_{\mathrm{ABS}}+\mathrm{MS}_{\mathrm{AC}}-\mathrm{MS}_{\mathrm{Residual}}\right)$ \\
Cultivar & $\mathrm{MS}_{\mathrm{B}}$ & $\mathrm{b}-1=2$ & $\mathrm{MS}_{\mathrm{B}} /\left(\mathrm{MS}_{\mathrm{ABS}}+\mathrm{MS}_{\mathrm{BC}}-\mathrm{MS}_{\mathrm{Residual}}\right)$ \\
Interaction (Site)(Cultivar) & $\mathrm{MS}_{\mathrm{AB}}$ & $(\mathrm{a}-1)(\mathrm{b}-1)=2$ & $\mathrm{MS}_{\mathrm{AB}} /\left(\mathrm{MS}_{\mathrm{ABS}}+\mathrm{MS}_{\mathrm{ABC}}-\mathrm{MS}_{\mathrm{Residual}}\right)$ \\
Main Plot Error & $\mathrm{MS}_{\mathrm{ABS}}$ & $\mathrm{ab}(\mathrm{s}-1)=12$ & $\mathrm{MS}_{\mathrm{C}} / \mathrm{MS}_{\text {Residual }}$ \\
Year & $\mathrm{MS}_{\mathrm{C}}$ & $(\mathrm{c}-1)=6$ & $\mathrm{MS}_{\mathrm{AC}} / \mathrm{MS}_{\text {Residual }}$ \\
Interaction (Site)(Year) & $\mathrm{MS}_{\mathrm{AC}}$ & $(\mathrm{a}-1)(\mathrm{c}-1)=6$ & $\mathrm{MS}_{\mathrm{BC}} / \mathrm{MS}_{\text {Residual }}$ \\
Interaction (Cultivar)(Year) & $\mathrm{MS}_{\mathrm{BC}}$ & $(\mathrm{b}-1)(\mathrm{c}-1)=12$ & $\mathrm{MS}_{\mathrm{ABC}} / \mathrm{MS}_{\text {Residual }}$ \\
Interaction (Site)(Cultivar)(Year) & $\mathrm{MS}_{\mathrm{ABC}}$ & $(\mathrm{a}-1)(\mathrm{b}-1)(\mathrm{c}-1)=12$ & \\
Residual Error & $\mathrm{MS}_{\text {Residual }}$ & $\mathrm{ab}(\mathrm{c}-1)(\mathrm{s}-1)=72$ & \\
\hline
\end{tabular}

\section{Results and Discussion}

Soil analysis for Hampshire and Hobet showed similar $\mathrm{pH}$ results (Table 3.2). Soil $\mathrm{pH}$ at both sites was slightly above neutral (7.4 and 7.6, respectively). Studies have shown that switchgrass will thrive in pH's that range from 5 to 8 (McLaughlin and Kszos, 2005). Hampshire had a significantly higher EC value than Hobet at $146 \mu \mathrm{S} \mathrm{cm}^{-1}$, which is due to Hampshire receiving sewage and paper mill sludge as a soil amendment thereby increasing the amount of salts present in the soil. Hobet had a low EC average value of $53 \mu \mathrm{S} \mathrm{cm}^{-1}$. Percent fines were higher than expected on these reclaimed mine sites compared to most other mine sites, where percent fines are low and coarse fragments tend to be higher (Sinnett et al., 2008). Particle size distribution and textural class for each site was previously determined by Marra et al. (2013). Hobet had an average percent sand of $63 \%, 27 \%$ silt, and $10 \%$ clay (Table 3.2 ). Hampshire had an average of $42 \%$ sand, $47 \%$ silt, and $11 \%$ clay (Table 3.2 ). Nutrient extraction results indicated that Hobet averaged higher nutrients for P and K (Table 3.3). Hampshire had higher nutrient contents for $\mathrm{Mg}$ and $\mathrm{Ca}$ (Table 3.3). Copper and $\mathrm{Ni}$ were present at both sites in equal amounts (Table 3.3). Zinc concentrations were higher at Hampshire than Hobet (1.2 $\mathrm{mg} \mathrm{kg}^{-1}$; Table 3.3). 
Table 3.2. Chemical and physical soil characteristics averaged for each site for 2015.

\begin{tabular}{ccc}
\hline Parameter & Hobet & Hampshire \\
\hline $\mathrm{pH}$ & 7.6 & 7.4 \\
$\mathrm{EC}\left(\mu \mathrm{S} \mathrm{cm}^{-1}\right)$ & 53 & 147 \\
\% Fines & 71 & 65 \\
\% Sand & 63 & 42 \\
\% Clay & 10 & 11 \\
\% Silt & 27 & 47 \\
\hline
\end{tabular}

Table 3.3. Values of extractable soil nutrients using Mehlich 1 solution at Hobet and Hampshire for 2015.

\begin{tabular}{ccc}
\hline Parameter & Hobet & Hampshire \\
\hline & $-----\mathrm{mg} \mathrm{kg}^{-1}------$ \\
$\mathrm{Al}$ & 6.8 & 21.6 \\
$\mathrm{Fe}$ & 4.1 & 1.1 \\
$\mathrm{Mn}$ & 7.6 & 7.5 \\
$\mathrm{Mg}$ & 30.4 & 31.9 \\
$\mathrm{Ca}$ & 89.0 & 388.3 \\
$\mathrm{~K}$ & 19.6 & 17.3 \\
$\mathrm{P}$ & 510.4 & 0.6 \\
$\mathrm{Cu}$ & 0.3 & 0.3 \\
$\mathrm{Zn}$ & 0.6 & 1.2 \\
$\mathrm{Ni}$ & 0.2 & 0.1 \\
\hline
\end{tabular}

Biomass results averaged over 2009 to 2015 for Hampshire and Hobet were significantly different (Table 3.4). The cultivar with the highest biomass yields at Hampshire was Cave-inRock followed by Shawnee, both of which produced significantly higher biomass yields than Carthage. Hobet, a much more compacted reclaimed mine site with no topsoil, had significantly lower biomass yields averaged from 2009 to 2015 (Table 3.4). These yields reflect the different reclamation practices that occurred. Hampshire had been reclaimed for almost 10 years before switchgrass was planted and the topsoil and amendments helped to prepare the mine soil for plant growth. Hobet, on the other hand, was a newly-reclaimed site, with no topsoil or amendments applied. 
Table 3.4. Switchgrass cultivar averages over years 2009 to 2015 at Hampshire and Hobet.

\begin{tabular}{lcc}
\hline Cultivar & Hampshire & Hobet \\
\hline & $-----\mathrm{Mg} \mathrm{ha}^{-1}------$ \\
Cave-in-Rock & $15.1^{\mathrm{a}}$ & $1.1^{\mathrm{c}}$ \\
Shawnee & $13.0^{\mathrm{a}}$ & $1.4^{\mathrm{c}}$ \\
Carthage & $6.0^{\mathrm{b}}$ & $1.3^{\mathrm{c}}$
\end{tabular}

Different letters denote a significant difference at $\mathrm{p}<0.05$ level of probability.

Averaged across all years and sites, the cultivar that produced the largest biomass yields was Cave-in-Rock (Table 3.5), although Shawnee had higher biomass than Cave-in-Rock in 2015. Statistical analysis showed that there was an interaction of site $\mathrm{x}$ year and cultivar $\mathrm{x}$ year $(p<0.05)$. A three-way interaction also existed with site $x$ cultivar $x$ year $(p>0.05)$. Biomass yield over time at Hampshire increased significantly while Hobet did not display a trend in biomass growth (Figure 3.4).

Table 3.5. Statistical significance and switchgrass biomass yields for main effect of site, cultivar, and year at Hampshire and Hobet.

\begin{tabular}{lcc}
\hline Effect & P $>\mathbf{F}$ & Yield \\
\hline Site & $<0.01$ & Mg ha $^{-1}$ \\
$\quad$ Hampshire & & 11.4 \\
Hobet & & 1.3 \\
Cultivar & 0.05 & \\
Cave-in-Rock & & $8.1^{\mathrm{a}}$ \\
Carthage & & $3.7^{\mathrm{b}}$ \\
Shawnee & & $7.2^{\mathrm{a}}$ \\
Year & $<0.01$ & \\
2009 & & $2.3^{\mathrm{c}}$ \\
2010 & & $4.2^{\mathrm{ab}}$ \\
2011 & & $3.0^{\mathrm{c}}$ \\
2012 & & $5.0^{\mathrm{ab}}$ \\
2013 & & $6.3^{\mathrm{ab}}$ \\
2014 & $8.0^{\mathrm{b}}$ \\
2015 & $15.5^{\mathrm{a}}$ \\
\hline
\end{tabular}


*Different letters denote significant difference within effects at $p<0.05$ level of probability according to Tukey's HSD. Untransformed means are reported.

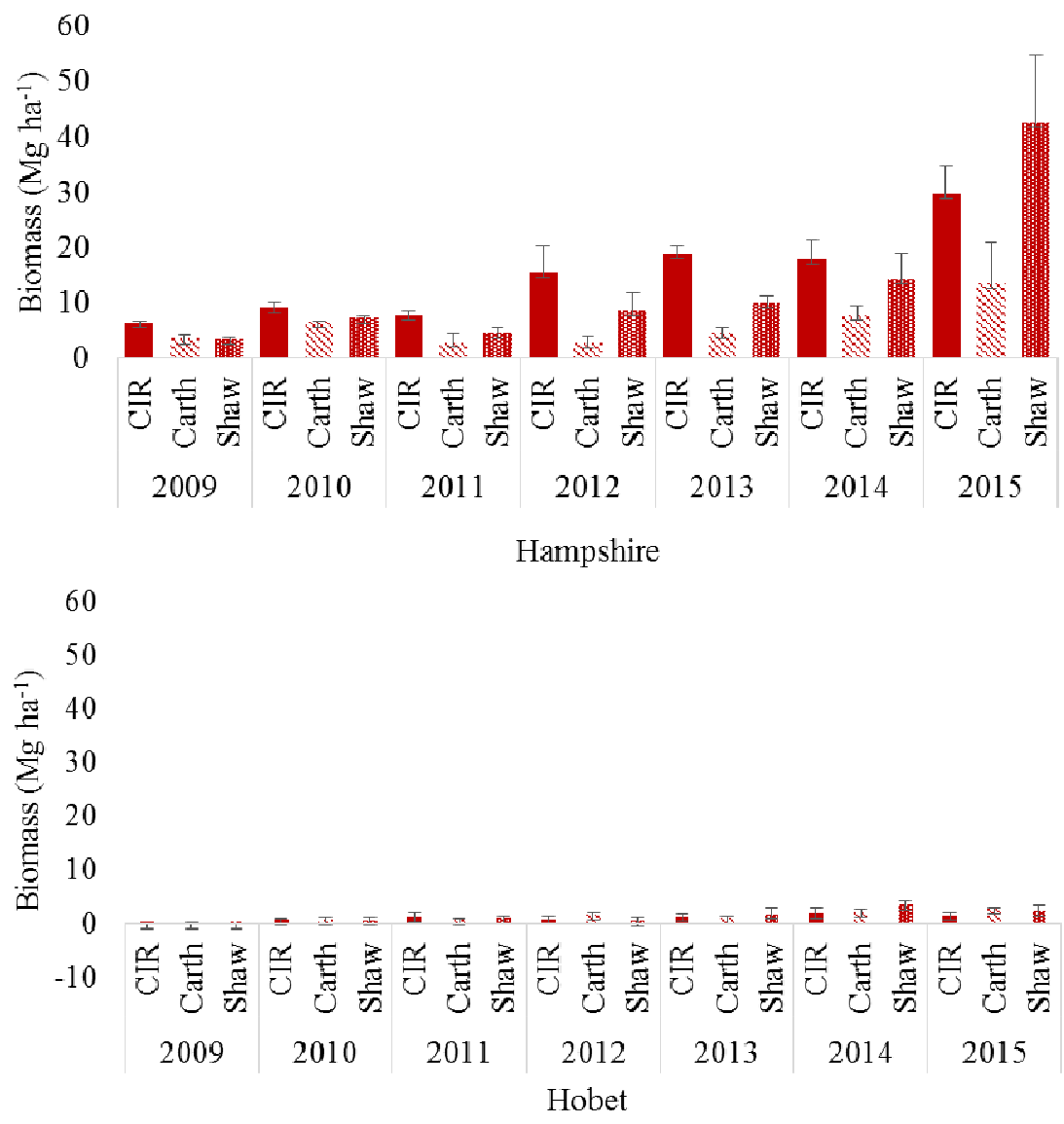

Figure 3.4. Yield of switchgrass cultivar averages from year 2009 to 2015 at Hampshire and Hobet.

\section{Conclusion}

Biomass yields can vary depending on cultivar. Selections for maximum yields should be based on climate, soil moisture, temperature, and production goals. Some studies have shown that upland cultivars tend to produce higher yields while other studies show that lowland species are higher producing. This study was conducted to identify which cultivar produced higher biomass yields on reclaimed mine sites in West Virginia. The site with the highest biomass 
production averaged from 2009 to 2015 was Hampshire (11.4 $\left.\mathrm{Mg} \mathrm{ha}^{-1}\right)$. Hampshire received soil amendment applications such as sewage and paper mill sludge before planting. Hobet biomass yield averaged from 2009 to 2015 was $1.3 \mathrm{Mg} \mathrm{ha}^{-1}$. The plots at Hobet received no fertilization application and no topsoil. The cultivar that yielded the highest biomass across all years and sites was usually Cave-in-Rock $\left(8.1 \mathrm{Mg} \mathrm{ha}^{-1}\right)$. This cultivar is an upland ecotype. Cultivar selection helps increase biomass yields but low establishment and stand yields can result if topsoil and amendments are not applied.

\section{Literature Cited}

Adkins, J., J.D. Jastrow, G.P. Morris, J. Six, M.A. de Graaff. 2016. Effects of switchgrass cultivars and intraspecific differences in root structure on soil carbon inputs and accumulation. Geoderma 262: 147-154.

Ashworth, A.J., P.D. Keyser, E.D. Holcomb, and C.A. Harper. 2014. Yield and stand persistence of switchgrass as affected by cutting height and variety. Forage and Grazing Lands. DOI 10.1094.

Brown, C. 2014. Biomass production, composition, and ethanol potential of switchgrass grown on reclaimed surface mines in West Virginia. M.S. thes., West Virginia Univ., West Virginia.

Christian, D.G. and H.W. Elbersen. 1998. Switchgrass (P. virgatum L.). Energy plant species. Their use and impact on environment and development. E. Bassam, London, James and James. 1: 257-263. 
Evanylo, G.K., A.O. Abaye, C. Dundas, C.E. Zipper, R. Lemus, B. Sukkariyah, and J.Rockett. 2005. Herbaceous vegetation productivity, persistence, and metal uptake on a biosolidsamended mine soil. J. Environ. Qual. 34: 1811-1819.

Hopkins, A.A., C.M. Taliaferro, and C.D. Christian. 1996. Chromosome number and nuclear DNA content of several switchgrass populations. Crop Sci. 36: 1192-1195.

Keene, T., and J. Skousen. 2010. Mine soil reclamation with switchgrass for biofuel production. p. 489-503. In: Proceedings, 2010 National Meeting of the American Society of Mining and Reclamation, Pittsburgh, PA, June 5-11, 2010. ASMR, Lexington, KY.

Lemus, R., E.C. Brummer, K.J. Moore, N.E. Molstad, C.L. Burras, and M.F. Barker. 2002. Biomass yield and quality of 20 switchgrass populations in southern Iowa, USA. Biomass Bioenerg. 23: 433-442.

Marra, M., and J. Skousen. 2012. Switchgrass potential on reclaimed surface mines for biofuel production in West Virginia. In: R.I. Barnhisel, (ed.), Proceedings, American Soc. Mining and Reclamation, Tupelo, MS, 8-15 June 2012.

Marra, M., T. Keene, J. Skousen, and T. Griggs. 2013. Switchgrass yield on reclaimed surface mines for bioenergy production. J. Environ. Qual. 42: 696-703.

McLaughlin, S.B. and L.A. Kszos. 2005. Development of switchgrass (Panicum virgatum) as a bioenergy feedstock in the United States. Biomass Bioenerg. 28: 515-535.

Mitchell, R., K.P. Vogel, and G. Sarath. 2008. Managing and enhancing switchgrass as a bioenergy feedstock. Biofuel. Bioprod. Bior. 2: 530-539. 
Monti, A., P. Venturi, and H.W. Elbersen. 2001. Evaluation of the establishment of lowland and upland switchgrass (Panicum virgatum L.) varieties under different tillage and seedbed conditions in northern Italy. Soil Till. Res. 63: 75-83.

Porter, C.L. 1966. An analysis of variation between upland and lowland switchgrass, Panicum virgatum L., in central Oklahoma. Ecology 47: 980-992.

Shapiro, S. S. and M.B. Wilk. 1965. An analysis of variance test for normality (complete samples). Biometrika 52: 591-611.

Sinnett, D., J. Poole, and T.R. Hutchings. 2008. A comparison of cultivation techniques for successful tree establishment on compacted soil. Forestry 81: 663-679.

Stroup, J.A., M.A. Sanderson, J.P. Muir, M.J. McFarland, and R.L. Reed. 2003. Comparison of growth and performance in upland and lowland switchgrass types to water and nitrogen stress. Bioresource Technol. 86: 65-72.

Sutton, P. and W.A. Dick. 1987. Reclamation of acidic mined lands in humid areas. Adv. Agron. 41: 377-405.

Weaver, J.E. and R. W. Darland. 1949. Soil-root relationships of certain native grasses in various soil types. Ecol. Monogr. 19: 303-338.

Wolf, A. and Beegle, D. 1995. Recommended soil tests for macronutrients: Phosphorus, Potassium, Calcium and Magnesium. p. 30-38. In: Sims, J.T. and A.M. Wolf (ed.). Recommended soil testing procedures for the Northeastern United States. Northeastern Regional Pub. No. 493 (2 ${ }^{\text {nd }}$ ed.). Agricultural Experiment Station Univ. of Delaware, Newark, DE. 
Wullschleger, S.D., E.B. Davis, M.E. Borsuk, C.A. Gunderson, and L.R. Lynd. 2010. Biomass production in switchgrass across the United States: Database description and determinants of yield. Agron. J. 102: 1158-1168. 


\section{CHAPTER 4: COMPARATIVE BIOMASS YIELDS OF MISCANTHUS AND SWITCHGRASS GROWN ON RECLAIMED MINE SITES IN WEST VIRGINIA AND OHIO}

\section{Introduction to Miscanthus}

Miscanthus is a warm-season perennial species that is native to eastern Asia, Northern India, and Africa (Clayton et al., 2008; Scally et al., 2001). Species of Miscanthus have been used as forages for grazing and structural materials in China and Japan for centuries (Stewart et al., 2009). Concerns over fossil fuel dependence beginning in the 1970s led to the evaluation of Miscanthus along with other species for its potential as a bioenergy crop (Heaton et al., 2010). Miscanthus is a genus comprising 14 to 20 species of perennial, C4 grasses (Clayton et al., 2008; Hodkinson et al., 2002). Miscanthus $x$ giganteus is a sterile hybrid between M. sinensis and $M$. sacchariflorus (Hopwood, 2010). It grows from rhizomes and can reach heights up to $3.5 \mathrm{~m}$ (Skousen et al., 2014) with dense rooting systems that extend down at least $2 \mathrm{~m}$ (Neukirchen et al., 1999). These dense and deep rooting systems can help break up compacted soils to improve structure and infiltration on marginal lands (Shrestha and Lal, 2009).

As a C4 species, its photosynthetic pathway has a high efficiency of water and nutrient use, typically requiring between 100 and $300 \mathrm{~L}$ of water to produce $1 \mathrm{~kg}$ of biomass (Beale et al., 1999; Lewandowski et al., 2000). For comparison with other biofuel crops, typical values for annual maize or sorghum are near the upper end of this range, around $300 \mathrm{~L}$ of water per $\mathrm{kg}^{-1}$ of whole plant biomass (Hanson and Hitz, 1983; Howell et al., 1998). Another advantage of perennial grasses in general is the ability to remobilize nutrients between aboveground and belowground tissues. Timing of senescence relative to harvest time is critical. Harvesting too soon can lead to increased nutrient concentrations in aboveground biomass which reduce quality of feedstocks for biofuel production due to nutrients becoming pollutants in fuel and removing 
nutrients from the site (Jenkins et al., 1998). Harvesting later in fall/early winter is ideal for reduced nutrient removal but harvesting so late tends to capture less of the overall biomass, sometimes equaling 30 to $50 \%$ of potentially harvestable DM (Clifton-Brown et al., 2007; Heaton et al., 2008). One benefit of fallen leaves is organic matter and nutrient cycling additions to improve soil quality.

Productivity of Miscanthus has been tested in field trials across Europe since the 1980s (Lewandowski et al., 2003). Most studies cover a 2- to 5-year growth period, but Miscanthus stands can remain productive for 15 to 30 years (Hasting et al., 2009; Heaton et al., 2004). Miscanthus could require $87 \%$ less land to produce the same amount of biomass as a low-input, high-diversity mixture of prairie species (Heaton et al., 2008). In some of the first replicated trials of Miscanthus in the United States, yield measurements were two- to four-fold higher than those of switchgrass variety Cave-In-Rock (Heaton et al., 2008). These same trials demonstrated average annual harvestable yields of $30 \mathrm{Mg} \mathrm{DM} \mathrm{ha}^{-1}$ without irrigation and only $25 \mathrm{~kg} \mathrm{ha}^{-1}$ of N fertilizer applied per growing season (Heaton et al., 2008). Another study done on marginal soil

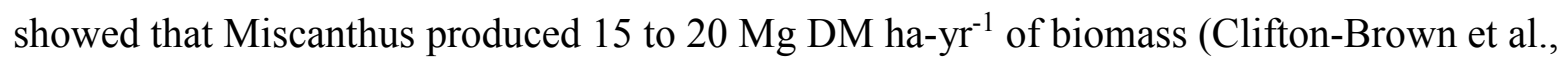
2007). Because of its high yields on marginal lands, Miscanthus is a promising bioenergy crop that is capable of being a sustainable solution to meet current energy demands.

\section{Miscanthus Biomass Production}

Increasing biomass production of Miscanthus depends on climate, soil, genetics, and management factors (Miguez et al., 2008). Growth patterns of Miscanthus can be evaluated across or within seasons (Miguez et al., 2008). Within a growing season, Miscanthus biomass accumulation normally peaks between August and October and then decreases due to senescence and leaf detachment (Miguez et al., 2008). 
In Europe, field trials have shown Miscanthus x giganteus reaching yields up to $40 \mathrm{Mg}$ ha $^{-1}$ (Lewandowski et al., 2000). Other studies have shown Miscanthus yields averaging up to 22 $\mathrm{Mg} \mathrm{ha}^{-1}$ annually (Heaton et al., 2004). Studies have also shown Miscanthus yields appearing consistent regardless of rainfall, nitrogen fertilizer or growing degree days (Heaton et al., 2004).

In a study done by Heaton et al. (2008), Miscanthus and switchgrass establishment and survival, relative DM production, and efficiency of interception and conversion of solar radiation to biomass were compared. This study reported that over the entire growing season, Miscanthus intercepted significantly more light than switchgrass $(\mathrm{P}<0.0001)$, dry matter per unit area was significantly greater $(\mathrm{P}<0.0001)$ for Miscanthus, peak dry biomass production was greater for Miscanthus, and Miscanthus produced the highest conversion efficiency. Overall, Miscanthus produced $40 \mathrm{Mg} \mathrm{ha}^{-1}$ averaged over the annual season (Heaton et al., 2008).

Nutrient requirements for maximum biomass production in Miscanthus were tested. Multiple studies have reported a positive growth response to $\mathrm{N}$ application when soils are Ndeficient (Boehmel et al., 2008; Clifton-Brown et al., 2007; Ercoli et al., 1999). Studies have also shown that when soils have a relatively high to medium N concentration initially, Miscanthus does not show a significant growth response with $\mathrm{N}$ application (Christian et al., 2008; Danalatos et al., 2007; Lewandowski and Heinz, 2003). In a study done by Lewandowski and Schmidt (2006), $\mathrm{N}$ was applied on various experimental sites and at various amounts taking into consideration the $\mathrm{N}$ provided by the soil at the beginning of the growing season. This study found that there was a positive response to $\mathrm{N}$ up to $110 \mathrm{~kg} \mathrm{ha}^{-1}$ (soil and fertilizer input) (Lewandowski and Schmidt, 2006). Minimum soil temperatures for Miscanthus to begin growth after winter dormancy is around 10 to $12^{\circ} \mathrm{C}$ (Clifton-Brown, 1997). 
The potential for Miscanthus to reach a full stand establishment typically takes 3-5 years. After stand establishment, biomass yield increases each year (Lewandowski et al., 2000). Genotypes differ in the amount of biomass that is produced from Miscanthus (Lewandowski et al., 1999; Hotz et al., 1996). Growth potential depends on the climatic region. Studies done in southern and central Europe have shown that Miscanthus $x$ giganteus is the most productive genotype for biomass production (Lewandowski et al., 1999).

\section{Miscanthus Management on Marginal Soils}

With increasing human population, concern over pollution from current energy sources, and need for available land, new ways are needed to harvest energy that will offset carbon emissions and not use land that is capable of producing crops for human consumption. Because of these current issues, alternative energy sources such as bioenergy production from herbaceous crop species are proposed and these crops can be grown in areas less suitable for food production. Because of its good growth and biomass yield, Miscanthus has been studied for growth on marginal lands.

Marginal lands have not attracted much attention from researchers until the recent increase in interest of growing bioenergy crops on these lands. Marginal lands can be described as lands that are poorly suited for field crops. They possess inherent soil or climatic limitations or they are located in areas that are vulnerable to erosion or other environmental risks when cultivated (Gelfand et al., 2013). Marginal lands are mostly suitable for grasses, short-rotation tree crops or other perennial vegetation with persistent roots that are better adapted to lownutrient, erodible or droughty soils (Gelfand et al., 2013).

Managing species on marginal lands can mean increasing nutrients, dealing with compaction issues and root restrictions, water infiltrations issues due to increased bulk density 
and so on. Selecting species that require less fertilization and maintenance and have deep rooting systems that can help improve soil quality by reducing compaction and increasing organic material are optimal.

Relatively little research exists on Miscanthus grown on marginal lands, especially reclaimed surface mine lands, for bioenergy production. Therefore, knowledge of Miscanthus management on marginal soils is also low. However, some studies have reported nutrient management of Miscanthus on marginal lands. A study done by Clifton-Brown et al. (2007), over a 15-year trial, showed the effects of fertilizer on biomass yields of Miscanthus grown on marginal land. This study showed that within the first two recorded years, there was no significant effect of $\mathrm{N}$ application rate on yield at time of harvest (Clifton-Brown et al., 2007). However, following a period of zero application, fertilizer addition to half of the plots for 5 years gave an overall significant yield increase of up to $4 \mathrm{Mg} \mathrm{DM} \mathrm{ha}^{-1}$ (Clifton-Brown et al., 2007). This might be due to the fact that once Miscanthus used up the $\mathrm{N}$ source from the soil and the biomass was removed from the site, plants were unable to obtain sufficient $\mathrm{N}$ for growth. Once fertilizer was reapplied, plants increased growth due to presence of $\mathrm{N}$.

Another management strategy for optimizing Miscanthus growth on marginal soils is harvest time. Miscanthus is a $\mathrm{C} 4$ perennial species; therefore, it remobilizes nutrients from aboveground to belowground tissues depending on the season. If harvest occurs before remobilization of nutrients to belowground tissues, significant nutrients can be removed from the site. In a study done by Clifton-Brown et al. (2007), sampling time had a statistically significant impact on all nutrients measured. This study showed that early harvesting resulted in substantial nutrient removal $\left(145 \pm 9.4 \mathrm{~kg} \mathrm{~N} \mathrm{ha}^{-1}, 23 \pm 1.1 \mathrm{~kg} \mathrm{P} \mathrm{ha}^{-1}\right.$, and $\left.111 \pm 9.9 \mathrm{~kg} \mathrm{~K} \mathrm{ha}^{-1}\right)$. Delaying 
harvest until March reduced these removals to $51 \pm 6.1 \mathrm{~kg} \mathrm{~N} \mathrm{ha}^{-1}, 8.3 \pm 0.7 \mathrm{~kg} \mathrm{P} \mathrm{ha}^{-1}$, and $42 \pm$ $7.9 \mathrm{~kg} \mathrm{~K} \mathrm{ha}^{-1}$ (Clifton-Brown et al., 2007).

\section{Study Objectives}

The objective of this study was to determine biomass yields of switchgrass and Miscanthus cultivars on reclaimed mine lands. On one site, two cultivars of switchgrass (Kanlow and BoMaster) and two varieties of Miscanthus (Public and Private) were compared 6 years after establishment. At two different sites, biomass yields of Cave-in-Rock switchgrass and Miscanthus $x$ giganteus were compared after 3 and 4 years of establishment. Based off of previous findings at these sites and current literature on both species, Miscanthus will produce higher biomass yields than switchgrass on these sites.

\section{Materials and Methods}

\section{Site Location}

Three sites were established for this study: The Wilds, MeadWestvaco, and Alton. The Wilds is located on nearly 4,000 ha of reclaimed surface mined land in Cumberland, Ohio $\left(39.83^{\circ} \mathrm{N}, 81.73^{\circ} \mathrm{W}\right)$. Part of this site includes reclamation to native grass prairies, including grasses used for bioenergy production such as switchgrass and Miscanthus. Soils were composed of dumped overburden material that was graded to approximate contour. A cool-season grasslegume mix of tall fescue (Schedonorus arundinaceus (Schreb.) Dumort., nom. cons..), orchardgrass (Dactylis glomerata L), and clovers (Trifolium spp.) were seeded. The area was mowed during succeeding decades and soil has developed over time with accumulation of organic matter that helped to re-establish an organic matter pool and nutrient cycles. In April 2013, the existing vegetation was killed with glyphosate herbicide at recommended rates. 
Certified Cave-in-Rock switchgrass seed was drilled into the killed sod on June 6, 2013 at a rate of $12 \mathrm{~kg} \mathrm{PLS} \mathrm{ha}^{-1}$.

MeadWestvaco (MWV) was a previously surface mined area located in Greenbrier County, WV $\left(38.03^{\circ} \mathrm{N}, 80.65^{\circ} \mathrm{W}\right)$. MWV had been reclaimed for approximately 10 years before switchgrass and Miscanthus were planted (Skousen et al., 2014). The existing cool-season vegetation was killed with glyphosate herbicide in April 2013 and drilled with certified Cave-inRock switchgrass at $12 \mathrm{~kg} \mathrm{PLS} \mathrm{ha}{ }^{-1}$.

Alton is a previously surface-mined area of approximately 160 ha located in Upshur County, WV $\left(38.49^{\circ} \mathrm{N}, 80.11^{\circ} \mathrm{W}\right)$. This site was mined for the Upper, Middle, and Lower Kittanning coal seams. Coal was mined using truck-shovel equipment spreaders. The 30 -ha area selected for switchgrass and Miscanthus plantings was reclaimed in 1985 with less than $15 \mathrm{~cm}$ depth of soil replaced over mixed overburden. Grass and legume species were planted and the soils were fertilized and limed according to regulations at the time. This site supported a $100 \%$ ground cover of herbaceous plants during the ensuing 25 years. The ground cover was killed with glyphosate herbicide before seeding and sprigging.

\section{Treatments and Experimental Design}

An 8-ha area was selected for switchgrass and Miscanthus planting at The Wilds and MeadWestvaco. Miscanthus rhizomes were planted on $0.9-\mathrm{m}$ centers in a grid pattern. The 8-ha switchgrass plot was divided into three sections corresponding to aspect and slope. Biomass clippings have been taken annually.

At Alton, a randomized complete block design was used to evaluate two cultivars of switchgrass (Kanlow and BoMaster, supplied by Ernst Conservation Seeds) and two varieties of Miscanthus (Private and Public, supplied by Mendel Biotechnology) with five replications. 
Twenty 0.4-ha plots were randomly assigned one of the species and varieties. Switchgrass seed was drilled into killed sod with an agricultural sod-seeding drill at the rate of $11 \mathrm{~kg} \mathrm{PLS} \mathrm{ha}^{-1}$. Sterile varieties of Miscanthus sprigs were planted at a rate of 12,300 plugs ha $^{-1}$ (0.9-m spacing in grid pattern) (Skousen et al., 2014).

\section{Vegetation Sampling}

Six biomass samples were collected from each experimental unit in $0.21-\mathrm{m}^{2}$ quadrats.

Sample locations were previously decided from a random-number generator. Samples were taken at the post-anthesis stage of switchgrass growth in October. All switchgrass within the quadrat was clipped to a stubble height of approximately $10 \mathrm{~cm}$. Because Miscanthus was planted on 0.9m spacings, each plant was taken for sampling. No other plants were included for analysis. The biomass samples were then taken back to the lab and oven dried at $60^{\circ} \mathrm{C}$ to a constant weight (Sluiter et al., 2013) to determine dry weight.

\section{Soil Sampling}

Three soil samples were collected from each plot. Soil samples were collected by taking a shovel slice to approximately 15 -cm depth and analyzed for percent fines, $\mathrm{pH}, \mathrm{EC}, \mathrm{Al}, \mathrm{Fe}, \mathrm{Mn}$, $\mathrm{Mg}, \mathrm{Ca}, \mathrm{K}, \mathrm{P}, \mathrm{Ni}, \mathrm{Cu}$, and $\mathrm{Zn}$. Soil samples were then air-dried and sieved to obtain a soil sample composed of $\leq 2 \mathrm{~mm}$-sized material (fine fraction). The fine fraction was then used for chemical analysis. To determine $\mathrm{pH}, 5 \mathrm{~g}$ of soil was combined with $5 \mathrm{~mL}$ of distilled de-ionized water, mixed for 15 minutes, equilibrated for one hour, and then $\mathrm{pH}$ readings were taken using a $\mathrm{pH}$ Meter. EC readings were taken using a conductivity meter. Percent fines were determined from weights of whole soil and fractions. Mehlich 1 solution was used to extract available elements from the soil using inductively coupled plasma mass spectrometry (ICP) analysis ( $\mathrm{Al}, \mathrm{Fe}, \mathrm{Mn}$, $\mathrm{Mg}, \mathrm{Ca}, \mathrm{K}, \mathrm{P}, \mathrm{Ni}, \mathrm{Cu}$, and $\mathrm{Zn}$ ) (Wolf and Beegle, 1995). 


\section{Statistical Analysis}

The biomass at Alton was analyzed separately from MWV and The Wilds. The treatment arrangement for Alton followed a nested design, with the two species (switchgrass, Miscanthus) and two cultivars within each species (Kanlow and BoMaster within switchgrass; Public and Private within Miscanthus). The Ln-transformed biomass data were analyzed for all 5 years using repeated measures ANOVA in PROC MIXED of SAS with year being a repeated factor (SAS Institute Inc., Cary, NC, Copyright (C2013; SAS®, Version 9.3, SAS Institute Inc., Cary, NC, Copyright (C2002-2010). Main fixed effects were species and cultivar within a species. Random factors were year and plot.

Data from MWV and The Wilds were arranged in a randomized block design with MWV and The Wilds being random blocks. The species (switchgrass, Miscanthus) represented a fixed effect and year as a repeated factor in repeated measures ANOVA of PROC MIXED of SAS. Statistical significance was based on a P-value of $\leq 0.05$.

\section{Results and Discussion}

Soil $\mathrm{pH}$ for Alton, MeadWestvaco (MWV), and The Wilds ranged from 5.6 at MWV to 6.9 at Alton (Table 4.1). All pH's are within the range to support Miscanthus and switchgrass growth. Electrical conductivity for MWV was the lowest at $69 \mu \mathrm{S} \mathrm{cm}^{-1}$ and the highest at Alton $\left(106 \mu \mathrm{S} \mathrm{cm}^{-1}\right)$. Percent fines were higher than expected for reclaimed mine sites, but all of these sites have had more soil development than sites that were recently disturbed (Table 4.1).

Extractable soil nutrients for 2015 showed low iron, copper, zinc, and nickel concentrations, but high calcium and phosphorus concentrations (Table 4.2). Soils at these sites were within an acceptable range for switchgrass and Miscanthus to grow. 
Table 4.1. Chemical and physical soil characteristics averaged for each site for 2015.

\begin{tabular}{cccc}
\hline Parameter & Alton & MWV & The Wilds \\
\hline $\mathrm{pH}$ & 6.9 & 5.6 & 6.3 \\
$\mathrm{EC}\left(\mu \mathrm{S} \mathrm{cm}^{-1}\right)$ & 106 & 69 & 96 \\
$\%$ Fines & 64 & 64 & 64 \\
\hline
\end{tabular}

Table 4.2. Values of extractable soil nutrients using Mehlich 1 solution for 2015.

\begin{tabular}{cccc}
\hline Parameter & Alton & MWV & The Wilds \\
\hline & $------\mathrm{mg} \mathrm{kg}^{-1}$ & ------ \\
$\mathrm{Al}$ & 21.4 & 10.5 & 17.8 \\
$\mathrm{Fe}$ & 7.1 & 5.2 & 1.3 \\
$\mathrm{Mn}$ & 7.2 & 12.2 & 6.9 \\
$\mathrm{Mg}$ & 19.8 & 52.7 & 73.6 \\
$\mathrm{Ca}$ & 392.8 & 209.0 & 452.1 \\
$\mathrm{~K}$ & 21.6 & 63.6 & 47.1 \\
$\mathrm{P}$ & 256.8 & 122.6 & 75.5 \\
$\mathrm{Cu}$ & 0.3 & 0.3 & 0.1 \\
$\mathrm{Zn}$ & 0.5 & 1.8 & 0.1 \\
$\mathrm{Ni}$ & 0.2 & 0.6 & 0.1 \\
\hline
\end{tabular}

Biomass results for Alton show that Miscanthus produced higher biomass yields than switchgrass, but the differences were not significant. Switchgrass cultivars, Kanlow and BoMaster averaged 5.7 and 5.8 $\mathrm{Mg} \mathrm{ha}^{-1}(\mathrm{p}<0.05)$ (Table 4.3). Biomass for Miscanthus varieties, Public and Private, were not significantly different $(\mathrm{p}<0.05)$ (Table 4.3). When species were averaged each year, there was a significant difference between 2011, the first year biomass was recorded after stand establishment, and years 2014 and 2015 (Table 4.3). When considering species selection for bioenergy production based on yields, Miscanthus produced greater yields of biomass than switchgrass. 
Table 4.3. Statistical significance for main effect of species, cultivar, and year for biomass yields at Alton.

\begin{tabular}{|c|c|c|c|}
\hline \multirow{2}{*}{\multicolumn{2}{|c|}{ Effect }} & $P>F$ & Yield \\
\hline & & & $\mathrm{Mg} \mathrm{ha}^{-1}$ \\
\hline \multirow[t]{3}{*}{ Species } & & 0.07 & \\
\hline & Switchgrass & & 5.8 \\
\hline & Miscanthus & & 9.7 \\
\hline \multirow[t]{3}{*}{$\begin{array}{r}\text { Cultivar } \\
\mathrm{Sw}\end{array}$} & chgrass & 0.12 & \\
\hline & Kanlow & & 5.8 \\
\hline & BoMaster & & 5.7 \\
\hline \multicolumn{4}{|c|}{ Miscanthus } \\
\hline & Public & & 7.3 \\
\hline & Private & & 12.2 \\
\hline \multirow[t]{6}{*}{ Year } & & $<0.01$ & \\
\hline & 2011 & & $4.2^{\mathrm{a}}$ \\
\hline & 2012 & & $7.3^{\mathrm{ab}}$ \\
\hline & 2013 & & $7.1^{\mathrm{ab}}$ \\
\hline & 2014 & & $10.8^{\mathrm{b}}$ \\
\hline & 2015 & & $9.5^{\mathrm{b}}$ \\
\hline
\end{tabular}

*Different letters denote significant difference within effects at $\mathrm{P}<0.01$ according to Tukey's HSD. Transformed means are reported.

The Wilds produced higher biomass yields than MeadWestvaco averaged across species and years (Table 4.4). When averaged over sites, species, and years, switchgrass produced significantly higher yields than Miscanthus. When averaged across species and sites, biomass yields were significantly higher in 2015 than 2014.

Studies have shown Miscanthus produces greater yields of biomass than switchgrass. Switchgrass and Miscanthus typically take 3 years to reach full stand establishment. It is expected that Miscanthus will probably produce greater biomass yields than switchgrass as has been shown by others as more time passes. 
Table 4.4. MeadWestvaco and The Wilds statistical significance biomass yields for main effect of site, species, and year.

\begin{tabular}{|c|c|c|}
\hline Effect & $\mathbf{P}>\mathbf{F}$ & Yield \\
\hline & & $\mathrm{Mg} \mathrm{ha}^{-1}$ \\
\hline Site & 0.01 & \\
\hline MeadWestvaco & & 3.1 \\
\hline The Wilds & & 5.7 \\
\hline Species & 0.03 & \\
\hline Switchgrass & & 6.2 \\
\hline Miscanthus & & 2.6 \\
\hline Year & 0.04 & \\
\hline 2014 & & 3.4 \\
\hline 2015 & & 5.4 \\
\hline
\end{tabular}

Untransformed means are reported.

\section{Conclusion}

Miscanthus has been considered as an alternative to switchgrass for bioenergy production. Studies have shown that Miscanthus is capable of producing large amounts of biomass on less land required for corn grain and switchgrass. The objective of this study was to observe the yield potential of Miscanthus and switchgrass on three reclaimed mine sites to determine which species are capable of producing greater biomass yields and also to test how both species establish on reclaimed mine sites. The study conducted at Alton showed that Miscanthus produced more biomass than switchgrass after 6 years of establishment. Alton averaged 9.6 $\mathrm{Mg} \mathrm{ha}^{-1}$ for Miscanthus and 5.8 $\mathrm{Mg} \mathrm{ha}^{-1}$ for switchgrass. Yields of biomass across species and years were higher at The Wilds $\left(5.7 \mathrm{Mg} \mathrm{ha}^{-1}\right)$ than at MeadWestvaco $\left(3.1 \mathrm{Mg} \mathrm{ha}^{-1}\right)$. Yield of Miscanthus averaged across years and sites was significantly lower than switchgrass (2.6 $\mathrm{Mg} \mathrm{ha}^{-1}$ and 6.2 $\mathrm{Mg} \mathrm{ha}^{-1}$, respectively). Because switchgrass and Miscanthus take 3 to 5 years to fully establish, Miscanthus could still produce higher biomass yields than switchgrass in the future. 


\section{Literature Cited}

Beale, C.V., J.I.L. Morison, and S.P. Long. 1999. Water use efficiency of C4 perennial grasses in a temperate climate. Agr. Forest Meteorol. 96: 103-115.

Boehmel, C., I. Lewandowski, and W. Claupein. 2008. Comparing annual and perennial energy cropping systems with different management intensities. Agr. Syst. 96: 224-236.

Christian, D.G., A.B. Riche, and N.E. Yates. 2008. Growth, yield and mineral content of Miscanthus $x$ giganteus grown as a biofuel for 14 successive harvests. Ind. Crop Prod. 28: $320-327$.

Clayton, W.D., K.T. Harman, and H. Williamson. 2008. GrassBase-The online world grass flora royal botanic gardens. Kew. http://www.kew.org/data/grasses-db.html.

Clifton-Brown, J.C. 1997. The importance of temperature in controlling leaf growth of Miscanthus in temperate climates. Ph.D. thesis, Trinity College Dublin.

Clifton-Brown, J.C., J. Breuer, and M.B. Jones. 2007. Carbon mitigation by the energy crop Miscanthus. Glob. Change Biol. 13: 2296-2307.

Danalatos, N.G., S.V. Archontoulis, and I. Mitsios. 2007. Potential growth and biomass productivity of Miscanthus $x$ giganteus as affected by plant density and $\mathrm{N}$-fertilization in central Greece. Biomass Bioenerg. 31: 145-152.

Ercoli, L., M. Mariotti, A. Masoni, and E. Bonari. 1999. Effect of irrigation and nitrogen fertilization on biomass yield and efficiency of energy use in crop production of Miscanthus. Field Crop Res. 63: 3-11.

Gelfand, I., R. Sahajpal, X. Zhang, R.C. Izaurralde, and K.L. Gross. 2013. Sustainable bioenergy production from marginal lands in the US Midwest. Nature 493: 514-517. 
Hanson, A.D., and W.D. Hitz. 1983. Whole-plant response to water deficits: Water deficits and the nitrogen economy. pp. 331-344. In: Limitations to efficient water use in crop production. Taylor, H.M., W.R. Jordan, and T.R. Sinclair (ed.). ASA-CSSA-SSA, Madison, WI.

Hasting, A., J. Clifton-Brown, M. Wattenbach, C.P. Mitchell, P. Stampfl, and P. Smith. 2009. Future energy potential of Miscanthus in Europe. Global Change Biology. Bioenergy 1: 180-196.

Heaton, E.A., J. Clifton-Brown, T.B. Voigt, M.B. Jones, and S.P. Long. 2004. Miscanthus for a renewable energy generation: European Union experience and projections for Illinois. Mitigation Adaptation Strat. Glob. Change 9: 433-451.

Heaton, E.A., T.B. Voigt, S.P. Long. 2004. A quantitative review comparing the yields of two candidate $\mathrm{C}-4$ perennial biomass crops in relation to nitrogen, temperature and water. Biomass Bioenerg. 27: 21-30.

Heaton, E.A., F.G. Dohleman, and S.P. Long. 2008. Meeting U.S. biofuel goals with less land: The potential of Miscanthus. Glob. Change Biol. 14: 2000-2014.

Heaton, E.A., N.N. Boersma, J.D. Caveny, T.B. Voigt, and F.G. Dohleman. 2010. Miscanthus for biofuel production. Extension Bioenergy Feedstock Community of Practice. http://www.extension.org/pages/Miscanthus for biofuel production. Accessed September, 2015.

Hodkinson, T.R., M.W. Chase, M.D. Lledo, N. Salamin, and S.A. Renvoize. 2002. Phylogenetics of Miscanthus, Saccharum and related genera (Saccharinae, Andropogoneae, Poacea) 
based on DNA sequences from ITS nuclear robisomal DNA and plastid trnL intron and trnL-F intergenic spacers. J. Plant Res. 115: 381-392.

Hopwood, L. 2010. NNFCC Crop Factsheet: Miscanthus. The Bioeconomy Consultants: http://www.nnfcc.co.uk/publications/nnfcc-crop-factsheet-miscanthus. Accessed September, 2015.

Hotz, A., W. Kuhn, and S. Jodl. 1996. Screening of different Miscanthus cultivars in respect of yield production and usability as a raw material for energy and industry. p. 523-527. In: Chartier, P., G.L. Ferrero, U.M. Henius, S. Hultberg, J. Sachau, and M. Wiinblad, (editors). Biomass for Energy and the Environment: Proceedings of the Ninth European Bioenergy Conference, Copenhagen, Denmark, 24-27 June 1996. New York: Pergamon.

Howell, T.A., J.A. Tolk, A.D. Schneider, and S.R. Evett. 1998. Evapotranspiration, yield, and water use efficiency of corn hybrids differing in maturity. Agron. J. 90: 3-9.

Jenkins, B.M., L.L. Baxter, and T.R. Miles. 1998. Combustion properties of biomass. Fuel Process. Technol. 54: 17-46.

Lewandowski, I., J.C. Clifton-Brown, M. Deuter. 1999. Potential of Miscanthus genotypes in Europe: over-wintering and yields. p. 46-52. In: Mela T., J. Christiansen, M. Kontturi, K. Pahkala, A. Partala, M. Sahramaa, H. Sankari, M. Topi-Hulmi, and K. Pithan, (editors). Alternative Crops for Sustainable Agriculture. European Commission, BioCity, Turku, Finland.

Lewandowski, I. and A. Heinz. 2003. Delayed harvest of Miscanthus-Influences on biomass quantity and quality and environmental impacts of energy production. Eur. J. of Ag. 19: 45-63. 
Lewandowski, I. and U. Schmidt. 2006. Nitrogen, energy and land use efficiencies of Miscanthus, reed canary grass and triticale as determined by the boundary line approach. Agr. Ecosyst. Environ. 112: 335-346.

Miguez, F.E., M.B. Villamil, S.P. Long, and G.A. Bollero. 2008. Meta-analysis of the effects of management factors on Miscanthus $x$ giganteus growth and biomass production. Agr. Forest Meteorol. 148: 1280-1292.

Neukirchen, D., M. Himken, J. Lammel, U. Czypionka Krause, and H.W. Olfs. 1999. Spatial and temporal distribution of the root system and root nutrient content of an established Miscanthus crop. Eur. J. of Ag. 11: 301-309.

Scally, L., T.R. Hodkinson, and M.B. Jones. 2001. Origins and taxonomy of Miscanthus. In: Miscanthus for energy and fiber. Jones, M.B. and M. Walsh. James \& James (ed.), London.

Shrestha, R. and R. Lal. 2009. Offsetting carbon dioxide emissions through minesoil reclamation. Climate adaption mitigation e-learning (CAMEL). Retrieved from http://www.eoearth.org/view/article/154999. Accessed September, 2015.

Skousen, J., C.B. Brown, T. Griggs, and S. Byrd. 2014. Establishment and growth of switchgrass and other biomass crops on surface mines. 3(1): p. 136-156. In: American Society of Mining and Reclamation J. R. Darmody (ed.), Oklahoma City, OK.

Stewart, J.R., Y. Toma, F.G. Fernandez, A. Nishiwaki, T. Yamada, and G.A. Bollero. 2009. The ecology and agronomy of Miscanthus sinensis, a species important to bioenergy crop development, in its native range in Japan: A review. Global change biology. Bioenergy 1: 126-153. 


\section{CHAPTER 5: THEORETICAL YIELD (L MG $\left.{ }^{-1}\right)$ AND PRODUCTION (L HA $^{-1}$ ) OF ETHANOL FROM SWITCHGRASS AND MISCANTHUS ON RECLAIMED MINE SITES IN WEST VIRGINIA AND OHIO}

\section{Introduction to Near-Infrared Reflectance Spectroscopy}

Quantifying the actual and theoretical yields of ethanol from biochemical conversion requires expensive and complex assays (Corson et al., 1999). Fast, inexpensive methods with high accuracy are needed to predict ethanol yields (Vogel et al., 2011). Near-infrared reflectance spectroscopy (NIRS) is an instrumental method for rapidly measuring the chemical composition of the organic fraction of samples (Norris, 1976), and from which theoretical ethanol yields can be predicted with little sample preparation. The near-infrared (NIR) wavelength region of the electromagnetic spectrum extends from the red end of the visible wavelength region at $800 \mathrm{~nm}$ to $2500 \mathrm{~nm}$. This range is the start of the traditional mid-infrared (mid-IR) region involved in identifying compounds by their characteristic functional group absorptions (Murray, 1993). The NIR spectra of forages are dominated by absorptions due to the hydrogen-bearing functional groups - $\mathrm{CH},-\mathrm{OH}$, and - $\mathrm{NH}$ (Murray, 1986) The low mass of the hydrogen atom results in a greater likelihood of overtones and combinations of the fundamental stretching and bending absorptions which take place in the mid-IR region (Murray, 1986). The first overtone of $-\mathrm{CH}$ stretching occurs at nearly half the wavelength of the fundamental while the second overtone occurs at nearly one third of the wavelength of the fundamental. The intensity of each successive overtone gets progressively weaker compared with the fundamental by a factor of 10 to 100 (Murray, 1993). Deeper sample penetration will occur in the NIR than in the mid-IR.

A NIR spectrometer consists of three parts: a near-infrared source (lamp), a wavelength isolator, and a detector (Tsuchikawa, 2007). The lamp and isolator transmit near-infrared light in wavelengths to the sample, the detector senses extent of reflectance or transmission of individual 
wavelengths through the sample, and then a computer processes the information to make a spectrum (Figure 5.1). Because the molecular functional groups of forage samples absorb NIR light differently, samples with varying functional groups produce differing absorption spectra (Murray, 1993). Early research found that NIRS provided an easy way to measure moisture in forages because water absorbs strongly in the NIR region (Murray, 1993). NIRS is able to detect the structural materials that make up cell walls in plants such as hemicellulose, cellulose, and lignin because they contain hydrogen-bearing functional groups.

Conversion to ethanol requires the complex plant cell wall structure to be broken down in order for enzymes to access the fermentable sugars. This requires initial pre-treatment of the biomass either mechanically, thermally, or chemically to expose the carbohydrates (Vogel et al., 2011). After pretreatment, carbohydrates are hydrolyzed by enzymes and then hexose and pentose sugars are fermented into ethanol with the use of microorganisms (Vogel et al., 2011).

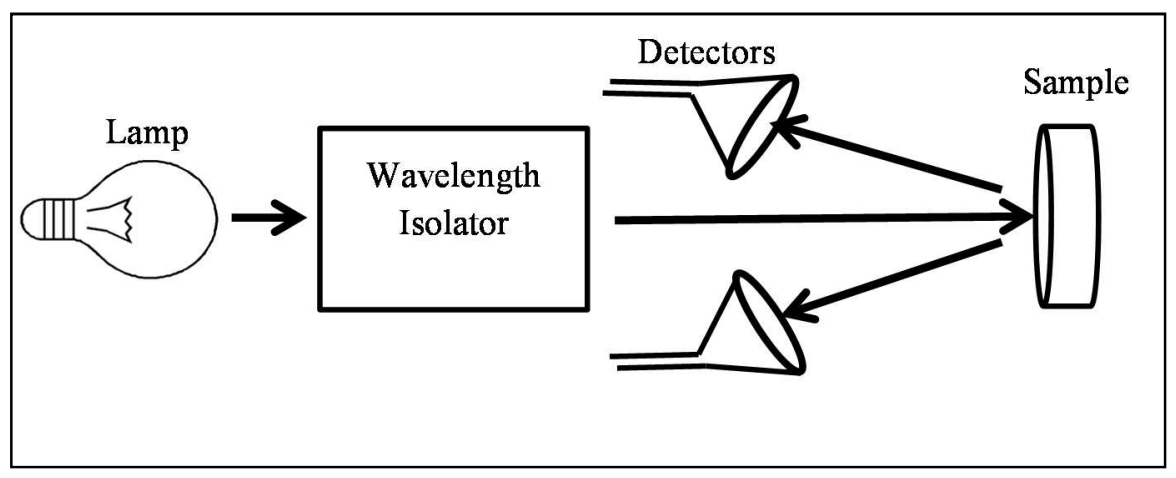

Figure 5.1. Simplified NIRS example (McClure and Tsuchikawa, 2007).

Wet chemistry is used to determine the constituents present in the samples and the values from chemical analyses are then correlated to NIRS spectra. Chemometrics software is used to find patterns between spectra and chemical composition, and to calibrate to determine 
constituent concentrations. Mathematical and statistical procedures are used to develop and validate prediction equations (Vogel et al., 2011).

The NIRS method has four main advantages: speed, simplicity of sample preparation, multiplicity of analysis with one operation, and reuse capability of samples with little to no lab waste disposal or pollution potential (Norris, 1976). Although the initial cost of a NIR spectrometer instrument is expensive, the device provides a cost-effective, non-destructive means to test a wide-range of constituents from one sample (Williams, 2007).

\section{Wet Chemistry Analysis}

While using a faster approach, such as NIRS, to predict forage constituents used for ethanol production is preferred, wet chemical analysis of samples is needed to determine accurate measurements of constituents used in constructing prediction models and equations. Determining the chemical constituents in forages using wet chemistry is very costly. Laboratories can charge from $\$ 250$ to $\$ 2000$ per sample (Hames et al., 2003; Complex Carbohydrate Research Center, 2015) due to the time, equipment, and materials required to analyze each sample. Because wet chemical analysis is so expensive and time consuming, it is not recommended for commercial ethanol production plants. Typical analytical measurements include neutral detergent fiber (NDF), acid detergent fiber (ADF), ash, protein, extractives, structural carbohydrates and lignin, and starch (Sluiter et al., 2013). There are different ways to extract each constituent and each constituent is generally extracted separately. Multiple procedures can be found in National Renewable Energy Laboratory (NREL) analytical procedures (LAP) (NREL, 2016). The main goal of the LAPs is to break down the biomass sample into constituents that sum up to $100 \%$ by weight (Sluiter et al., 2013). Monono et al. (2013) analyzed biomass samples were analyzed using the NREL LAPs to determine 
constituents. Non-structural components such as chlorophyll, waxes, and other minor components were removed with $95 \%$ ethanol using a solvent extractor set at $100^{\circ} \mathrm{C}$ and 10.3 MPa for 5 minutes heating time and 7 minutes static time. Dried extractives-free biomass samples were hydrolyzed in $72 \%$ sulfuric acid at $30^{\circ} \mathrm{C}$ for 1 hour (Monono et al., 2013). Sugar concentrations were obtained using HPLC with an Aminex HPX-87P carbohydrate column running at $85^{\circ} \mathrm{C}$, sugar peaks were detected by a refractive index detector at $50^{\circ} \mathrm{C}$ and quantified using 4-point external standard curves (Monono et al., 2013). Other constituents, such as ash, can be measured using ignition methods such as igniting samples in a muffle furnace set to $575^{\circ} \mathrm{C}$ with pre-ignition or using a ramping muffle furnace with no pre-ignition (Sluiter et al., 2013). Since wet chemistry analysis is very time consuming and costly, NIRS is becoming more prevalent for use at a larger production scale such as at bio-refineries.

\section{Switchgrass and Miscanthus Biofeedstock Quality}

Biomass composition affects its value for conversion to energy. The three major constituents of cell walls for biofuel conversion efficiency are cellulose, hemicellulose, and lignin. Lignin can be described as the "glue" that holds biomass components together. It is a physical barrier and complex polymer that differs in formation among plants depending on alcohol types used in formation (Huber et al., 2006). The most basic component of lignin is phenyl propane. Cellulose is a homo-polymer comprised of repeating glucose monomers. Cellulose is rigid and provides strength to cell walls which makes it difficult to break down depending on lignification. This strength comes from glucose connected with $\beta-(1,4)$ bonds (Huber et al., 2006). Hemicellulose is a hetero-polymer comprised of pentose and hexose sugars. The pentoses (C5 sugars) are xylose and arabinose (Huber et al., 2006). The hexoses (C6 sugars) are glucose, galactose, and mannose (Huber et al., 2006). Cellulose and hemicellulose are 
carbohydrate polymers which are bound to lignin by hydrogen bonding and some covalent bonds (Lee, 1997). The complexity of ligno-cellulosic material increases the difficulty of enzymatic degradation to fermentable sugars (Gray et al., 2006).

Quality will be greater in feedstocks with decreased lignin and inorganic metal constituents and increased carbohydrate fractions (Fahmi et al., 2007; Vogel et al., 2011). Glucose, mannose, and xylose compose about 95 to $97 \%$ of the total sugars in ligno-cellulosic biomass (Dwivedi et al., 2009). An ethanol conversion calculation can be used to predict ethanol yields using the C6 sugars (mannose, galactose, glucose) and the C5 sugars (arabinose and xylose), the major fermentable sugars in biomass (Dien, 2010).

Quality of biomass can vary spatially due to precipitation, management, and/or temperature fluctuations and climatic regions (Schmer et al., 2012; Jiang et al., 2012; Adler et al., 2006). Studies have shown that cultivars can also vary in composition of lingo-cellulose (Adler et al., 2009; David and Ragauskas, 2010; Monono et al., 2013; Schmer et al., 2012). Schmer et al. (2012) reported that Cave-in-Rock (CIR) and Shawnee switchgrass cultivars had greater concentrations of hexoses than Trailblazer switchgrass cultivar.

\section{Biomass Conversion Technologies}

Fermentation to fuels involves breaking down biofuels to structurally less complex organic residues that are then enzymatically converted to sugars and then fermented by microbes to ethanol (McLaughlin et al., 1999). This process is very expensive due to finding, creating, and optimizing microbial communities that can digest this material and also the acids used in breaking down the lignin within the biomass (McLaughlin et al., 1999). Acid pretreatment is used to break down the structural and chemical composition of lignin and cellulose in order to rapidly and efficiently hydrolyze carbohydrates into fermentable sugars (Han et al., 2011). After 
pretreatment, enzymes that can ferment hexose and pentose sugars are used to hydrolyze carbohydrates and ferment them into ethanol (Vogel et al., 2011). Biochemical conversion of lignocellulose to ethanol has been evaluated as the best option thus far with regards to commercial production (Dien, 2010). Steps for biochemical conversion can be simplified as: pretreatment, enzymatic saccharification, fermentation, and product recovery (Dien, 2010).

Within biochemical conversion, three common ways to convert biomass are: 1) separate hydrolysis and fermentation (SHF), 2) simultaneous saccharification and fermentation (SSF), and 3) simultaneous saccharification and co-fermentation (SSCF). After pretreatment, enzymatic hydrolysis is used to convert residual cellulose and hemicellulose into monomeric sugars. The sugars are then fermented to ethanol using yeast. When enzymatic hydrolysis and fermentation are preformed sequentially, it is referred to as SHF, when the two processes are performed simultaneously it is referred to as SSF (Ohgren et al., 2007). Studies have shown that the ethanol concentration is higher during SSF than SHF, thus reducing risk of contamination of ethanol at refineries (Ohgren et al., 2007). The conversion of cellulose and hemicellulose to monomeric sugars is harder to accomplish than conversion of starch, but conversion of lignocellulosic material is less costly (Ohgren et al., 2006). Co-fermentation of hexoses and pentoses to ethanol, referred to as SSCF, is becoming more popular in the research field in order to reduce costs associated with starch conversion (Ohgren et al., 2006).

Thermochemical conversion consists of four possible technologies—gasification, combustion, pyrolysis, or liquefaction. The two most common technologies for thermal conversion are gasification or pyrolysis (Bulushev and Ross, 2011). Gasification gives synthesis gas (syngas) which can be further processed to diesel fuel or purified to give hydrogen as a product (Bulushev and Ross 2011). Bio-oil is a liquid product of pyrolysis and can be 
catalytically converted to smaller molecules used for fuels or fuel additives (Bulushev and Ross, 2011).

\section{Study Objectives}

The objectives of this study were to determine the carbohydrate yields of switchgrass and Miscanthus cultivars using NIRS to predict theoretical ethanol yields (TEY; $\mathrm{L} \mathrm{Mg}^{-1}$ ) and ultimately theoretical ethanol production (TEP; $\mathrm{L} \mathrm{ha}^{-1}$ ) from reclaimed mine sites. Biomass from four sites was analyzed. Three sites (Alton, MeadWestvaco, and The Wilds) were used to compare TEY and TEP from switchgrass and Miscanthus; Hampshire was used to compare TEY and TEP from three switchgrass cultivars (Cave-in-Rock, Carthage, and Shawnee). Carbohydrate data were also obtained from samples sent to the National Renewable Energy Laboratory (NREL). The objective for these carbohydrate data was to compare NREL data for carbohydrate constituents to carbohydrate constituents predicted with the NIRS Consortium (NIRSC) calibrated machine at West Virginia University.

\section{Materials and Methods}

\section{Site Locations}

Compositional analysis was completed on switchgrass and Miscanthus biomass from four reclaimed mine sites described in earlier chapters (Alton, MeadWestvaco, The Wilds, and Hampshire). To analyze composition from three switchgrass cultivars (Cave-in-Rock, Shawnee, and Carthage), forage samples were collected from Hampshire. Chapter 3 provides the location and reclamation procedures for this site. To analyze composition from switchgrass and Miscanthus, forage samples were collected from Alton, MeadWestvaco, and The Wilds. Chapter 4 provides the locations and reclamation procedures for these sites. 


\section{Treatments and Experimental Designs}

In-depth descriptions of treatments and experimental designs are given in previous chapters mentioned above. Hampshire had a completely randomized design with three switchgrass cultivars replicated three times for a total of nine 0.4-ha plots. Alton had 20 0.4-ha plots with each variety of switchgrass (Kanlow and BoMaster) and Miscanthus (Public and Private) being randomly assigned to five plots. The Wilds and MeadWestvaco each had two, 0.4ha plots that were chosen for compositional analysis. One plot was switchgrass and the other was Miscanthus.

\section{Biomass Preparation for NIRS Scanning}

Switchgrass and Miscanthus biomass samples were prepared before spectroscopic analysis. Biomass was collected as described for each site in previous chapters. Biomass from clipping years 2014 and 2015 was used in the Alton analyses. Biomass from clipping year 2015 was used in The Wilds, MeadWestvaco, and Hampshire analyses. The entire biomass sample clipped within the quadrat was ground to pass a 2-mm screen of a shear (or cutting) mill (Wiley Laboratory Mill, Mod. 4, Thomas Scientific, Swedesboro, NJ 08085). A riffle splitter was used to take a sub-sample from the ground sample. The sub-sample was then ground further using a cyclone mill to pass a 1-mm screen until it had powder-like consistency. Ground subsamples were then packed into reflection mode sample cells (Tsuchikawa, 2007). Samples were packed firmly and uniformly due to the importance of a consistent packing density for accurate reflectance and spectral output (Tsuchikawa, 2007).

Sample vials were then placed on a SpectraStar 2400 RTW scanning monochromator (Unity Scientific, Brookfield, CT 06804) to collect spectral data. Spectral data were recorded as the reciprocal $\log$ of reflectance $(\log 1 / \mathrm{R})$ at $1-\mathrm{nm}$ increments over a range of $1250-2349 \mathrm{~nm}$. 
Biomass samples for Alton, MeadWestvaco, and The Wilds were also prepared using National Renewable Energy Laboratory (NREL) standards for cell wall sugar analysis (Hames et al., 2008). Samples that were previously prepared from biomass analyses were ground to pass a 2-mm screen of a shear (or cutting) mill (Wiley Laboratory Mill, Mod. 4, Thomas Scientific, Swedesboro, NJ 08085). A riffle splitter was used to take a sub-sample from the ground sample. The sub-sample was then packed into borosilicate vials and shipped to The National Renewable Energy Laboratory (NREL) for analysis of xylan, glucan, lignin, and ash using a Thermo Antaris II Fourier Transform-NIR scanner. .

\section{Calibration of Spectra}

Spectra files were standardized to a master instrument (Foss model 6500) managed by the NIRS Forage and Feed Testing Consortium (NIRSC). Equations for compositional analyses were also obtained from this consortium. The calibration equation used to predict carbohydrates was a switchgrass bioenergy equation based on samples from researchers at the USDA ARS (Vogel et

al., 2011). The samples used to create this equation were grown on agricultural sites in the Great Plains region of the USA and represent diverse varieties, locations, and harvesting techniques and timing (Vogel et al., 2011). Summary statistics for this equation developed with modified partial least squares regression are available (Vogel et al., 2011). Reference wet chemical methods for bioenergy calibration samples are also described in Vogel et al. (2011). There are multiple forage quality constituents that can be determined within this calibration. For the purposes of this study, only 13 were chosen based on the necessary components to predict ethanol yields (Table 5.1). 
Total theoretical ethanol yield was calculated from all major biomass sugars (C6 (hexose) and C5 (pentose) sugars). Prediction equations used to calculate theoretical ethanol yield are based on an assumption of 100\% ethanol conversion (Vogel et al., 2011).

Table. 5.1. Compositional traits predicted with NIRS.

\begin{tabular}{lcc}
\hline \multicolumn{1}{c}{ Variable } & Abbreviation & $\begin{array}{c}\text { Reference or } \\
\text { Equation }\end{array}$ \\
\hline $\begin{array}{l}\text { Forage Quality } \\
\text { Neutral Detergent Fiber }\end{array}$ & aNDF & NIRSC 2011 \\
$\begin{array}{l}\text { Lignin } \\
\text { Ash }\end{array}$ & LIGNIN & NIRSC 2011 \\
& ASH & NIRSC 2011 \\
Cell Wall Constituents & & \\
Arabinan & ARA & Vogel et al. (2011) \\
Xylan & XYL & Vogel et al. (2011) \\
Mannan & MAN & Vogel et al. (2011) \\
Galactan & GAL & Vogel et al. (2011) \\
Glucan & GLC & Vogel et al. (2011) \\
Sucran & SUC & Vogel et al. (2011) \\
Soluble Glucose & GLCS & Vogel et al. (2011) \\
Fructan & FRU & Vogel et al. (2011) \\
Starch & STA & Vogel et al. (2011) \\
\hline
\end{tabular}

Switchgrass and Miscanthus spectra were considered to "fit" into the calibration population structure if the mean global $\mathrm{H}$ values, or global distance (GD) values, were below 4.5. Values greater than this limit were considered outliers and were not used. If nearest distance (ND) values were above 1.7 in conjunction with a GD value greater than 4.5 , they were also considered outliers and not used. ND values show how close the individual calibration spectra points are to the individual data in question. Pentose and hexose sugar data received from NREL were compared to results predicted using the NIRSC (NIRS Consortium) equations. 


\section{Ethanol Yield Prediction}

Once spectral data were obtained, compositional analysis was used to predict theoretical ethanol yield (TEY) and theoretical ethanol production (TEP) with existing equations (Table 5.2). Method 1 included seven hexose sugars (GLC, GAL, MAN, STA, FRU, GLCS, and SUC) and two pentose sugars (XYL and ARA) to provide a comprehensive analysis to predict TEY, which included all main cell wall sugars and carbohydrates (Vogel et al., 2011). Method 2 was still considered a complete equation for TEY prediction, but it involved fewer sugars (GLC, GAL, and MAN) in the C6 TEY prediction (Dien, 2010). Method 3 included only one of each of the main hexose and pentose cell wall sugars, GLC and XYL (Dien, 2010). Initially, Method 1 was used to predict TEY and TEP at all sites due to the higher TEY prediction it made because of more hexose sugars in the Method 1 equation. During analysis of constituents used to predict TEY (Table 5.1), data for some of the less prominent hexose sugars used in Method 1 (SUC, GLCS, FRU, and STA) and not in Method 2 were found to be above the GD and ND limits, which made them outliers and suspect. An example of TEY and TEP using Method 1 for Cavein-Rock switchgrass was $445 \mathrm{~L} \mathrm{Mg}^{-1}$ and 14,037 $\mathrm{L} \mathrm{ha}^{-1}$, respectively. For Method 2, the same sample was predicted to have TEY and TEP for Cave-in-Rock switchgrass as $420 \mathrm{~L} \mathrm{Mg}^{-1}$ and 13,256 $\mathrm{L} \mathrm{ha}^{-1}$, respectively. It was decided that Method 2 was more appropriate and was therefore ultimately used in the final analysis of TEY and TEP at these four sites. Method 3, however, was used for the comparison of NREL and NIRSC TEY and TEP for Alton, MeadWestvaco, and The Wilds. This was done because the NREL and NIRSC data only included GLC and XYL, which are the sugars needed for Method 3. 
5.2. Methods and carbohydrates used in predicting theoretical ethanol yield (TEY, $\mathrm{L} \mathrm{Mg}^{-1}$ ) and theoretical ethanol production (TEP, $\mathrm{L} \mathrm{ha}^{-1}$ ) on reclaimed surface mines.

\begin{tabular}{|c|c|c|}
\hline $\begin{array}{c}\text { Method/ } \\
\text { parameter }\end{array}$ & Reference and constituents used ${ }^{\mathrm{a}}$ & Unit \\
\hline$\frac{\text { Method 1 }}{\text { HEX }}$ & $\begin{array}{l}\text { Vogel et al. }(2011) \\
(((\text { GLC+GAL+MAN }+ \text { STA }) \times 0.57)+((\text { GLCS }+ \text { FRU }) \\
\quad \times(\text { SUCx } 0.537)) \\
\quad \times 1.267 ; \text { assuming } 100 \% \text { conversion }\end{array}$ & $\mathrm{L} \mathrm{Mg}^{-1}$ \\
\hline PEN & $(\mathrm{XYL}+\mathrm{ARA}) \times 0.579 \times 1.267$ & $\mathrm{~L} \mathrm{Mg}^{-1}$ \\
\hline TEY1 & $\mathrm{HEX}+\mathrm{PEN}$ & $\mathrm{L} \mathrm{Mg}^{-1}$ \\
\hline TEP1 & TEY $1 \times$ biomass yield $\left(\mathrm{Mg} \mathrm{ha}^{-1}\right)$ & $\mathrm{L} \mathrm{ha}^{-1}$ \\
\hline Method 2 & Dien et al. (2010) & \\
\hline $\mathrm{C} 6$ & $(\mathrm{GLC}+\mathrm{GAL}+\mathrm{MAN}) \times 0.57 \times 1.267$ & $\mathrm{~L} \mathrm{Mg}^{-1}$ \\
\hline $\mathrm{C} 5$ & $(\mathrm{XYL}+\mathrm{ARA}) \times 0.579 \times 1.267$ & $\mathrm{~L} \mathrm{Mg}^{-1}$ \\
\hline TEY2 & $\mathrm{C} 6+\mathrm{C} 5$ & $\mathrm{~L} \mathrm{Mg}^{-1}$ \\
\hline TEP2 & TEY2× biomass yield $\left(\mathrm{Mg} \mathrm{ha}^{-1}\right)$ & $\mathrm{L} \mathrm{ha}^{-1}$ \\
\hline Method 3 & Dien et al. (2010) & \\
\hline GL & $\mathrm{GLC} \times 0.57 \times 1.267$ & $\mathrm{~L} \mathrm{Mg}^{-1}$ \\
\hline $\mathrm{XY}$ & $X Y L \times 0.579 \times 1.267$ & $\mathrm{~L} \mathrm{Mg}^{-1}$ \\
\hline TEY3 & $\mathrm{GL}+\mathrm{XY}$ & $\mathrm{L} \mathrm{Mg}^{-1}$ \\
\hline TEP3 & TEY3 $\times$ biomass $\left(\mathrm{Mg} \mathrm{ha}^{-1}\right)$ & $\mathrm{L} \mathrm{ha}^{-1}$ \\
\hline
\end{tabular}

${ }^{\text {a }}$ See Table 5.1

\section{Statistical Analysis}

Data were analyzed by ANOVA using PROC MIXED procedures of SAS (SAS®, Version 9.3, SAS Institute Inc., Cary, NC, Copyright @ 2002-2010) and JMP (JMP®, Version Pro 11, SAS Institute Inc., Cary, NC, Copyright (2013). Data were not transformed because the assumptions of normal distributions for ANOVA were satisfied using the Shapiro-Wilk normality test (Shapiro and Wilk, 1965). Because MWV and The Wilds had such low sample sizes per site $(\mathrm{n}=2)$, the switchgrass samples from each site were combined and analyzed together with site being the replication. The same was done for Miscanthus from each site. For each analysis, statistical significance was based on a $\mathrm{P}$ value of $<0.05$. The least square (LS) mean yields are reported. 


\section{Results and Discussion}

NIRS compositional analysis statistics for switchgrass and Miscanthus samples are

presented on a whole biomass, $\%$ dry weight basis.

\section{Hampshire}

Three switchgrass cultivars were tested at Hampshire for forage quality traits, compositional analysis, theoretical ethanol yield (TEY, $\mathrm{L} \mathrm{Mg}^{-1}$ ) and theoretical ethanol production (TEP, L ha ${ }^{-1}$ ). Hampshire biomass was not used for NREL predicted compositional analysis. Only NIRSC predicted values were used in the analyses at Hampshire (Table 5.3).

Table 5.3. Compositional values for Hampshire from switchgrass biomass samples clipped in 2015.

\begin{tabular}{lccccccccc}
\hline & \multicolumn{10}{c}{ Compositional Values } \\
\hline & ARA $^{\mathrm{a}}$ & XYL & MAN & GAL & GLC & SUC & GLCS & FRU & STA \\
\cline { 2 - 11 } Cultivar & \multicolumn{10}{c}{ \% DM } \\
CIR & 3.0 & 22.0 & 0.5 & 1.0 & 31.1 & 2.2 & 0.6 & 0.6 & 0.4 \\
Carthage & 3.0 & 21.6 & 0.5 & 1.0 & 29.6 & 2.4 & 0.5 & 0.6 & 0.5 \\
Shawnee & 3.0 & 21.7 & 0.6 & 1.0 & 30.3 & 2.5 & 0.7 & 0.7 & 0.4 \\
SE & 0.02 & 0.3 & 0.05 & 0.03 & 0.3 & 0.2 & 0.05 & 0.05 & 0.2 \\
P value & 0.3 & 0.7 & 0.2 & 0.5 & 0.06 & 0.5 & 0.1 & 0.3 & 1.0 \\
\hline
\end{tabular}

LS means are reported.

SE the Standard error of the mean

$P$ value the statistical significance by ANOVA

${ }^{\text {a }}$ See Table 5.1

Compositional analyses showed no statistically significant differences among cultivars (Table 5.3). A study done by Adler et al. (2009) found average CIR XYL contents ranged from 20.6 to $22.2 \%$, ARA ranged from $2.8 \%$ to $2.9 \%$, SUC from $2.7 \%$ to $3.0 \%$, and STA from 0.2 to 0.4\%. The results from Adler et al. (2009) were consistent with Hampshire biomass sugar results predicted from the NIRSC energy equation for the same constituents. XYL and GLC are the major fermentable sugars used for biofuel production and results from the NIRSC prediction 
equation showed average values of $21.8 \% \mathrm{DM}$ for XYL and 30.3\% DM for GLC across cultivars at Hampshire.

Table 5.4. Select forage quality traits for Hampshire

\section{Forage Quality Traits}

\begin{tabular}{cc} 
Lignin $^{\mathrm{c}}$ & Ash \\
\hline----- & \% DMDF \\
\hline-----
\end{tabular}

\section{Cultivar}

$\begin{array}{lccc}\text { CIR } & 4.8 & 3.3^{\mathrm{ab}} & 79.4 \\ \text { Carthage } & 4.6 & 4.5^{\mathrm{a}} & 75.9 \\ \text { Shawnee } & 4.9 & 2.4^{\mathrm{b}} & 78.4 \\ \text { SE } & 0.21 & 0.31 & 0.94 \\ \text { P value } & 0.6 & <0.01 & 0.08\end{array}$

${ }^{a} \overline{D i f f e r e n t ~ l e t t e r ~ d e n o t e ~ a ~ s i g n i f i c a n t ~ d i f f e r e n c e ~ a t ~} \mathrm{p}<0.05$ level of probability. LS means are reported.

SE the Standard error of the mean

'See Table 5.1

Results for forage quality traits show that there was a significant difference among cultivars for ash content (Table 5.4). Ash content of Carthage and CIR were not significantly different, but Carthage and Shawnee differed. Low ash content in the feedstock is important for making it more acceptable for use for combustion endpoints (McLaughlin et al., 1999). The reduction in ash content can also be attributed to increasing proportions of stem relative to leaf mass later in the growing season (McLaughlin et al., 1999). Other forage quality traits tested were not significantly different among cultivars (Table 5.4). 
Table 5.5. Theoretical yield (TEY, $\mathrm{L} \mathrm{Mg}^{-1}$ ) and production (TEP, $\mathrm{L} \mathrm{ha}^{-1}$ ) of ethanol from Hampshire for biomass clippings in year 2015 using the Method 2 prediction equation (Dien et al., 2010).

\section{Theoretical Ethanol Yield and Production}

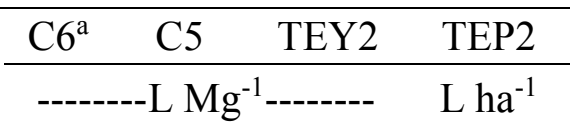

\section{Cultivar}

$\begin{array}{lllll}\text { CIR } & 235 & 183 & 420 & 13,274\end{array}$

Carthage $224 \quad 180 \quad 405 \quad 5,623$

Shawnee $\quad \begin{array}{llll}230 & 181 & 412 & 17,502\end{array}$

$\begin{array}{lllll}\mathrm{SE} & 2.4 & 2.5 & 4.3 & 3,476\end{array}$

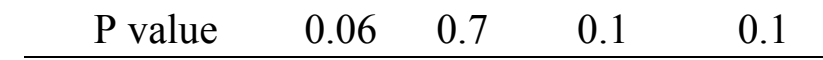

Least square (LS) means are reported.

SE the Standard error of the mean

$P$ value the statistical significance by ANOVA

${ }^{\text {a }}$ See Table 5.1

The Method 2 prediction equation incorporated fewer sugars in the C6 prediction. There were no significant differences for C6, C5, TEY2, or TEP2 among cultivars using this equation (Table 5.5). Because biomass clippings from 2015 were only used in predictions, Shawnee had higher TEP2 yields than CIR. CIR is commonly known to produce higher biomass yields, thus increasing TEP yields (Brown et al., 2014), but in 2015, biomass yield was higher for Shawnee.

\footnotetext{
Alton

Compositional analyses showed significant differences for species in all cell wall constituents (ARA, XYL, MAN, GAL, GLC, SUC, GLCS) except FRU (Table 5.6). Switchgrass and Miscanthus are both warm-season perennial grass species, which suggests that there should be similarities between the carbohydrate yields. Even though differences among species are significant, values for most sugars vary by \pm 0.05 to $1.0 \%$. GLC for switchgrass is lower than Miscanthus, but Miscanthus XYL is less than switchgrass.
} 
Table 5.6. Sugar Composition for biomass clippings from 2014 and 2015 from Alton.

\section{Cell Wall Constituents}

\begin{tabular}{|c|c|c|c|c|c|c|c|}
\hline $\mathrm{ARA}^{\mathrm{a}}$ & XYL & MAN & GAL & GLC & SUC & $\begin{array}{c}\text { GLC } \\
\text { S }\end{array}$ & FRU \\
\hline
\end{tabular}

Species

$\begin{array}{lcccccccc}\text { Switchgrass } & 2.9 & 26.6 & 0.3 & 1.0 & 34.6 & 0.9 & 0.1 & 0.1 \\ \text { Miscanthus } & 3.4 & 25.1 & 0.1 & 0.8 & 35.4 & 2.0 & 0.5 & 0.1 \\ \text { SE } & 0.23 & 0.08 & 0.12 & 0.09 & 0.33 & 0.55 & 0.2 & 0.001 \\ \text { P value } & <0.01 & <0.01 & <0.01 & <0.01 & <0.01 & <0.01 & <0.01 & 0.9\end{array}$

Species (Cultivar)

Switchgrass

$\begin{array}{lcccccccc}\text { Kanlow } & 3.5 & 26.7 & 0.3 & 1.0 & 34.6 & 0.8 & 0.1 & 0.02 \\ \text { BoMaster } & 3.3 & 26.4 & 0.3 & 1.0 & 34.6 & 1.0 & 0.1 & 0.1 \\ \text { SE } & 0.03 & 0.19 & 0.02 & 0.01 & 0.07 & 0.09 & 0.03 & 0.02 \\ \text { P value } & 0.3 & 0.4 & 0.7 & 0.4 & 0.8 & 0.7 & 0.7 & 0.3\end{array}$

Miscanthus

$\begin{array}{lcccccccc}\text { Public } & 2.9 & 24.7 & 0.1 & 0.8 & 35.5 & 1.8 & 0.6 & 0.1 \\ \text { Private } & 3.1 & 25.6 & 0.8 & 0.8 & 35.4 & 2.2 & 0.4 & 0.02 \\ \text { SE } & 0.06 & 0.49 & 0.02 & 0.02 & 0.06 & 0.21 & 0.09 & 0.05 \\ \text { P value } & 0.1 & 0.04 & 0.5 & 0.2 & 0.4 & 0.4 & 0.2 & 0.1\end{array}$

Year

\begin{tabular}{lcccccccc}
2014 & 3.2 & 26 & 0.2 & 0.9 & 35.6 & 1.4 & 0.2 & 0.05 \\
2015 & 3.2 & 25.7 & 0.2 & 0.9 & 34.4 & 1.5 & 0.4 & 0.08 \\
SE & 0.19 & 0.45 & 0.07 & 0.05 & 0.33 & 0.32 & 0.13 & 0.04 \\
P value & 0.2 & 0.2 & $<0.01$ & 0.2 & $<0.01$ & 0.6 & 0.05 & 0.4 \\
\hline
\end{tabular}

LS means are reported.

SE the Standard error of the mean

$P$ value the statistical significance by ANOVA

${ }^{\text {aS }}$ See Table 5.1

There was no cultivar within species interactions for carbohydrate constituents between switchgrass cultivars Kanlow and BoMaster (Table 5.6). XYL content of Public Miscanthus was less than that for Private Miscanthus (Table 5.6). XYL, ARA, GAL, SUC, and FRU were not significant for years 2014 and 2015 for all biomass averaged together (Table 5.6). MAN, GLC, and GLCS content differed significantly between years 2014 and 2015 (Table 5.6). 
Forage quality traits such as lignin and ash did not differ significantly between switchgrass and Miscanthus (Table 5.7). Neutral detergent fiber was significantly higher in Miscanthus than switchgrass ( 87.5 and $86.2 \%$ DM, respectively). There was no significant difference between switchgrass cultivars Kanlow and BoMaster for forage quality traits (Table 5.7), but there was a significant difference between Public and Private Miscanthus for lignin (6.0 and $4.9 \%$, respectively). There was also a significant difference for lignin and aNDF between years 2014 and 2015 when species were averaged together.

Table 5.7. Forage quality traits for biomass clippings from years 2014 and 2015 from Alton

Forage Quality Traits

\begin{tabular}{ccccc}
\hline \multirow{4}{*}{ Species } & & Lignin & Ash & aNDF \\
\cline { 3 - 5 } & & ---- & \% DM & ---- \\
& Switchgrass & 5.0 & 4.5 & 86.2 \\
& Miscanthus & 5.5 & 4.6 & 87.5 \\
SE & 0.24 & 0.19 & 0.66 \\
P value & 0.09 & 0.8 & 0.03 \\
Cultivar(Species) & & & \\
Switchgrass & & & \\
Kanlow & 5.0 & 4.4 & 86.4 \\
BoMaster & 5.1 & 4.6 & 85.9 \\
SE & 0.15 & 0.20 & 0.6 \\
P value & 0.8 & 0.7 & 0.4
\end{tabular}

Miscanthus

$\begin{array}{lccc}\text { Public } & 6.0 & 5.0 & 87.3 \\ \text { Private } & 4.9 & 4.1 & 87.7 \\ \text { SE } & 0.24 & 0.25 & 0.4 \\ \text { P value } & 0.04 & 0.2 & 0.9\end{array}$

Year

$\begin{array}{lll}\text { P value }-0.2 & 0.9\end{array}$

\begin{tabular}{lccc}
2014 & 4.9 & 4.5 & 88.2 \\
2015 & 5.7 & 4.7 & 85.3 \\
SE & 0.29 & 0.18 & 0.75 \\
P value & $<0.01$ & 0.4 & $<0.01$ \\
\hline
\end{tabular}

LS means are reported.

SE the Standard error of the mean 
$P$ value the statistical significance by ANOVA

${ }^{\text {a }}$ See Table 5.1

There was no significant difference in C6 sugars between switchgrass and Miscanthus using Method 2 (Table 5.8). There was a significant difference between switchgrass and Miscanthus for C5 sugars (Table 5.8.). Miscanthus produced significantly less C5 sugars than switchgrass (209 $\mathrm{L} \mathrm{Mg}^{-1}$ and $216 \mathrm{~L} \mathrm{Mg}^{-1}$, respectively). There was no significant difference between Miscanthus and switchgrass TEP2 (Table 5.8). Comparing switchgrass cultivars, Kanlow and BoMaster, there were no significant differences. Miscanthus varieties, Public and Private, were significantly different for C5 sugars with the Private variety having $211 \mathrm{~L} \mathrm{Mg}^{-1} \mathrm{C} 5$ and the Public having $202 \mathrm{~L} \mathrm{Mg}^{-1} \mathrm{C}$. When species and cultivars were averaged together for 2014 and 2015, there were significant differences recorded for C6 and TEY2 (Table 5.8). In 2014, C6 sugars and TEY2 were significantly higher than in 2015 (Table 5.8). 
Table 5.8. Theoretical ethanol yield (TEY, $\mathrm{L} \mathrm{Mg}^{-1}$ ) and Theoretical ethanol production (TEP, $\mathrm{L} \mathrm{ha}^{-1}$ ) from Method 2 for biomass clippings from 2014 and 2015 from Alton.

Theoretical Ethanol Yield and Production

\begin{tabular}{lcccc}
\hline & $\mathrm{C6}^{\mathrm{a}}$ & $\mathrm{C} 5$ & $\mathrm{TEY} 2$ & $\mathrm{TEP} 2$ \\
\cline { 2 - 5 } Species & ------- & $\mathrm{L} \mathrm{Mg}^{-1}$ & ------ & $\mathrm{L} \mathrm{ha}^{-1}$ \\
$\quad$ Switchgrass & 259 & 216 & 479 & 4,261 \\
$\quad$ Miscanthus & 266 & 209 & 467 & 5,423 \\
$\quad$ SE & 1.6 & 2.6 & 0.27 & 581 \\
$\quad$ P value & 0.09 & $<0.01$ & $<0.01$ & 0.4 \\
Cultivar & & & & \\
$\quad$ Kanlow & 259 & 221 & 481 & 4,712 \\
$\quad$ BoMaster & 259 & 218 & 477 & 3,809 \\
SE & 2.1 & 3.5 & 2.1 & 661 \\
P value & 0.6 & 0.3 & 0.4 & 0.6 \\
& & & & \\
$\quad$ Public & 263 & 202 & 464 & 5,127 \\
$\quad$ Private & 267 & 211 & 472 & 5,794 \\
SE & 2.4 & 3.8 & 4.2 & 896 \\
$\quad$ P value & 0.7 & 0.03 & 0.2 & 0.8 \\
Year & & & & \\
2014 & 267 & 214 & 479 & 4,934 \\
2015 & 256 & 212 & 468 & 4,621 \\
SE & 1.9 & 2.1 & 3.7 & 156.8 \\
P value & $<0.01$ & 0.2 & 0.01 & 0.7 \\
\hline
\end{tabular}

LS means are reported.

SE the Standard error of the mean

$P$ value the statistical significance by ANOVA

${ }^{\text {a See Table } 5.1}$

\section{The Wilds and MeadWestvaco}

Switchgrass and Miscanthus were significantly different for all cell wall constituents (Table 5.9). ARA for switchgrass averaged 3.2\% DM while Miscanthus averaged only 3.0\% DM. XYL and GLC were both higher for switchgrass, XYL being $23.6 \%$ for switchgrass and $20.5 \%$ for Miscanthus. GLC average for switchgrass was 31.6\% DM and 29\% DM for Miscanthus. Lignin, ash, and aNDF were all significantly different between switchgrass and Miscanthus (Table 5.10). Lignin and aNDF were significantly higher for switchgrass than 
Miscanthus (Table 5.10). Ash was significantly higher for Miscanthus than switchgrass (6.7 L $\mathrm{Mg}^{-1}$ and 4.5 $\mathrm{L} \mathrm{Mg}^{-1}$, respectively).

Table 5.9. Compositional values for switchgrass and Miscanthus biomass clippings from 2015 from MWV and The Wilds.

\begin{tabular}{|c|c|c|c|c|c|c|c|c|c|}
\hline & \multicolumn{9}{|c|}{ Cell Wall Constituents } \\
\hline & ARA $^{a}$ & $\mathrm{XYL}$ & MAN & GAL & GLC & SUC & GLCS & FRU & STA \\
\hline \multicolumn{10}{|l|}{ Species } \\
\hline Switchgrass & 3.2 & 23.6 & 0.4 & 1.0 & 31.6 & 1.8 & 0.5 & 0.4 & 0.0 \\
\hline Miscanthus & 3.0 & 20.5 & 0.3 & 0.92 & 29.0 & 3.6 & 1.3 & 1.4 & 0.3 \\
\hline SE & 0.07 & 0.5 & 0.08 & 0.03 & 0.5 & 0.3 & 0.03 & 0.12 & 0.3 \\
\hline$P$ value & $<0.01$ & $<0.01$ & $<0.01$ & $<0.01$ & $<0.01$ & $<0.01$ & $<0.01$ & $<0.01$ & $<0.01$ \\
\hline
\end{tabular}

LS means are reported.

SE the Standard error of the mean

$P$ value the statistical significance by ANOVA

${ }^{\text {a }}$ See Table 5.1

Table 5.10. Forage quality traits for switchgrass and Miscanthus biomass clippings from 2015 for MWV and The Wilds.

\section{Forage Quality Traits}

\begin{tabular}{ccc} 
Lignin $^{\mathrm{a}}$ & Ash & aNDF \\
\hline---- & $\%$ DM -----
\end{tabular}

\section{Species}

\begin{tabular}{lccc} 
Switchgrass & 4.7 & 4.5 & 79.5 \\
Miscanthus & 3.7 & 6.7 & 71.7 \\
SE & 0.1 & 0.4 & 1.0 \\
P value & $<0.01$ & $<0.01$ & $<0.01$ \\
\hline
\end{tabular}

LS means are reported.

SE the Standard error of the mean

$P$ value the statistical significance by ANOVA

${ }^{\text {aSee Table }} 5.1$

C6, C5, TEY2, and TEP2 for switchgrass at MWV and The Wilds were averaged together and Miscanthus from MWV and The Wilds were averaged together with site as replication for this analysis (Table 5.11). There were significant differences between switchgrass and Miscanthus for all parameters. C6 sugars were significantly higher for switchgrass than 
Miscanthus (238 $\mathrm{L} \mathrm{Mg}^{-1}$ and $219 \mathrm{~L} \mathrm{Mg}^{-1}$ ). C5 sugars were also significantly higher for switchgrass than Miscanthus (Table 5.11). TEY2 and TEP2 were significantly higher for switchgrass than Miscanthus (Table 5.11). Because of poor stand establishment and weed competition at both sites, switchgrass is growing better and is producing significantly higher biomass yields than Miscanthus, which translated into higher TEY2 and greater TEP2.

Table 5.11. Theoretical ethanol yield (TEY, $\mathrm{L} \mathrm{Mg}^{-1}$ ) and theoretical ethanol production (TEP, $\mathrm{L} \mathrm{ha}^{-1}$ ) for Method 2 for switchgrass and Miscanthus biomass clipped from 2015 from MWV and The Wilds.

Theoretical Ethanol Yield and Production

\begin{tabular}{cccc}
$\mathrm{C6}^{\mathrm{a}}$ & $\mathrm{C} 5$ & $\mathrm{TEY} 2$ & $\mathrm{TEP} 2$ \\
\hline ---- & $\mathrm{L} \mathrm{Mg}^{-1}$ & --- & $\mathrm{L} \mathrm{ha}^{-1}$
\end{tabular}

\section{Species}

\begin{tabular}{llccc} 
Switchgrass & 238 & 197 & 434 & 3,579 \\
Miscanthus & 219 & 172 & 392 & 1,353 \\
SE & 3.4 & 3.9 & 5.2 & 1,346 \\
P value & 0.03 & 0.03 & $<0.01$ & $<0.01$ \\
\hline
\end{tabular}

LS means are reported.

SE the Standard error of the mean

$P$ value the statistical significance by ANOVA

${ }^{\text {aS }}$ See Table 5.1

\section{NREL and NIRSC}

GLC and XYL results received from the National Renewable Energy Laboratory (NREL) were used to predict TEY3 and TEP3 using Method 3 from Dien et al. (2010). This equation uses only GLC and XYL to predict TEY3. Results from NREL were also compared to results from Alton and The Wilds/MWV NIRSC GLC and XYL results to predict TEY3 (Table 5.12).

Significant differences were seen for GLC and XYL for switchgrass samples analyzed from NREL and NIRSC. NREL predicted higher GLC values than NIRSC (37.4\% and 34.6\% DM, respectively). NIRSC predicted higher XYL than NREL for switchgrass $(26.6 \%$ and $24.5 \%$ DM, respectively). There was no significant difference between NREL and NIRSC for TEY3 or 
TEP3. For NREL and NIRSC analysis for Miscanthus, there was a significant difference observed for GLC, XYL, and TEY3 (Table 5.12). NREL predicted significantly higher values for GLC and TEY3, but NIRSC predicted significantly higher values for XYL for Miscanthus (Table 5.12). There was no significant difference between NREL and NIRSC for Miscanthus TEP3 (Table 5.12). Results for analysis done on species averaged across years showed that there was a significant difference between NREL and NIRSC for GLC, XYL, and TEY3 (Table 5.12). Year 2014 was significantly higher in all values except TEP3, where results were not significant.

Also analyzed within Table 5.12 were the results for switchgrass and Miscanthus averages from The Wilds and MWV. NREL predicted significantly higher results for GLC and TEY3 than NIRSC (Table 5.12). GLC for switchgrass predicted by NREL was $36.3 \mathrm{~L} \mathrm{Mg}^{-1}$ and 31.6 $\mathrm{L} \mathrm{Mg}^{-1}$ for NIRSC switchgrass. XYL was significantly higher for switchgrass predicted by NIRSC than NREL (23.6 and $22.0 \mathrm{~L} \mathrm{Mg}^{-1}$, respectively). TEP3 was not significantly different between NREL and NIRSC for switchgrass. Miscanthus NREL predictions were significantly higher for GLC and TEY3 than NIRSC (Table 5.12). GLC values for Miscanthus were $35.0 \mathrm{~L}$ $\mathrm{Mg}^{-1}$ for NREL and 29.0 L Mg${ }^{-1}$ for NIRSC. XYL was significantly higher for Miscanthus by NIRSC than NREL (Table 5.12). TEP3 was not significant. 
Table 5.12. Carbohydrate constituents, theoretical ethanol yield (TEY, $\mathrm{L} \mathrm{Mg}^{-1}$ ) and theoretical ethanol production (TEP, $\mathrm{L} \mathrm{ha}^{-1}$ ) from biomass clippings from 2014 and 2015 from Alton and from 2015 from MWV and The Wilds comparing NREL and NIRSC.

\begin{tabular}{|c|c|c|c|c|}
\hline Alton & GLC & XYL & TEY3 & TEP3 \\
\hline Switchgrass & ---- $\%$ & $\Lambda$---- & $\mathrm{L} \mathrm{Mg}^{-1}$ & $\mathrm{~L} \mathrm{ha}^{-1}$ \\
\hline NREL & 37.4 & 24.5 & 449 & 4,000 \\
\hline NIRSC & 34.6 & 26.6 & 445 & 3,961 \\
\hline SE & 0.3 & 0.23 & 2.3 & 429 \\
\hline$P$ value & $<0.01$ & $<0.01$ & 0.1 & 1.0 \\
\hline
\end{tabular}

Miscanthus

$\begin{array}{lcccc}\text { NREL } & 40.3 & 22 & 453 & 5,638 \\ \text { NIRSC } & 35.5 & 25.1 & 439 & 5,053 \\ \text { SE } & 0.4 & 0.29 & 1.8 & 450 \\ \text { P value } & <0.01 & <0.01 & <0.01 & 0.6\end{array}$

Year

$\begin{array}{lcccc}2014 & 37.8 & 25.0 & 455 & 4,794 \\ 2015 & 36.3 & 23.2 & 438 & 4,515 \\ \mathrm{SE} & 0.6 & 0.46 & 3.0 & 317 \\ \mathrm{P} \text { value } & <0.001 & <0.01 & <0.01 & 0.6\end{array}$

\section{MWV-Wilds}

Switchgrass

$\begin{array}{lcccc}\text { NREL } & 36.3 & 22.0 & 424 & 3501 \\ \text { NIRSC } & 31.6 & 23.6 & 401 & 1243 \\ \text { SE } & 0.5 & 0.2 & 4.4 & 644 \\ \text { P value } & <0.01 & <0.01 & <0.01 & 0.08\end{array}$

Miscanthus

\begin{tabular}{lcccc} 
NREL & 35.0 & 19.0 & 391 & 1336 \\
NIRSC & 29.0 & 20.5 & 360 & 3311 \\
SE & 0.5 & 0.2 & 4.4 & 644 \\
P value & $<0.01$ & $<0.01$ & $<0.01$ & 0.08 \\
\hline
\end{tabular}

LS means are reported.

SE the Standard error of the mean

$P$ value the statistical significance by ANOVA

${ }^{\text {a }}$ See Table 5.1

\section{Conclusion}

Switchgrass and Miscanthus have been studied as potential alternatives to current energy sources for theoretical ethanol yield and production. Both have been evaluated in this study for TEY and TEP on reclaimed surface mines. Values of specific carbohydrate constituents used in 
the fermentation process to fuel have been identified and compared among cultivars and between both species. For biomass of three cultivars of switchgrass (CIR, Shawnee, and Carthage) at Hampshire, no statistical differences were detected for compositional analysis, TEY, or TEP in our study. For switchgrass and Miscanthus at Alton, there were no significant differences between major sugars used in fermentation for these two species. At MWV and The Wilds, switchgrass produced significantly higher contents of XYL and GLC, two main fermentable sugars, than Miscanthus. There were significant differences found at Alton between species for compositional values but not within cultivars. Switchgrass produced higher TEY2 than

Miscanthus and there were rarely significant differences found between species for TEP2. Switchgrass at MWV/Wilds produced significantly higher TEY2 and TEP2, but this is because Miscanthus plants did not perform well and had much lower biomass yields at both of these sites than swtichgrass. When comparing NREL to NIRSC analyses using Method 3 (only GLC and XYL sugars), NREL typically predicted higher TEY3 yields based on higher GLC and XYL. It is important to be aware that these ethanol yields are assuming $100 \%$ conversion efficiency. These yields do not factor in large-scale commercial ethanol plants and the issues that face conversion rates and efficiency.

\section{Literature Cited}

Adler, P.R., M.A. Sanderson, A.A. Boateng, P.J. Weimer, and H.G. Jung. 2006. Biomass yield and biofuel quality of switchgrass harvested in fall or spring. Agron. J. 98: 1518-1525.

Adler, P.R., M.A. Sanderson, P.J. Weimer, and K.P. Vogel. 2009. Plant species composition and biofuel yields of conservation grasslands. Eco. App. 19: 2202-2209. 
Brown, C. 2014. Biomass production, composition, and ethanol potential of switchgrass grown on reclaimed surface mines in West Virginia. M.S. Thesis, West Virginia Univ., West Virginia.

Bulushev, D. and J.R.H. Ross. 2011. Catalysis for conversion of biomass to fuels via pyrolysis and gasification: A review. Catalysis Today 171: 1-13.

Corson, D.C., G.C. Waghorn, M.J. Ulyatt, and J. Lee. 1999. NIRS: Forage analysis and livestock feeding. Proceedings New Zealand Grassland Assoc. 61: 127-132.

David, K., and A.J. Ragauskas. 2010. Switchgrass as an energy crop for biofuel production: A review of its lingo-cellulosic chemical properties. Energy Environ. Sci. 3: 1182-1190.

Dien, B.S. 2010. Mass balances and analytical methods for biomass pretreatment experiments. P. 213-231. In: Vertes AA, Qureshi N, Blaschek HP, Yukawa H (eds) Biomass to biofuels: strategies for global industries. Blackwell Publishing Ltd, Oxford. doi:10.1002/ 9780470750025

Dwivedi, P., J.R.R. Alavalapati, and P. Lal. 2009. Cellulosic ethanol production in the United States: conversion technologies, current production status, economics, and emerging developments. Energy Sustainable Develop. 13: 174-182.

Fahmi R., A.V. Bridgwater, L.I. Darvell, J.M. Jones, N. Yates, S.Thain, I.S. Donnison. 2007. The effect of alkali metals on combustion and pyrolysis of Lolium and Festuca grasses, switchgrass and willow. Fuel 86: 1560-1569.

Gray K.A., L. Zhao, and M. Emptage. 2006. Bioethanol. Chemical Biology 10: 141-146.

Hames, B.R., S.R. Thomas, A.D. Sluiter, C.J. Roth, and D.W. Templeton. 2003. Rapid biomass analysis. Applied Biochem. Botech. 105-108: 5-16. 
Han, M., G.W. Choi, Y. Kim, and B.C. Koo. 2011. Bioethanol production by Miscanthus as a lignocellulosic biomass: Focus on high efficiency conversion to glucose and ethanol. Biores, 6: 1939-1953.

Huber G.W., S. Iborra, and A. Corma. 2006. Synthesis of transportation fuels from biomass: chemistry, catalysts, and engineering. Chem. Rev. 106: 4044-4098.

Jiang, Y., Y. Yuan, and Y. Wang. 2012. Physiological response, cell wall constituents, and gene expression of switchgrass under short-term drought stress and recovery. Crop Sci. 52: 2718-2727.

JMP®, Version Pro 11. SAS Institute Inc., Cary, NC, 1989-2007.

Lee J. 1997. Biological conversion of lignocellulosic biomass to ethanol. J. Biotech. 56: 1-24.

McClure, W.F., and S. Tsuchikawa. 2007. Instruments. In: Y. Ozaki, W.F. McClure, A.A. Christy, editors, Near-Infrared Spectroscopy in Food Science and Technology. John Wiley \& Sons, Hoboken, NJ. p. 75-108.

McLaughlin, S., J. Bouton, D. Bransby, B. Conger, W. Ocumpaugh, D. Parrish, C. Taliaferro, K. Vogel, and S. Wullschleger. 1999. Developing switchgrass as a bioenergy crop. p. 282299. In: Perspectives on New Crops and New Uses. J. Janick (ed), ASHS Press, Alexandria, VA.

Monono, E.M., P.E. Nyren, M.T. Berti, and S.W. Pryor. 2013. Variability in biomass yield, chemical composition, and ethanol potential of individual and mixed herbaceous biomass species grown in North Dakota. Ind. Crops Prod, 41: 331-339. 
Murray, I. 1986. The NIR spectra of homologous series of organic compounds. pp. 13-28. In: Hollo, J., K.J. Kaffaka, and J.L. Gonczy. (eds). Near Infrared Diffuse Reflectance/Transmittance Spectroscopy. Budapest: Akademiai Kiado.

Murray, I. 1993. Forage analysis by near infra-red spectroscopy. p. 285-312. In: A. Davies et al. (ed.) Sward Measurement Book. The British Grassland Society. Reading, Berks.

Norris, K.H., R.P. Barnes, J.E. Moore, and J.S. Shenk. 1976. Predicting forage quality by infrared reflectance spectroscopy. J. Anim. Sci. 43: 889-897.

National Renewable Energy Laboratory. 2016. Standard procedures for biomass compositional analysis. [Online]. Available at http://www.nrel.gov/biomass/analytical_procedures.html (accessed 4 April 2016).

Ohgen, K., O. Bengtsson, M.F. Gorwa-Grauslund, M. Galbe, B. Hahn-Hagerdal, and G. Zacchi. 2006. Simultaneous saccharification and co-fermentation of glucose and xylose in steampretreated corn stover at high fiber content with Saccharomyces cerevisiae TMB3400. J. Biotech. 126: 488-498.

Ohgren, K., R. Bura, G. Lesnicki, J. Saddler, and G. Zacchi. 2007. A comparison between simultaneous saccharification and fermentation and separate hydrolysis and fermentation using steam-pretreated corn stover. Process Biochem. 42: 834-839.

Statistical Analysis System. 2011. SAS/STAT systems for windows v.9.3. SAS Institute, Cary, N.C.

Schmer, M.R., K.P. Vogel, R.B. Mitchell, B.S. Dien, H.G. Jung, and M.D. Casler. 2012. Temporal and spatial variation in switchgrass biomass composition and theoretical ethanol yield. Agron. J. 104: 54-64. 
Shapiro, S. S. and M.B. Wilk. 1965. An analysis of variance test for normality (complete samples). Biometrika. 52: 591-611.

Sluiter, A.; Sluiter, J.; Wolfrum, E. J. (2013). Chapter 8: Methods for Biomass Compositional Analysis. Behrens, M. and Dayte, A. K., (eds.), Catalysis for the Conversion of Biomass and Its Derivatives. Max Plank Research Library for the History and Development of Knowledge, Proceedings 2. Berlin, Germany: Edition Open Access pp. 213-254; NREL Report No. CH-5100-51027

Tsuchikawa, S. 2007. Sampling Techniques. p. 133-144. In: Y. Ozaki, W.F. McClure, A.A. Christy, (eds.), Near-Infrared Spectroscopy in Food Science and Technology. John Wiley \& Sons, Hoboken, NJ.

Vogel, K.P., B.S. Dien, H.G. Jung, M.D. Casler, S.D. Masterson, and R.B. Mitchell. 2011. Quantifying actual and theoretical ethanol yields for switchgrass strains using NIRS analyses. Bioenerg. Res. 4: 96-110.

Williams, P. 2007. Grains and Seeds. p. 165-218. In: Y. Ozaki, W.F. McClure, A.A. Christy, editors, Near-Infrared Spectroscopy in Food Science and Technology. John Wiley \& Sons, Hoboken, NJ. 